Prepared in cooperation with the Yakama Nation Fisheries Program

\title{
Fish and Habitat Assessment in Rock Creek, Klickitat County, Washington, 2016-17
}

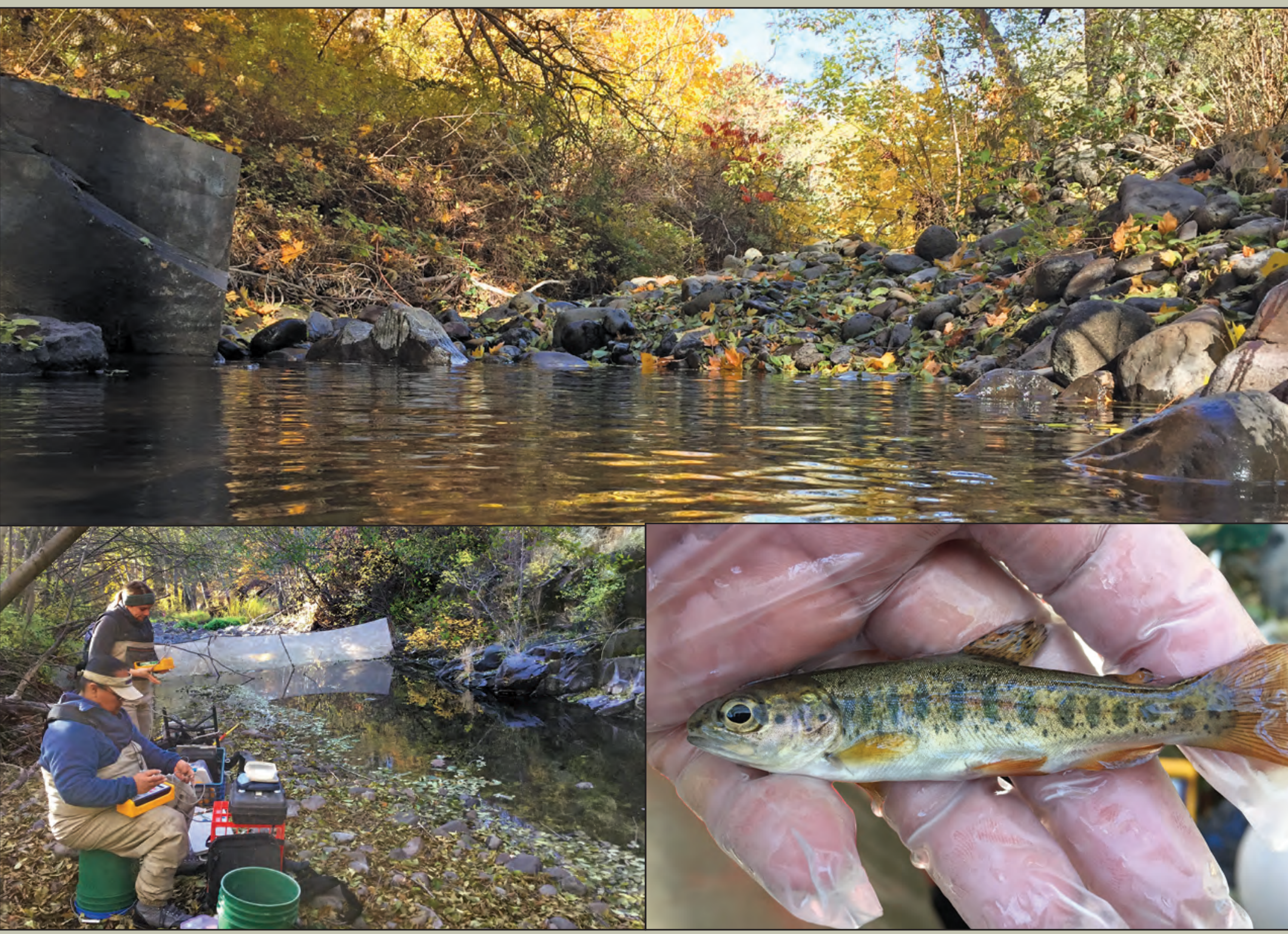

Open-File Report 2019-1092

U.S. Department of the Interior

U.S. Geological Survey 
Cover: Front cover photographs, clockwise from top: Rock Creek, southeastern Washington (Elaine Harvey, Yakama Nations Fisheries, October 16, 2017); Oncorhychus mykiss captured during electroshocking in Rock Creek, Southeastern, Washington (Elaine Harvey, Yakama Nations Fisheries, October 26, 2017); U.S. Geological Survey and Yakama Nation Fisheries personnel setting up fish-tagging station at Rock Creek, Washington (Jill Hardiman, U.S. Geological Survey, October 26, 2017). 


\section{Fish and Habitat Assessment in Rock Creek, Klickitat County, Washington, 2016-17}

By Jill M. Hardiman and Elaine Harvey

Prepared in cooperation with the Yakama Nation Fisheries Program

Open-File Report 2019-1092

U.S. Department of the Interior

U.S. Geological Survey 


\section{U.S. Department of the Interior \\ David Bernhardt, Acting Secretary}

\section{U.S. Geological Survey James F. Reilly, Director}

U.S. Geological Survey, Reston, Virginia: 2019

For more information on the USGS-the Federal source for science about the Earth, its natural and living resources, natural hazards, and the environment-visit http://www.usgs.gov/ or call 1-888-ASK-USGS (1-888-275-8747).

For an overview of USGS information products, including maps, imagery, and publications, visit http://www.usgs.gov/pubprod/.

Any use of trade, firm, or product names is for descriptive purposes only and does not imply endorsement by the U.S. Government.

Although this information product, for the most part, is in the public domain, it also may contain copyrighted materials as noted in the text. Permission to reproduce copyrighted items must be secured from the copyright owner.

Suggested citation:

Hardiman, J.M., and Harvey, Elaine, 2019, Fish and habitat assessment in Rock Creek, Klickitat County, Washington 2016-17: U.S. Geological Survey Open-File Report 2019-1092, 67 p., https://doi.org/10.3133/ofr20191092.

ISSN 2331-1258 (online) 


\section{Table of Contents}

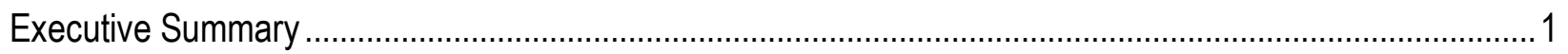

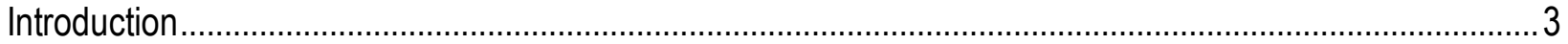

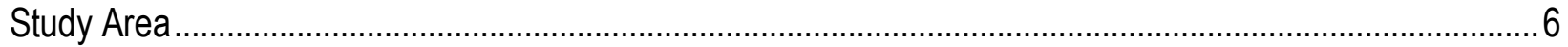

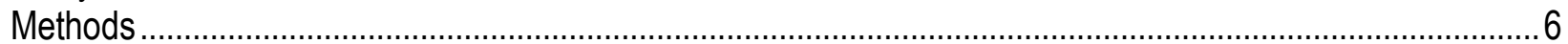

Stream Pool Habitat Surveys ...........................................................................................................

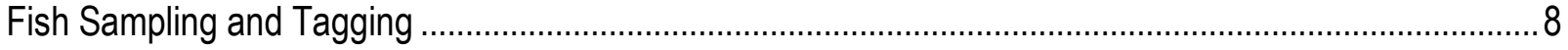

Pool Population Estimates and Condition Factor ................................................................................

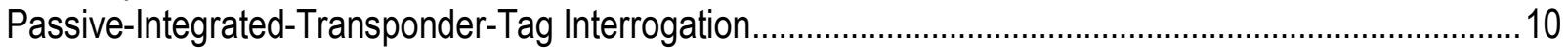

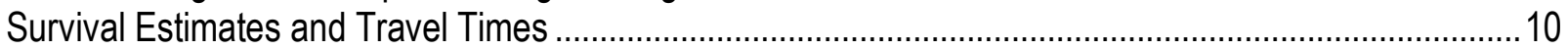

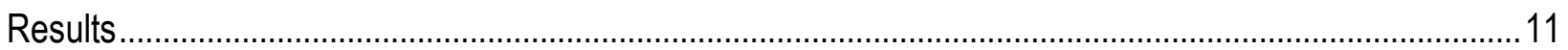

Stream Pool Habitat Surveys ..................................................................................................... 11

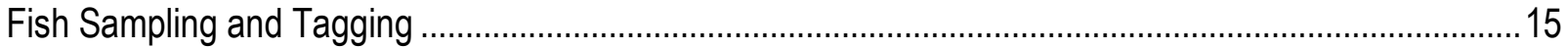

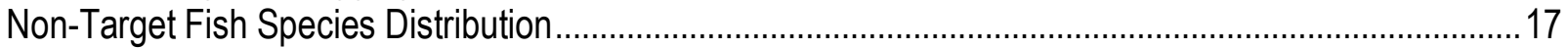

Pool Population Estimates …………………………………………………………………....... 18

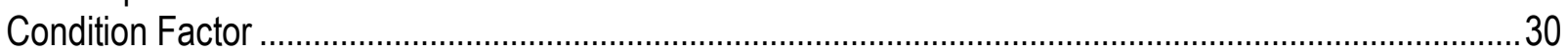

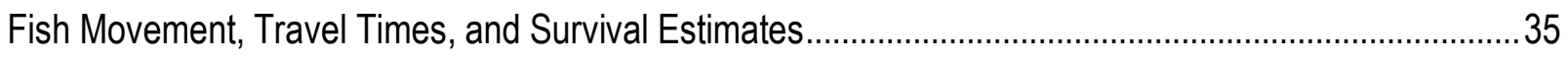

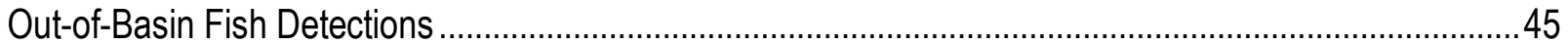

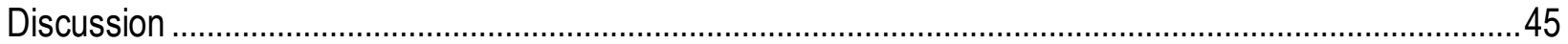

Adaptive Management and Lessons Learned ....................................................................................50

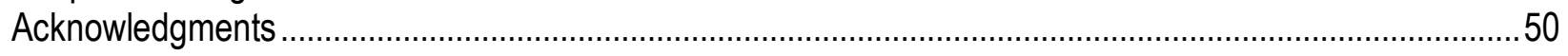

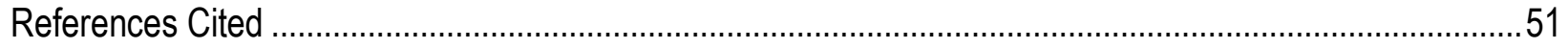

Appendix 1.Length Frequency Histograms.....................................................................................5

Appendix 2.Weight-Length Relationships .......................................................................................64

Appendix 3. PIT-Tag Interrogation System Operation Log ....................................................................67

\section{Figures}

Figure 1. Map showing the Rock Creek subbasin and locations of tributary streams and passiveintegrated-transponder-tag interrogation systems Rock Creek Squaw and Rock Creek Longhouse in Rock Creek, Washington.

Figure 2. Schematic of Rock Creek and Walaluuks Creek, Washington showing the location and streambed sections that were non-pool dry, non-pool wet, and pool habitats during surveys in late August to September, 2016 and 2017.

Figure 3. Schematic of Rock Creek and Walaluuks Creek, Washington showing the location and streambed sections that were non-pool dry, non-pool wet, and pool habitats during surveys in late August to September, and pool abundance estimate locations sampled during 2016 and 2017.

Figure 4. Graphs showing the number of age- 0 and age- 1 or older (fork length greater than 110 millimeter) Oncorhynchus mykiss per square meter during autumn 2016 and 2017 in Rock Creek, Washington .........21 Figure 5. Graphs showing the number of age-0 and age-1 or older Oncorhynchus mykiss per square meter during autumn 2016 and 2017 in Walaluuks Creek, Washington.

Figure 6. Graphs showing the number of Coho salmon per square meter during autumn 2016 and 2017 in Rock Creek, Washington.

Figure 7. Graphs showing the number of Coho salmon per square meter during autumn 2016 and 2017 in Walaluuks Creek, Washington. 
Figure 8. Graphs showing the number of bridgelip sucker per square meter during autumn 2016 and 2017 in Rock Creek, Washington ...................................................................................................26

Figure 9. The number of bridgelip sucker per square meter during autumn 2017 in Walaluuks Creek, Washington. 27

Figure 10. Graphs showing pool population abundance estimates for the number of fish per square meter electrofished during autumn 2016 and 2017 in Rock Creek, Washington. 28

Figure 11. Graph showing pool population abundance estimates for the number of fish per square meter electrofished during autumn 2016 and 2017 in Walaluuks Creek, Washington ...

Figure 12. Graphs showing Fulton's condition factor and standard error for age-0 and age 1+ Oncorhynchus mykiss captured by electrofishing in Rock Creek, Washington during autumn 2016 and 2017

Figure 13. Fulton's condition factor and standard error for age- 0 and age $1+$ Oncorhynchus mykiss captured by electrofishing in Walaluuks Creek, Washington, during autumn 2016 and 2017.

Figure 14. Graphs showing Fulton's condition factor and standard error for young of year Coho salmon captured by electrofishing in Rock Creek and Walaluuks Creek, Washington, during autumn 2016 and 2017

Figure 15. Graphs showing Fulton's condition factor and standard error for young of year bridgelip suckers captured by electrofishing in Rock Creek and Walaluuks Creek, Washington, during autumn 2016 and 2017

Figure 16. Graphs showing distribution of first detections of passive-integrated-transponder tagged 0 . mykiss at PIT tag information system detection arrays Rock Creek Squaw and Rock Creek Longhouse by date and Rock Creek discharge at rkm 12.9, 2016-18.

Figure 17. Graphs showing distribution of first detections of passive-integrated-transponder tagged Coho salmon at PIT tag information system detection arrays Rock Creek Squaw and Rock Creek Longhouse by date and Rock Creek discharge at rkm 12.9, Rock or Walaluuks Creek, Washington, 2016-18.

Figure 18. Graph showing steelhead survival estimates with 95 percent confidence intervals for fish tagged with passive integrated transponders and released during 2016 and 2017 in Walaluuks and Rock Creek, Washington and migrating downstream.

Figure 19. Graph showing Coho salmon survival estimates with 95 percent confidence intervals for fish tagged with passive integrated transponders and released during 2016 and 2017 in Walaluuks and Rock Creeks, Washington, and migrating downstream...

\section{Tables}

Table 1. Length of stream that was dry, non-pool wet, or pool, along with the average maximum depth, average mean depth, mean temperature, and maximum temperature of pools in Rock Creek, Washington, during surveys conducted in late August and September of 2015-17.

Table 2. Length of stream that was dry, non-pool wet, or pool, along with the average maximum depth, average mean depth, mean temperature, and maximum temperature of pools in Walaluuks Creek, Washington, during surveys conducted in 2015-17.

Table 3. Summary of Oncorhynchus mykiss and Coho salmon tagged with passive integrated transponder tags in Rock Creek, Washington, and a tributary of Rock Creek, Walaluuks Creek, during autumn 2016 and 2017, and detections at PIT-tag Interrogation Systems in Rock Creek and the Columbia River, Washington.

Table 4. Summary of bridgelip and largescale sucker tagged with passive integrated transponders in Rock Creek, Washington, and a tributary of Rock Creek, Walaluuks Creek, during autumn 2016 and 2017, and detections at PIT-Tag Interrogation Systems in Rock Creek, Washington. 
Table 5. Summary statistics for travel time and travel rate for steelhead first detections between passiveintegrated-transponder tag interrogation arrays Rock Creek Squaw and Rock Creek Longhouse and Rock Creek Longhouse and John Day Dam Juvenile Bypass, Washington.

Table 6. Summary statistics for travel time and travel rate for Coho salmon smolts first detections between passive-integrated-transponder tag interrogation arrays Rock Creek Squaw and Rock Creek Longhouse and Rock Creek Longhouse and John Day Dam Juvenile Bypass, Washington 40

Table 7. Models of survival probability for reach survival analysis of juvenile Oncorhynchus mykiss and Coho salmon released in Walaluuks and Rock Creeks upstream of the confluence with Walaluuks Creek during autumn of 2016 and 2017, Washington.

Table 8. Models of survival probability for reach survival analysis of juvenile Oncorhynchus mykiss and Coho salmon released in Rock Creek between rkm 5 and rkm 13 during autumn of 2016 and 2017, Washington.

Table 9. Survival modeling results by release group, release year, and reach for juvenile Oncorhynchus mykiss released upstream of river kilometer 13 in Rock Creek, in Walaluuks Creek, and in Rock Creek between rkm 5 and 13 for releases made during autumn of 2016 and 2017, Washington.

Table 10. Survival modeling results by release group, release year, and reach for juvenile Coho salmon released upstream of rkm 13 in Rock Creek, in Walaluuks Creek, and in Rock Creek between rkm 5 and 13 for releases made during autumn of 2016 and 2017, Washington. 


\section{Conversion Factors}

U.S. customary units to International System of Units

\begin{tabular}{|c|c|c|}
\hline Multiply & By & To obtain \\
\hline \multicolumn{3}{|c|}{ Length } \\
\hline inch (in.) & 2.54 & centimeter $(\mathrm{cm})$ \\
\hline foot $(\mathrm{ft})$ & 0.3048 & meter $(\mathrm{m})$ \\
\hline mile (mi) & 1.609 & kilometer $(\mathrm{km})$ \\
\hline \multicolumn{3}{|c|}{ Area } \\
\hline square foot $\left(\mathrm{ft}^{2}\right)$ & 0.09290 & square meter $\left(\mathrm{m}^{2}\right)$ \\
\hline square inch $\left(\mathrm{in}^{2}\right)$ & 6.452 & square centimeter $\left(\mathrm{cm}^{2}\right)$ \\
\hline square mile $\left(\mathrm{mi}^{2}\right)$ & 259.0 & hectare (ha) \\
\hline square mile $\left(\mathrm{mi}^{2}\right)$ & 2.590 & square kilometer $\left(\mathrm{km}^{2}\right)$ \\
\hline \multicolumn{3}{|c|}{ Volume } \\
\hline cubic foot $\left(\mathrm{ft}^{3}\right)$ & 0.02832 & cubic meter $\left(\mathrm{m}^{3}\right)$ \\
\hline cubic yard $\left(\mathrm{yd}^{3}\right)$ & 0.7646 & cubic meter $\left(\mathrm{m}^{3}\right)$ \\
\hline cubic mile $\left(\mathrm{mi}^{3}\right)$ & 4.168 & cubic kilometer $\left(\mathrm{km}^{3}\right)$ \\
\hline acre-foot (acre-ft) & 1,233 & cubic meter $\left(\mathrm{m}^{3}\right)$ \\
\hline acre-foot (acre-ft) & 0.001233 & cubic hectometer $\left(\mathrm{hm}^{3}\right)$ \\
\hline \multicolumn{3}{|c|}{ Flow rate } \\
\hline foot per second (ft/s) & 0.3048 & meter per second $(\mathrm{m} / \mathrm{s})$ \\
\hline cubic foot per second $\left(\mathrm{ft}^{3} / \mathrm{s}\right)$ & 0.02832 & cubic meter per second $\left(\mathrm{m}^{3} / \mathrm{s}\right)$ \\
\hline
\end{tabular}

Temperature in degrees Celsius $\left({ }^{\circ} \mathrm{C}\right)$ may be converted to degrees Fahrenheit $\left({ }^{\circ} \mathrm{F}\right)$ as follows:

$$
{ }^{\circ} \mathrm{F}=\left(1.8 \times{ }^{\circ} \mathrm{C}\right)+32 \text {. }
$$

\section{Datums}

Vertical coordinate information is referenced to the, North American Vertical Datum of 1988 (NAVD 88).

Horizontal coordinate information is referenced to the, North American Datum of 1983 (NAD 83).

Altitude, as used in this report, refers to distance above the vertical datum.

\section{Abbreviations}

$\begin{array}{ll}\text { AIC } & \text { Akaike's Information Criteria } \\ \text { CRITFC } & \text { Columbia River Intertribal Fisheries Commission } \\ \text { DPS } & \text { Distinct Population Segment } \\ \text { ESA } & \text { Endangered Species Act } \\ \text { FL } & \text { Fork Length } \\ \text { JDA } & \text { John Day Dam } \\ \text { JDJ } & \text { John Day Dam juvenile bypass } \\ \text { MCR } & \text { Middle Columbia River } \\ \text { MPG } & \text { Major Population Group } \\ \text { MS } & \text { Methanesulfonate } \\ \text { MUX } & \text { Multiplexing Transceiver System (Destron-Fearing 1001M) } \\ \text { NMFS } & \text { National Marine Fisheries Service } \\ \text { NPPC } & \text { North Power Planning Council } \\ \text { NWFSC } & \text { Northwest Fisheries Science Center } \\ \text { PIT } & \text { Passive Integrated Tag } \\ \text { PTAGIS } & \text { Columbia Basin PIT Tag Information System } \\ \text { PTIS } & \text { PIT Tag Interrogation System } \\ \text { RCL } & \text { Rock Creek Longhouse } \\ \text { RCS } & \text { Rock Creek Squaw } \\ \text { Rkm } & \text { River kilometer } \\ \text { SE } & \text { Standard Error } \\ \text { USGS } & \text { U.S. Geological Survey } \\ \text { YN } & \text { Yakama Nation } \\ & \end{array}$




\title{
Fish and Habitat Assessment in Rock Creek, Klickitat County, Washington, 2016-17
}

\author{
By Jill M. Hardiman ${ }^{1}$ and Elaine Harvey²
}

\section{Executive Summary}

Intermittent streams are important and productive for salmonid habitat. Rock Creek, in southeastern Washington, flows south to the Columbia River at river kilometer (rkm) 368 and is an intermittent stream of great significance to the Yakama Nation and to the Kah-miltpah (Rock Creek) Band in particular. Historically, native steelhead (anadromous form of rainbow trout [Oncorhynchus mykiss]) and bridgelip sucker (Catostomus columbianus) populations were used by the Kah-miltpah Band for sustenance, trade, and traditional practices. Anadromous salmonid populations currently present and being monitored in the Rock Creek subbasin include Coho (O. kisutch) salmon and steelhead. Resident rainbow trout are also present and monitored (rainbow trout and steelhead will be collectively referred to as $O$. mykiss throughout this report). Streamflow is a limiting habitat factor in this system, but despite this, steelhead and Coho salmon still successfully return to spawn, rear, out-migrate, and survive over-summer in many of the isolated pools.

We completed habitat surveys during 2015-17 to assess the perennial pools during lowflow conditions. The lower river sections ( $\mathrm{rkm} 2-13$ ) had proportionately more dry sections than the upper river sections (rkm 14-22) for all years surveyed and had higher variability among habitat types across years. The surveyed dry sections within the lower river ranged from 44 to 57 percent, with 2015 (a drought year) as the highest and 2017 the lowest. The percentage of pool habitat in the lower river was 21-24 percent, with 2015 as the lowest and 2016 and 2017 both at 24 percent. The upper river sections had a relatively high percentage of non-pool wet habitat (49-51 percent), followed by dry (33-36 percent) and pool habitat (17-18 percent). In Walaluuks Creek, the percentage of pool habitat was the most consistent across the years, ranging from 10 to 13 percent.

Fish species distribution, relative abundance, length-frequency, and salmonid pool density were determined by backpack electrofishing in stratified, systematically selected pools. During 2016, 675 O. mykiss were handled, with 454 passive-integrated-transponder (PIT) tagged, and 849 Coho salmon were handled with 459 PIT tagged. During 2017, 1,107 O. mykiss were handled, with 699 PIT tagged, and 495 Coho salmon handled with 420 PIT tagged. For 
bridgelip suckers during 2016, we handled 235 with 65 PIT tagged. During 2017, we handled 947 with 224 PIT tagged within Rock Creek and handled 50 with 19 PIT tagged in Walaluuks Creek. Rock Creek pool abundance $(\mathrm{n}=11)$ for age-0 O. mykiss during 2016 had an average density of 0.236 (range: $0.007-0.692$ ) fish per square meter $\left(\mathrm{m}^{2}\right)$ and for 2017 an average density of 0.208 (range: $0.003-0.341 ; \mathrm{n}=6)$ fish per $\mathrm{m}^{2}$. The average pool density $(\mathrm{n}=5)$ of age- $O$. mykiss for 2016 was 0.014 (range: $0.002-0.038$ ) fish per $\mathrm{m}^{2}$, which was lower than the average pool density $(\mathrm{n}=5)$ for 2017 of 0.048 (range: $0.004-0.120$ ) fish per $\mathrm{m}^{2}$. During 2016, Coho salmon pool abundance estimates in Rock Creek averaged 0.821 (range: 0.017-3.639; $\mathrm{n}=6$ ) fish per $\mathrm{m}^{2}$ and during 2017 averaged 0.237 (range: $0.001-0.661 ; \mathrm{n}=6$ ) fish per $\mathrm{m}^{2}$. During 2016, Coho salmon pool abundance estimates in Walaluuks Creek averaged 1.793 (range: 0.185-3.679; $\mathrm{n}=5$ ) fish per $\mathrm{m}^{2}$, and during 2017 averaged 0.421 (range: $0.185-0.797 ; \mathrm{n}=4$ ) fish per $\mathrm{m}^{2}$. Salmonid pool abundance in Rock Creek subbasin varies by pool, year, and species; however, estimates were much lower in 2016-17 than in 2011-12.

There was high variability in bridgelip sucker pool abundance estimates across years. During 2016, the mean pool abundance estimate was 0.171 (range: $0.003-0.757 ; n=6$ ) fish per $\mathrm{m}^{2}$, which was lower than the 2017 abundance of 1.197 (range: $0.059-3.378 ; \mathrm{n}=6$ ) fish per $\mathrm{m}^{2}$ in Rock Creek. The mean pool abundance in Waluluuks Creek was 0.045 (range: 0.003-0.109; $\mathrm{n}=4$ ) fish per $\mathrm{m}^{2}$ during 2017. Apparent survival of PIT-tagged bridgelip suckers detected in Rock Creek was 20 percent in 2016 and 25 percent in 2017.

During 2016 and 2017, salmonid survival estimates were modeled by release group, year, and reach. Overwinter survival results for O. mykiss (range: 36-55 percent) were higher than past results from 2009-12 for all release groups, except for $O$. mykiss released downstream of Walaluuks confluence (Rock Creek Squaw [RCS] PIT Tag Information System [PTIS]) during 2016 (21 percent). Reach survival for the Rock Creek Longhouse (RCL) PTIS ranged from 67 to 100 percent for release groups by year. For John Day Dam (JDA), reach survival ranged from 54 to 90 percent for $O$. mykiss released upstream of RCS and 41 to 76 percent for fish released downstream of RCS during 2016-17. Generally, apparent overwinter survival estimates for Coho salmon released upstream of RCS were higher (35-66 percent) than those of $O$. mykiss. During 2016, both $O$. mykiss and Coho salmon released downstream of RCS had relatively low apparent overwinter survival (21 percent) compared to 55 percent for $O$. mykiss and 40 percent for Coho salmon during 2017. Reach survival for RCL was generally higher for Coho salmon (90-97 percent) than for $O$. mykiss when released upstream of RCS. For JDA, reach survival ranged from 63 to 86 percent for Coho salmon released upstream of RCS and 53 to 100 percent for Coho salmon released downstream of RCS.

Even though Rock Creek has intermittent flow throughout the year, there remains persistent suitable habitat in reaches throughout the subbasin. Pacific salmonids show a high degree of plasticity in adapting to changing environmental conditions and intermittent streams are proving to be important for salmon productivity. Protection of current suitable habitat should be a priority; however, protection alone is not likely to be sufficient to conserve salmonid populations. Restoring streamflow regimes, increasing connectivity, reducing water withdrawals, and restoring floodplain and riparian function may be able to ameliorate temperature increases and base-flow decreases. Instream rehabilitation such as addition of structure may also ameliorate temperature increases and may provide additional cover and refuge for fish. Ongoing monitoring of the Endangered Species Act-listed O. mykiss will inform progress towards National Marine Fisheries Service Rock Creek population recovery goals and contribute to the larger recovery goals for the Mid-Columbia River Distinct Population Segment. 


\section{Introduction}

Intermittent streams, which go dry during low-flow periods but have persistent isolated pools are abundant and have recently emerged as a new field of research to better understand impacts on stream communities and food webs (Bogan and others, 2013; Datry and others, 2014; Hwan and Carlson 2016; Woelfle-Erskine and others, 2017; Hwan and others, 2018). Furthermore, they are proving to be important and productive for salmonid habitat (Wigington and others, 2006; Ebersole and others, 2009; Woelfle-Erskine and others, 2017; Hwan and others, 2018). Climate change has negative implications for salmonid habitat in the Pacific Northwest (Mantua and others, 2010; Wade and others, 2013; Mote and others, 2014; Raymond and others, 2014; May and others, 2018). Increasing numbers of intermittent streams, increased duration of intermittency, warming stream temperatures, and droughts have all occurred in regions of critical salmonid habitat (Mantua and others, 2010; Sloat and Osterback, 2012; Hwan and others, 2018; Woelfle-Erskine and others, 2017; Obedzinkski and others, 2018). Climate plays a role in every stage of the life cycle of Pacific salmon (Crozier and others, 2008; Beechie and others, 2013; Wade and others, 2013), but the relative importance can vary among different populations (Mantua and others, 2010; Wade and others, 2013). Key limiting factors to productivity include thermal and hydrologic regimes that are influenced by watershed characteristics, life histories, and stock-specific adaptations to local environmental factors (Crozier and others, 2008; Mantua and others, 2010; Wade and others, 2013). It is generally believed that predicted climate change effects will vary widely throughout the Pacific salmon range and that species life-history diversity will influence the likelihood of their persistence throughout most of their range, despite potential climatic shifts in temperature and flows (Waples and others, 2009; Mantua and others, 2010). Local adaptation, life-history diversity, spatial diversity, and plasticity of salmonids influence resiliency to climate effects and population persistence (Crozier and others, 2008; Crozier and Hutchings 2014; Hwan and others, 2018). Understanding which populations persist, how they persist, and what can be done to maintain and increase resiliency under harsh conditions will inform resource manager decisions on recovery strategies and critical habitat.

Rock Creek, located in southeastern Washington (fig. 1), flows south to the Columbia River at river kilometer (rkm) 368 and is an intermittent stream of great significance to the Yakama Nation and to the Kah-miltpah (Rock Creek) Band in particular. Historically, the native steelhead (anadromous form of rainbow trout [Oncorhynchus mykiss]) and bridgelip sucker (Catostomus columbianus) populations were used by the Kah-miltpah Band for sustenance, trade, (Northwest Power Planning Council, 2004) and for traditional practices. Low-flow habitat surveys during late summer have consistently shown an intermittent streamflow pattern with disconnected perennial pools (Harvey, 2014; Harvey, 2015). Large sections of Rock Creek dry completely during summer, and flow connectivity does not return until late autumn and early winter. During 2015, which was a drought year, 46 percent of the stream length (from rkm 2-22) surveyed was dry and 20 percent was pools (Harvey, 2015). High water temperatures over summer and early autumn further challenge survival of juvenile salmonids in lower Rock Creek sections (Harvey, 2015). Rock Creek lacks instream complexity, shallow bedrock and boulder sub-armor contribute to infrequent and shallow pool structures that lack cover and large woody debris is generally absent from the low-flow channel and is not a habitat forming agent (Conley, 2015).

Anadromous salmonid populations currently present and being monitored in the Rock Creek subbasin include Coho salmon (O. kisutch), steelhead and resident rainbow trout 
(collectively referred to as $O$. mykiss). Streamflow is a limiting habitat factor in this system, but despite this, O. mykiss and Coho salmon still successfully return to spawn, rear, out-migrate, and survive over summer in many of the isolated pools (Harvey, 2014; Harvey, 2015). Smolt-to-adult return rates for the 3,039 steelhead smolts tagged in the Rock Creek subbasin during 2009-12 ranged from 2.2 to 5.5 percent (Harvey, 2015). During this time, Coho salmon were only abundant in larger numbers in Rock Creek subbasin in 2011, in which 151 were tagged and, of these, 2 returned to Rock Creek.

The native steelhead population within Rock Creek is considered an independent population of the Middle Columbia River (MCR) steelhead distinct population segment (DPS), which was listed as threatened under the Endangered Species Act (ESA) on January 5, 2006 (National Oceanic and Atmospheric Administration; National Marine Fisheries Service, 2009a and 2009b). The Rock Creek population is within the Cascade Eastern Slopes Tributaries major population group (MPG). The National Marine Fisheries Service 2016 5-year Review of the Middle Columbia River Steelhead identifies a recovery goal for the Rock Creek population to reach a maintained population status defined as 25 percent or less risk level (Northwest Fisheries Science Center, 2015; National Marine Fisheries Service, 2016). Ongoing monitoring work of this population will inform progress towards this recovery goal and contribution to the larger recovery goals for the MCR DPS.

Bridgelip suckers are a culturally significant species of concern to the Yakama Nation and the Kah-miltpah Band. The bridgelip sucker was historically abundant throughout the Rock Creek subbasin. In the last decade, it has been observed by the Tribal members that suckers are less abundant for ceremonial and subsistence harvest. Very little information is currently known about the movement, distribution and abundance of bridgelip sucker in Rock Creek. In previous years, the presence of bridgelip suckers was documented during juvenile salmonid abundance and population surveys (Harvey, 2014). In 2016, monitoring began for bridgelip sucker distribution, abundance, and movement using mark-recapture techniques for pool population abundance estimates and monitoring for movement.

The U.S. Geological Survey (USGS) and the Yakama Nation (YN) have collaborated in the Rock Creek subbasin since 2009 to assess $O$. mykiss populations and habitat conditions. The Yakama Nation Fisheries Resource Management Program is using a three-pronged approach to restore watershed health and aid recovery of salmonids and culturally significant fish species in Rock Creek subbasin. First, assessment of the current fish use, water quality/quantity, and habitat conditions to determine areas of high salmonid productivity and survival, and the primary limiting habitat factors. Second, creation of a list of prioritized actions to protect, restore, and enhance stream reaches. Third, conduct restoration actions to address restoration priorities, and monitor the effectiveness of restoration activities. The overall goal of this project is to improve habitat conditions of salmonids listed under the ESA and culturally significant fish species in the Rock Creek subbasin towards supporting sustainable populations.

This assessment focuses on the juvenile fish monitoring and habitat work completed during 2016-17. Results from the 2016-17 fish tagging efforts allow for comparisons to past work (2009-12) and a better understanding of baseline conditions for assessing distribution, abundance, productivity, and survival of salmonids within the Rock Creek subbasin (Harvey, 2014; Harvey, 2015). Continued efforts include monitoring the abundance, distribution, and survival of smolts, assessing the number of out-of-basin spawners, and refining the smolt-toadult return rates for within basin salmonids. Continued monitoring of salmonids within this basin will address these as well as population status information towards reaching ESA recovery 
goals. It is also contributing to restoration planning within the subbasin by identifying reaches where salmonids are successfully surviving and rearing through consistent distribution and abundance numbers and will provide a basis for effectiveness monitoring of future restoration projects. It will also further our understanding of the importance of intermittent streams and local species adaptation and persistence in the face of challenging environmental conditions. 


\section{Study Area}

Rock Creek, a Washington State tributary that flows south to the Columbia River at river kilometer (rkm) 368, is located 21 kilometers (km) upstream of John Day Dam (JDA; Harvey, 2014). The watershed encompasses an area of 578 square kilometers $\left(\mathrm{km}^{2} ;\right.$ fig. 1). Lake Umatilla, the reservoir behind JDA, inundates the lower $2 \mathrm{~km}$ of Rock Creek and is at 81 meters (m) altitude. The headwaters of Rock Creek originate in the Simcoe Mountains, which are the watershed's northern border at an altitude of $1,433 \mathrm{~m}$, on the southern border of the Yakama Nation Reservation. The average annual precipitation in Rock Creek varies from about 24 centimeters $(\mathrm{cm})$ at the mouth to $65 \mathrm{~cm}$ near the headwaters (Conley, 2015). Major tributaries to Rock Creek include Walaluuks Creek (formerly named Squaw Creek) at rkm 13, Luna Gulch at rkm 18.5, and Quartz Creek at rkm 27. From June through October, the streamflow in Rock Creek and its tributaries decreases, becoming intermittent until the autumn rains resume (generally in October or November). The fish habitat in Rock Creek is spatially diverse ("patchy") and variably suitable during the low-flow period, particularly in the more downstream reaches. Therefore, the most limiting habitat factor is instream flows during the low-flow period, reducing connectivity and creating isolated pools which can have direct and indirect impacts on survival through predation, thermal stress, disease/parasite infestation, and competition for limited resources.

The Rock Creek subbasin is of great significance to the Yakama Nation and to the Kahmiltpah Band in particular. The Kah-miltpah Band lived in the subbasin for thousands of years and survived on the historically abundant source of fish, wildlife, and plants in the subbasin. Salmon, steelhead, Pacific lamprey (Entosphenus tridentatus), and bridgelip suckers are all culturally significant species that were once abundant prior to the JDA inundation to the lowest 2 $\mathrm{km}$ of the mainstem Rock Creek. There is a Yakama Nation longhouse at rkm 6, and the primary land ownership within the study area is either Yakama Nation or private.

\section{Methods}

\section{Stream Pool Habitat Surveys}

We completed habitat surveys of the Rock Creek subbasin in 2016 and 2017 to assess the perennial pools during low-flow conditions. The surveys started where Rock Creek and the backwater caused by JDA converge (rkm 2). During the survey, we measured the lengths of all dry and non-pool wet sections and for pools: the length, wetted width, average residual depth, maximum residual depth, and temperature. Lengths were recorded using a range finder and measuring tape for sections that were highly vegetated. Data were recorded using an iPad with GIS Pro software for a digital version in addition to hard paper format for subsequent data proofing. A photo was taken at each habitat unit.

A flow gage was maintained and monitored at the Highway 8 bridge (rkm 12.9) by $\mathrm{YN}$ and USGS personnel. The flow gage recorded stage height and water temperature every 15 minutes during periods of continuous streamflow. Air temperature, stream temperature, and water quality were monitored at several key locations on a seasonal basis to characterize the conditions of the subbasin by YN (Elaine Harvey, Yakama Nation Fisheries written commun., 2017). 


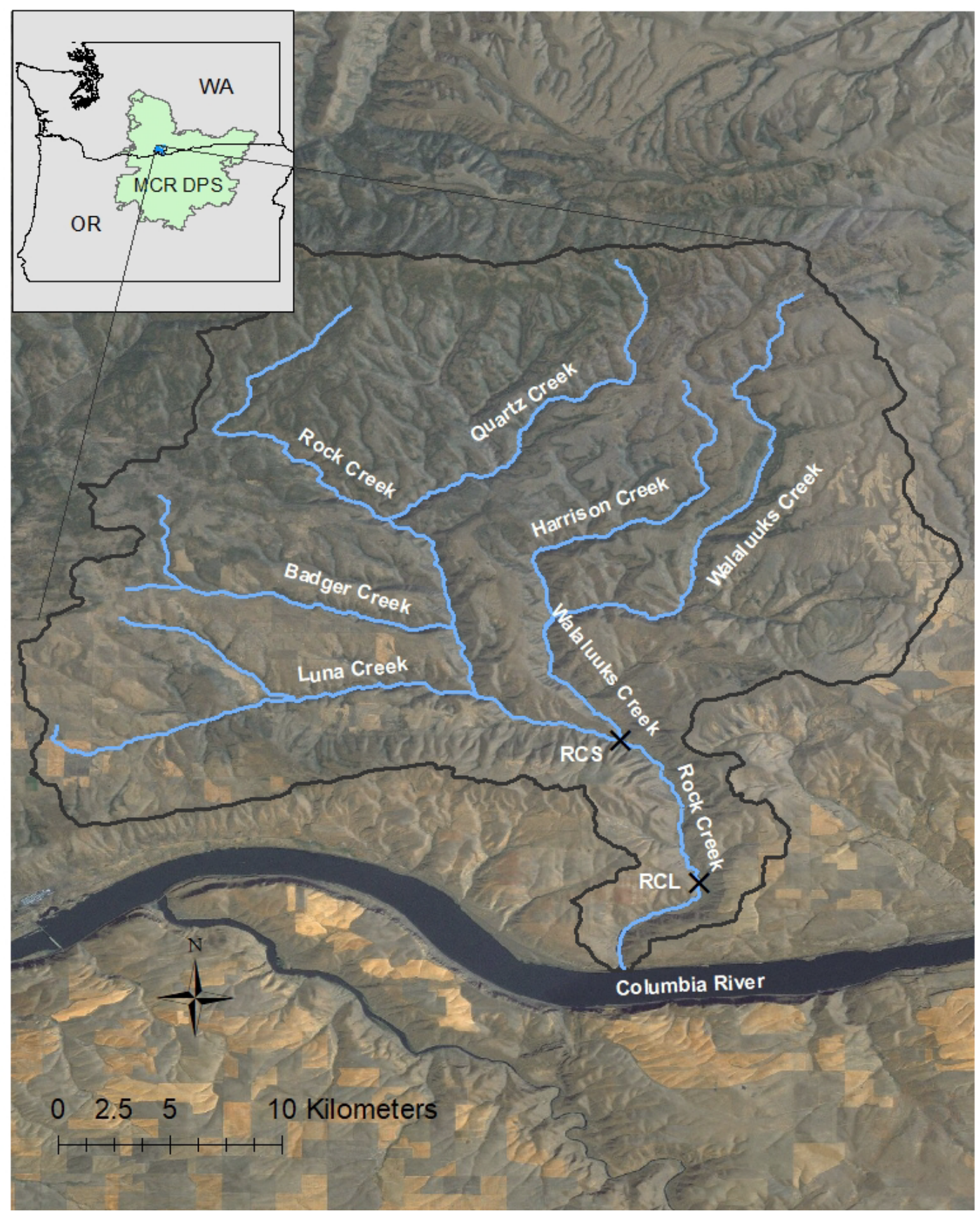

Figure 1. Map showing the Rock Creek subbasin (indicated by black outline) and locations of tributary streams and passive-integrated-transponder-tag interrogation systems (X) Rock Creek Squaw (RCS, river kilometer [rkm] 13) and Rock Creek Longhouse (RCL, rkm 5) in Rock Creek, Washington. [Smaller map inset shows the location of the subbasin within the Middle Columbia River Steelhead Distinct Population Segment (MCR DPS).] 


\section{Fish Sampling and Tagging}

Fish species distribution, relative abundance, length-frequency, weights, and salmonid pool density were determined by backpack electrofishing perennial pools with maximum depth greater than or equal to $60 \mathrm{~cm}$. In autumn, habitat surveys were conducted prior to electrofishing to measure the length, width, and depth of pools and non-pool wet reaches in all anadromous fish-bearing reaches where we had landowner permission and access. Sampling was limited to pools (maximum depth greater or equal to $60 \mathrm{~cm}$ ) for pool abundance estimates. However, additional fish sampling did occur in riffles and glides upstream and downstream of population abundance pools to increase the numbers of fish PIT tagged for survival, travel time, and future smolt to adult return analyses. In addition to using a stratified, systematic sample design with a randomly selected starting pool to determine which pools to sample within a study year, some legacy pools (perennial both years) were sampled consistently across years where possible for comparison to past results (2009-12). Some pools were not suitable for efficiently and adequately sampling via backpack electrofishing and the available crew where maximum depths were greater than $120 \mathrm{~cm}$ and the average depth was greater than $100 \mathrm{~cm}$, or a large portion of the pool area was not accessible by equipment or personnel. Alternate pools were chosen as needed by selecting the nearest pool that was suitable for sampling until at least eight pools were sampled with four pools occurring in each the lower (rkm 2-13) and upper (rkm 14-22) sections of Rock Creek. A similar process was used for sampling in Walaluuks Creek, identifying pools to sample that had a maximum depth greater or equal to $60 \mathrm{~cm}$, from the confluence with Rock Creek up to about rkm 8.5. For Walaluuks Creek, four pools were selected and two legacy pools were also included.

Pools were electrofished using a battery-powered Smith-Root model 12-B backpack electrofisher (Smith Root Inc., Vancouver, Washington). The electrofisher settings of voltage, frequency, and duty cycle were determined by the physical characteristics of the site (water conductivity, creek size, water volume, etc.). The lowest effective electrofisher settings were used in order to minimize fish injury. The electrofisher settings were typically $60 \mathrm{hz}, 6$ milliseconds, and $300 \mathrm{~V}$. Two to three crew members with dip nets remained downstream from the electrofisher and netted stunned fish. Fish sampling consisted of single-pass electrofishing upstream from the pool tail-out to the pool head and back downstream to the tail-out within each pool. We attempted to capture all juvenile salmonids, sucker spp. (primarily bridgelip), and a subset of any other fish species observed while electrofishing to determine fish species composition in each pool. All captured fish were immediately placed into plastic buckets filled with ambient stream water and fitted with aerators. Captured fish were anesthetized with the lowest possible dose of tricaine methanesulfonate (MS-222) before handling (about $50 \mathrm{mg} / \mathrm{L}$ MS-222). Because the effectiveness of MS-222 as an anesthetic varies with factors such as temperature and fish density, the concentration of anesthetic was adjusted. Adjustment of the anesthetic concentration was based on the amount of time it takes for a group of fish to lose equilibrium. The goal was for the induction time to be between 1 and 5 minutes. After handling, the fish were placed in a 5-gallon bucket fitted with aerators and filled with ambient stream water where they were held until they fully regained equilibrium. After the fish recovered, they were released back to the pool from where they were captured. The exception to this protocol was when a fish died before or during handling.

After anesthetizing, all captured fish were identified to the species level, scanned for PIT tags, measured for fork length (FL) to the nearest millimeter ( $\mathrm{mm})$, weighed to the nearest $0.1 \mathrm{~g}$ and inspected for external signs of disease or parasite infection. Tissue samples (fin clip) from a 
subsample of salmonids were preserved for genetic analyses. Genetic samples were submitted to the Columbia River Inter-Tribal Fish Commission (CRITFC) for analysis. In order to individually mark fish to track movements, estimate abundance, and measure growth, we inserted PIT tags (12 mm; 134.2 kilohertz [kHz]) in the peritoneal cavity of salmonids and a subset of bridgelip suckers that exceeded 70-mm FL. All PIT tagging followed the procedures outlined by Columbia Basin Fish and Wildlife Authority (1999). All PIT-tag data were entered in the Columbia Basin PIT Tag Information System (PTAGIS) database, maintained by Pacific States Marine Fisheries Commission (2009). To mark fish less than 70-mm FL, a fin clip was used on the caudal fin. During the recapture pass the following day, unmarked salmonids exceeding 70-mm FL were PIT tagged, but unmarked salmonids less than $70 \mathrm{~mm}$ were returned to the stream unmarked.

\section{Pool Population Estimates and Condition Factor}

We estimated population density and biomass of salmonids by using the mark-recapture method as detailed in Temple and Pearsons (2007). We anchored block nets, with each spanning the creek, at the upstream and downstream end of each pool. The nets were constructed of 3-mm knotless nylon mesh. The weighted line of each net was secured to the stream bottom with cobble and boulders. Sticks or other material were used to prop up each net at least $0.5 \mathrm{~m}$ above the water surface. This was done to ensure no fish immigration or emigration (that is, closed population) during the estimate. Each pool was electrofished via an upstream and downstream pass and all captured salmonids were marked (that is, PIT tag, fin clip), returned to the sampled pool, the block nets were cleaned and left overnight, and the pool was re-electrofished to recapture fish the following day. This allowed for a minimum recovery period of 18 hours.

For our mark-recapture data analysis, we used length-frequency histograms to assign ages to age- 0 and age- 1 or older fish (appendix 1) and then estimated the abundance of age- 0 (less than $110 \mathrm{~mm} \mathrm{FL}$ ) and age-1 or older (greater than or equal to $110 \mathrm{~mm}$ FL) salmonids as follows:

$$
\mathrm{N}=[(\mathrm{M}+1) *(\mathrm{C}+1) / \mathrm{R}+1]-1
$$

where,

$\mathrm{M}$ is number of fish marked on the first sample,

$\mathrm{C}$ is number of fish captured in the second sample, and

$\mathrm{R}$ is number of marked fish captured in the second sample (Chapman, 1951).

Population abundance estimates were converted to densities (fish per $\mathrm{m}^{2}$ ) for each pool for a standardized comparison across pools since pool size was highly variable. Additional pool measurements were taken at the time of sampling for population abundance in order to estimate the surface sample area. Measurements included the pool length and wetted width measurements at the pool tail out and head of the pool, as well as at one quarter, half, and three-quarter lengths of the pool. Sample area was then calculated using the pool length multiplied by the average wetted width for the three middle measurements.

Conducting pool population abundance estimates provides an index over time to detect potential trends in pool abundance and species diversity for salmonids within the Rock Creek subbasin. This also provides current status data and improved understanding of the variability of species abundance and diversity within pools throughout the study area. Due to high variability in pool abundance and limitations on sampling efforts based on time and budget constraints, the expansion of population estimates throughout the study area has not been done. 
Fulton's condition factor $(\mathrm{K})$ was also calculated for fish sampled within pools and habitat reaches as follows:

$$
\mathrm{K}=\mathrm{W} /(\mathrm{FL})^{3} * 100,000(2)
$$

where,

$\mathrm{W}$ is the weight of fish in grams, and

FL is the fork length of the fish in millimeters.

\section{Passive-Integrated-Transponder-Tag Interrogation}

Two multiplexing PIT-tag interrogation systems (PTISs) were installed in Rock Creek in autumn 2009 to evaluate timing and degree of salmonid movement, survival, adult stray rate, and other life history attributes. These PTISs were built and installed by USGS and maintained and downloaded by the YN. One PTIS was installed near the Rock Creek Longhouse at rkm 5 (RCL) and powered by grid power, with three arrays in an upstream to downstream orientation where each consisted of two side-by-side antennas. The other PTIS was installed at the confluence with Walaluuks Creek at rkm 13 (RCS) and was powered by a solar panel array (fig. 1). The RCS PTIS was installed with one array composed of two antennas at $40 \mathrm{~m}$ upstream of Walaluuks Creek. A single array of two antennas was installed at $20 \mathrm{~m}$ downstream of Walaluuks Creek and two arrays with single antennas in Walaluuks Creek about $3 \mathrm{~m}$ apart and $5 \mathrm{~m}$ upstream of the confluence. All antennas at both sites were $6.1-\mathrm{m}$ long and 1 -m wide and were anchored in passby orientation (flat to the substrate). The PTIS transceivers were Destron-Fearing $1001 \mathrm{M}$ Multiplexing Transceiver System (MUX) that can power up to six $6.1 \mathrm{~m}$ long antennas. These transceivers were designed to detect $134.2 \mathrm{kHz}$ full-duplex tags, the standard PIT tag used in salmonids in the Columbia River basin. To reduce electrical interference within the PITSs, grid power or solar panels were connected to a charging circuit that contained two banks of batteries (each bank consisted of two $12 \mathrm{~V}$ batteries wired in series for $24 \mathrm{~V}$ ) and a switching mechanism to alternately charge one bank of batteries while the other bank was isolated from the charging circuit and powering the MUX. To protect the MUXs from the high summer air temperatures, they were removed from July through October when the pools were disconnected, thus eliminating the opportunity for fish movement.

\section{Survival Estimates and Travel Times}

Survival estimates were calculated for fish that were PIT tagged in Walaluuks Creek, Rock Creek above the confluence with Walaluuks Creek, and Rock Creek downstream of the confluence with Walaluuks Creek but upstream of the RCL PTIS during 2016 and 2017. These estimates were based on PTIS detections over time using Cormack-Jolly-Seber estimates (Cooch and White, 2010) and the RMARK package within program R (2008). In the context of survival estimates, the passive detection of PIT-tagged smolts at any other PTIS downstream of tagging location was considered a "recapture." Recapture data on fish tagged in Rock Creek were downloaded using the PTAGIS database maintained by Pacific States Marine Fisheries Commission. Data from the PTAGIS database was then used to create individual capture histories for fish detections. A suite of survival models were compared using AICc analysis and ranked based on Delta AICc (Burnham and Anderson, 2002). Cormack-Jolly-Seber survival estimates were a combination of both survival and fish emigration. The estimate at the first potential site for detection (usually the first site downstream of where the fish was tagged; RCS 
for fish tagged upstream of rkm 13 or in Walaluuks Creek and RCL for fish tagged in Rock Creek from rkm 5 to 13) was considered to be the apparent survival. The apparent survival estimate counts fish mortalities that died prior to emigrating as well as fish that exhibit a resident life history and do not migrate to the first potential site for detection. Additionally, the survival estimate at the first downstream detection site includes over-winter survival, since fish were tagged during autumn months and typically did not migrate downstream until the following spring. We assumed that any fish that began to migrate and was detected at RCS (RCL for fish tagged and released downstream of RCS) continued through all potential detection sites down to the Columbia River estuary. Any fish that stop to rear and cease migration (potadromous $O$. mykiss, for example) would be evaluated as mortalities for these survival estimates.

A suite of survival models was developed to determine if there were differences in survival between reaches, groups of fish released in Walaluuks Creek, Rock Creek upstream of RCS, and Rock Creek downstream of RCS but upstream of RCL (release group), and between release years. Detection probability models were also evaluated for differences between reaches and release year. For both $O$. mykiss and Coho salmon released upstream of RCS, five candidate survival models were evaluated: (1) reach; (2) an additive model with reach and release group; (3) an additive model with reach and release year; (4) an additive model with reach, release group, and release year; and (5) an interaction model between reach, release group, and release year. Three detection probability models were evaluated: (1) reach; (2) an additive model with reach and release year; and (3) an interaction model of reach and release year. For O. mykiss and Coho salmon released upstream of RCL but downstream of RCS, three survival models were evaluated: (1) reach; (2) an additive model with reach and release year; and (3) an interaction model with reach and release year. The same detection probability models evaluated for upstream releases were also used for fish released between RCS and RCL. Survival models were evaluated first to determine the best-fit model using AICc analysis and ranked based on Delta AICc (Burnham and Anderson, 2002). Using the best-fit model, the detection probabilities were then evaluated to see if it would improve the fit of the model. If a different detection probability was found to improve the model fit, then this was used to reevaluate the survival probability models for best fit. For bridgelip suckers, apparent survival was evaluated for fish released in 2016 and 2017, which included fish being detected at either RCS or RCL at any time after release.

Individual capture histories were also used to calculate migration travel times between RCS and RCL, and RCL, and JDA for O. mykiss and Coho salmon. Travel times were calculated as the time difference between first detections at RCS and RCL, and first detection time differences between RCL and JDA.

\section{Results}

\section{Stream Pool Habitat Surveys}

Surveys were conducted from September 8 through 21, 2016, and from August 24 through September 15, 2017, and covered about 26 and 20 rkm in Rock Creek (table 1). Walaluuks Creek was also surveyed from its confluence with Rock Creek to about rkm 9 in 2016 and rkm 8 in 2017 (table 2). Surveys were a continuation of work done in 2015 (Harvey, 2017) and will be presented in this context. During 2015 and 2016, stream surveys extended to rkm 28 and during 2017 surveys extended to rkm 22 (fig. 2). The shorter survey length in 2017 was designed to match private property access where fish sampling was also allowed. During 2017 , 
of the stream length surveyed, 43 percent was dry (table 1). This was higher than the percentages of dry stream length for the surveys completed in 2015 and 2016 that extended upstream to about $\mathrm{rkm} 28$, indicating proportionately more non-pool wet habitat upstream of rkm 22 (fig. 2). The lower river sections ( $\mathrm{rkm} 2-13$ ) had proportionately more dry sections than the upper river sections (rkm 14-22) for all years surveyed and higher variability among habitat types across years (table 1). The surveyed dry sections within the lower river ranged from 44 to 57 percent, with 2015 (a drought year) as the highest and 2017 the lowest. The non-pool wet habitat is the most variable habitat classification, which can include wetted areas that may or may not be suitable as fish habitat. The percentage of non-pool wet lengths in the lower river were 22-32 percent, with 2015 as the lowest and 2017 the highest. The percentage of pool habitat in the lower river was 21-24 percent, with 2015 as the lowest and 2016 and 2017 both at 24 percent. The upper river section had a relatively high percentage of non-pool wet habitat (49-51 percent), followed by dry habitat (33-36 percent) and pool habitat (13-17 percent; table 1).

Surveys for Walaluuks Creek were also completed from 2015 to 2017 (table 2). The percentage of pool habitat was the most consistent across the years, ranging from 10 to 13 percent. The percentage of dry and non-pool wet habitats were more variable across years. Some of the variability may be associated with changes in the thalweg as well as the difficulty in measuring channel bed length consistently across long sections (which are common between rkm 4 and 7). The percentage of dry habitats ranged from 45 to 62 percent and non-pool wet habitats from 25 to 42 percent (table 2). The highest percentage of dry habitat and the lowest percentage of non-pool wet habitat was observed in 2015, which was a drought year.

Maps were created from the survey data using GPS point locations to create habitat reach classifications for comparison across years (fig. 2). Generally, habitat types are consistently occurring in similar locations across years; however, the length of reach may vary, and the exact rkm measurement may vary. The most habitat variability appears to be in the lower section of Rock Creek. During the 2016 survey, some channel variations occurred creating multiple channels (near rkm 5 and 6) to survey which were not surveyed in 2015 or 2017. Variation occurs due to physical changes within the Rock Creek subbasin but some is also likely associated with variation in sampling among staff across years. 
Table 1. Length of stream that was dry, non-pool wet, or pool, along with the average maximum depth, average mean depth, mean temperature, and maximum temperature of pools in Rock Creek, Washington, during surveys conducted in late August and September of 2015-17.

[Surveys were not conducted upstream of rkm 22 in 2017. Abbreviations: $\mathrm{cm}$, centimeter; m meter; $\mathrm{m}^{2}$, square meter; Rkm, river kilometer; ${ }^{\circ} \mathrm{C}$, degrees Celsius]

\begin{tabular}{|c|c|c|c|c|c|c|c|c|c|}
\hline & \multicolumn{3}{|c|}{ Rkm 2-13 } & \multicolumn{3}{|c|}{ Rkm 14-22 } & \multicolumn{2}{|c|}{ Rkm 2-28 } & \multirow{2}{*}{$\begin{array}{c}\text { Rkm 2-22 } \\
2017\end{array}$} \\
\hline & 2015 & 2016 & 2017 & 2015 & 2016 & 2017 & 2015 & 2016 & \\
\hline $\begin{array}{l}\text { Total stream length } \\
\text { surveyed }(\mathrm{m})\end{array}$ & 12,030 & 12,377 & 11,567 & 8,822 & 8,991 & 7,758 & 27,324 & 28,190 & 20,062 \\
\hline Length dry (m) & 6,786 & 6,350 & 5,110 & 2,860 & 3,046 & 2,813 & 10,549 & 10,817 & 8,660 \\
\hline Percent dry & 57 & 51 & 44 & 33 & 34 & 36 & 38 & 38 & 43 \\
\hline $\begin{array}{l}\text { Length non-pool that } \\
\text { was wet (m) }\end{array}$ & 2,691 & 3,089 & 3,705 & 4,432 & 4,453 & 3,911 & 11,674 & 12,191 & 7,616 \\
\hline Percent non-pool wet & 22 & 25 & 32 & 50 & 49 & 51 & 43 & 43 & 38 \\
\hline Number of pools & 62 & 83 & 70 & 60 & 70 & 46 & 172 & 206 & 116 \\
\hline Total length of pools (m) & 2,553 & 2,938 & 2,752 & 1,530 & 1,492 & 1,034 & 5,101 & 5,182 & 3,786 \\
\hline Percent pool & 21 & 24 & 24 & 17 & 17 & 13 & 19 & 19 & 19 \\
\hline Mean pool length (m) & 41 & 35 & 39 & 26 & 21 & 23 & 30 & 25 & 33 \\
\hline Mean pool area $\left(\mathrm{m}^{2}\right)$ & 381 & 311 & 340 & 153 & 113 & 123 & 224 & 182 & 254 \\
\hline $\begin{array}{l}\text { Mean max depth of } \\
\text { pools }(\mathrm{cm})\end{array}$ & 68 & 65 & 72 & 55 & 51 & 58 & 58 & 54 & 66 \\
\hline $\begin{array}{l}\text { Average mean depth of } \\
\text { pools }(\mathrm{cm})\end{array}$ & 36 & 35 & 32 & 25 & 27 & 28 & 29 & 29 & 31 \\
\hline $\begin{array}{l}\text { Mean temperature of } \\
\text { pools }\left({ }^{\circ} \mathrm{C}\right)^{1}\end{array}$ & 18 & 17 & 20 & 15 & 14 & 17 & 15 & 15 & 19 \\
\hline $\begin{array}{l}\text { Maximum pool } \\
\text { temperature }\left({ }^{\circ} \mathrm{C}\right)^{1}\end{array}$ & 23 & 24 & 25 & 18 & 24 & 20 & 23 & 24 & 25 \\
\hline
\end{tabular}

${ }^{1}$ Temperature was recorded in all pools during August and September survey dates.

Table 2. Length of stream that was dry, non-pool wet, or pool, along with the average maximum depth, average mean depth, mean temperature, and maximum temperature of pools in Walaluuks Creek (formerly Squaw Creek), Washington, during surveys conducted in 2015-17.

[Abbreviations: $\mathrm{cm}$, centimeter; $\mathrm{m}$, meter; $\mathrm{m}^{2}$, square meter; $\mathrm{Rkm}$, river kilometer; ${ }^{\circ} \mathrm{C}$, degrees Celsius]

\begin{tabular}{lccc} 
& \multicolumn{3}{c}{ Walaluuks Creek Rkm 0-9 } \\
\cline { 2 - 4 } & $\mathbf{2 0 1 5}$ & $\mathbf{2 0 1 6}$ & $\mathbf{2 0 1 7}$ \\
\hline Survey dates & $9 / 24-9 / 29$ & $9 / 15-9 / 19$ & $9 / 11-9 / 15$ \\
Total stream length surveyed (m) & 9,066 & 9,303 & 8,215 \\
Length dry (m) & 5,596 & 5,350 & 3,725 \\
Percent dry & 62 & 57 & 45 \\
Length non-pool that was wet (m) & 2,257 & 3,051 & 3,424 \\
Percent non-pool wet & 25 & 33 & 42 \\
Number of pools & 45 & 51 & 60 \\
Total length of pools (m) & 1,213 & 903 & 1,067 \\
Percent pool & 13 & 10 & 13 \\
Mean pool length (m) & 27 & 18 & 18 \\
Mean pool area (m2) & 133 & 81 & 83 \\
Mean max depth of pools $(\mathrm{cm})$ & 49 & 52 & 54 \\
Average mean depth of pools $(\mathrm{cm})$ & 25 & 27 & 27 \\
Mean temperature of pools $\left({ }^{\circ} \mathrm{C}\right)^{1}$ & 14 & 14 & 16 \\
Maximum temperature of pools $\left({ }^{\circ} \mathrm{C}\right)^{1}$ & 17 & 17 & 19 \\
\hline
\end{tabular}

${ }^{1}$ Temperature was recorded in all pools during August and September survey dates. 


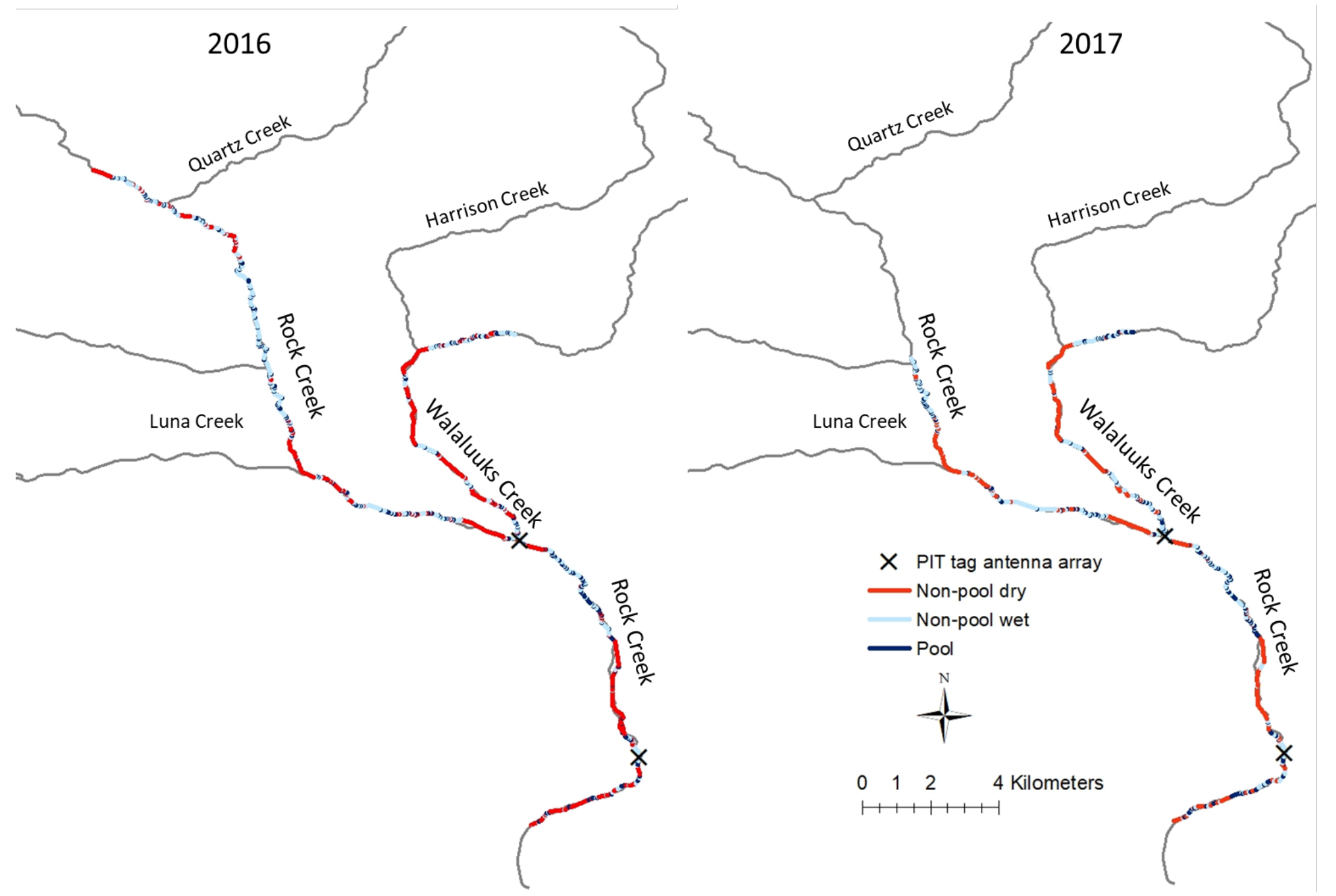

Figure 2. Schematic of Rock Creek and Walaluuks Creek, Washington showing the location and streambed sections that were non-pool dry, nonpool wet, and pool habitats during surveys in late August to September, 2016 and 2017. 


\section{Fish Sampling and Tagging}

Fish sampling occurred during autumn after habitat surveys were completed from September 26 to November 1, 2016, and October 2 to November 2, 2017. Sampling was focused on capturing juvenile salmonids and bridgelip suckers for determining species distribution, relative abundance, length-frequency (appendix 1), weights (appendix 2), and population density within selected pools. Additional sampling occurred in non-pool habitats and non-randomly selected pools to obtain additional fish for PIT tagging in order to increase sample sizes for improving survival estimates, smolt travel time estimates, and smolt to adult return estimates in the future. All PIT-tagged fish are monitored at the instream PTIS sites, RCS and RCL as well as the PTAGIS detection sites within the Columbia River Basin (table 3).

During 2016 and 2017, the total number of salmonids handled was relatively similar across years with an increase in total numbers tagged in 2017 (table 3). However, during 2017, the number of $O$. mykiss handled and PIT tagged increased. During 2016, 675 O. mykiss were handled and 454 were PIT tagged and 849 Coho salmon were handled with 459 PIT tagged. During 2017, 1,107 O. mykiss were handled and 699 were PIT tagged, with 495 Coho salmon handled and 420 PIT tagged.

Bridgelip suckers were also sampled for determining species distribution, relative abundance, length-frequency (appendix 1), weights (appendix 2), and population density within selected pools. The first year of targeting bridgelip suckers for PIT tagging was 2016, and we handled 235 fish and PIT tagged 65. During 2017, these efforts were expanded, and we handled 947 fish and PIT tagged 224 within Rock Creek and handled 50 fish and PIT tagged 19 in Walaluuks Creek (table 4). 
Table 3. Summary of Oncorhynchus mykiss and Coho salmon tagged with passive integrated transponder (PIT) tags in Rock Creek, Washington, and a tributary of Rock Creek, Walaluuks Creek, during autumn 2016 and 2017, and detections at PIT-tag Interrogation Systems in Rock Creek and the Columbia River, Washington.

[Rock Creek is a Columbia River tributary located at river kilometer (rkm) 368. Rock Creek sites are RCL at rkm 5 and RCS at rkm 13. Downstream detection sites (out-migration) in the Columbia River were JDJ , John Day Dam juvenile bypass (rkm 347); B2J, Bonneville Dam juvenile bypass (rkm 234); BCC, Bonneville Dam corner collector (rkm 234); TWX, PIT-tag detection trawl operated at the Columbia River estuary (rkm 75); ESANIS, East Sand Island bird colony (morts; rkm 8); LMILIS, Little Miller Island bird colony (morts; rkm 331). Adult detection sites (in-migration) in the Columbia River were BON, Bonneville Dam adult fish ladders; TD1, The Dalles Dam adult fish ladders (rkm 308). Detection information current to July 3, 2018.

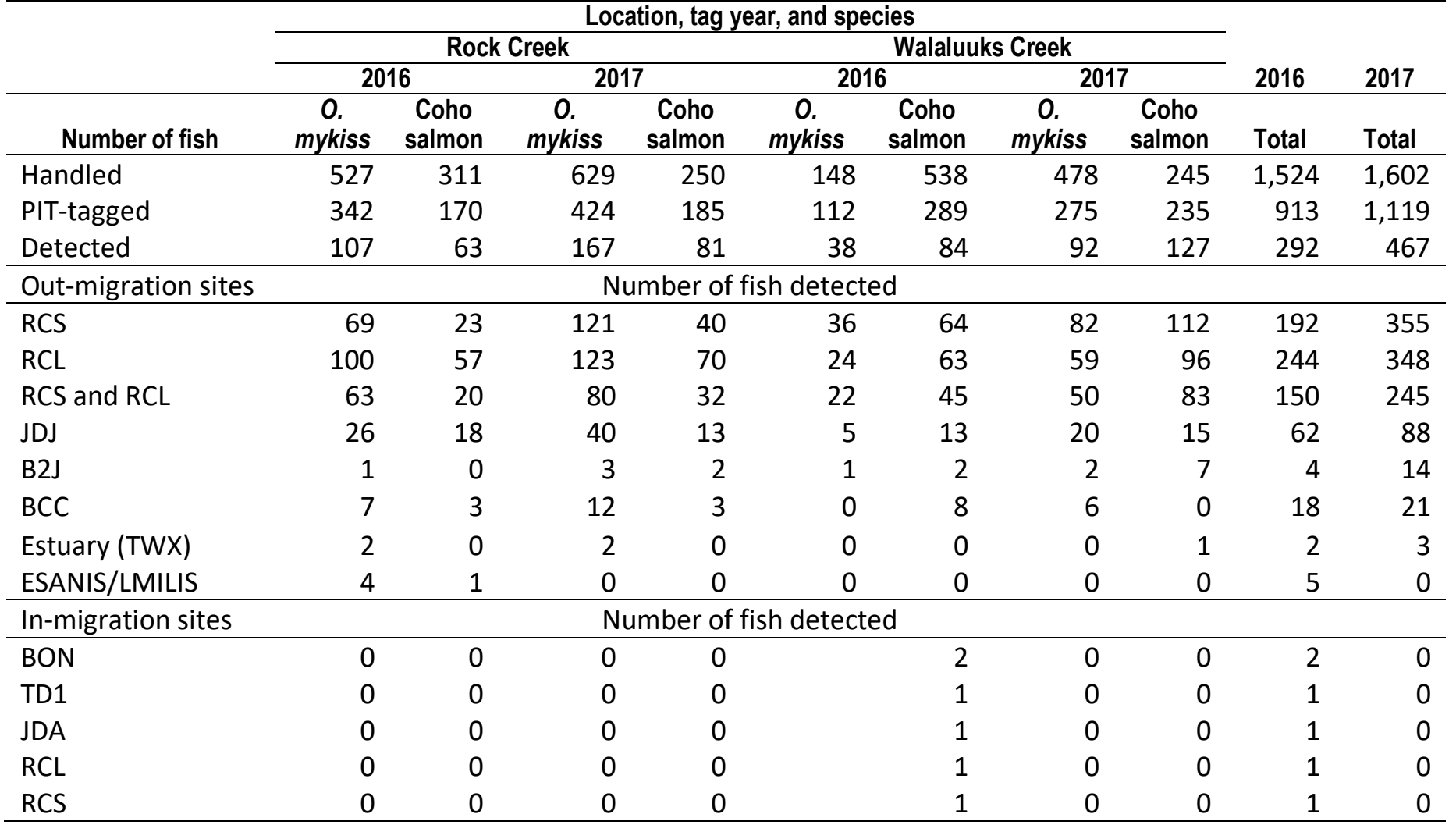


Table 4. Summary of bridgelip (Catostomus columbianus) and largescale sucker (C. macrocheilus) tagged with passive integrated transponders (PIT) in Rock Creek, Washington, and a tributary of Rock Creek, Walaluuks Creek, during autumn 2016 and 2017, and detections at PIT-Tag Interrogation Systems in Rock Creek, Washington.

[Rock Creek is a Columbia River tributary located at river kilometer (rkm) 368, the two sites on Rock Creek are RCL at rkm 5 and RCS at rkm 13. No bridgelip suckers were tagged in Walaluuks Creek in 2016. Detection information is up to date to July 3, 2018. Abbreviations: BLS, bridgelip sucker; LSS, largescale sucker; RKM, river kilometer]

\begin{tabular}{|c|c|c|c|c|c|c|c|c|}
\hline \multicolumn{8}{|c|}{ Tag year, release location, and species } & \multirow[b]{4}{*}{ Total } \\
\hline & \multicolumn{6}{|c|}{ Rock Creek } & $\begin{array}{c}\text { Walaluuks } \\
\text { Creek }\end{array}$ & \\
\hline & \multicolumn{3}{|c|}{2016} & \multicolumn{3}{|c|}{2017} & 2017 & \\
\hline Release RKM & $0-4$ & $5-13$ & $14-21$ & $0-4$ & $5-13$ & $14-21$ & $0-4$ & \\
\hline $\begin{array}{l}\text { Number of } \\
\text { fish }\end{array}$ & BLS & BLS & BLS & BLS & BLS & BLS/LSS & BLS & BLS/LSS \\
\hline Handled & 134 & 99 & 2 & 670 & 171 & 106 & 50 & 1,232 \\
\hline PIT-tagged & 49 & 14 & 2 & 141 & 48 & 35 & 19 & 308 \\
\hline Detected & 2 & 10 & 1 & 0 & 26 & 22 & 12 & 73 \\
\hline \multicolumn{9}{|l|}{ Detection sites } \\
\hline $\mathrm{RCS}$ & 0 & 0 & 0 & 0 & 4 & 14 & 11 & 29 \\
\hline RCL & 2 & 10 & 1 & 0 & 26 & 19 & 9 & 67 \\
\hline RCS and RCL & 0 & 0 & 0 & 0 & 4 & 11 & 8 & 23 \\
\hline
\end{tabular}

\section{Non-Target Fish Species Distribution}

Species distribution for non-target species were also documented. Speckled dace (Rhinichthys osculus), red side shiners (Richardsonius balteatus), and sculpin (Cottidae) were found throughout the sampling area, with dace being abundant in most pools. Bridgelip suckers were also captured throughout the system, and pool population abundance estimates were calculated where possible and are presented in the section below. Largescale suckers $(C$. macrocheilus) were captured much less frequently and both suckers were more common in the lower section of Rock Creek. The lower Rock Creek section had the highest diversity of species. Additional species included northern pikeminnow (Ptychocheilus oregonensis), smallmouth bass (Micropterus dolomieu), and bluegill (Lepomis macrochirus), which were captured in pools downstream of rkm 5. Bluegill were only observed in 2016, in a larger pool at rkm 4.5, where at least three were captured. This species typically prefers warmer water from 16 to $27^{\circ} \mathrm{C}$ (60 to $\left.80^{\circ} \mathrm{F}\right)$. Very few salmonids were captured in this pool. 


\section{Pool Population Estimates}

During 2016, 33 pools were identified with maximum depths greater than or equal to 70 $\mathrm{cm}$ from rkm 2 to 22 on Rock Creek. Of these, 10 were selected as potential candidates for sampling using a systematic sample design (starting with the second pool, and every third pool after that). Some pools originally selected were not sampled due to equipment failure timing or the pool was deemed too large to sample effectively with the crew and equipment available. Alternate pools were selected until at least eight pools were sampled. One additional pool was opportunistically sampled (rkm 11.5), and additional pools were added due to block net failures, because it was necessary for pools to be "closed." As a result, 11 pools were sampled to estimate abundance of O. mykiss, Coho salmon, and bridgelip suckers in Rock Creek during 2016 (fig. 3). However, the uppermost three pools did not maintain a closed population between sampling days, due to net failures with increased river flows and leaf litter. These estimates were adjusted for any fish that were known to have moved out of the population by electrofishing the reaches immediately upstream and downstream of the pool. However, we do not know how many unmarked fish moved into or out of the system between our sample days. We have provided these estimates as reference knowing that the closed population assumption was violated.

For Walaluuks Creek, four pools (maximum depths greater than or equal to $60 \mathrm{~cm}$ ) were selected based on a systematic, sample design and two additional index pools were selected during 2016. Of these, five pools were sampled for population pool abundance estimates (fig. 3) due to sampling time constraints.

During 2017, similar sample design criteria were used with a systematic sample design approach (starting with the second pool and every fourth after that), in addition to selecting a few pools as index sites to compare to the 2016 sampling efforts. The maximum pool depths of candidate pools to sample was greater than or equal to $65 \mathrm{~cm}$. This was adjusted lower during 2017 in order to allow all pools that had been sampled during 2016 to be available to selection through the systematic random sample design. During 2017, 43 pools were identified as candidates for sampling. Eight pools were sampled in Rock Creek during 2017 to estimate population abundances (fig. 3). We did not have any major net failures during 2017, which means the closed-population assumption was met. However, we did have one beaver-sized hole appear in a net over night and on a few occasions marked fish were found in reaches immediately upstream or downstream of the sampled pool. Pool abundance estimates were adjusted in these cases to remove any marked fish found outside of the pool. For Walaluuks Creek, seven pools were sampled to estimate population abundances (fig. 3). 


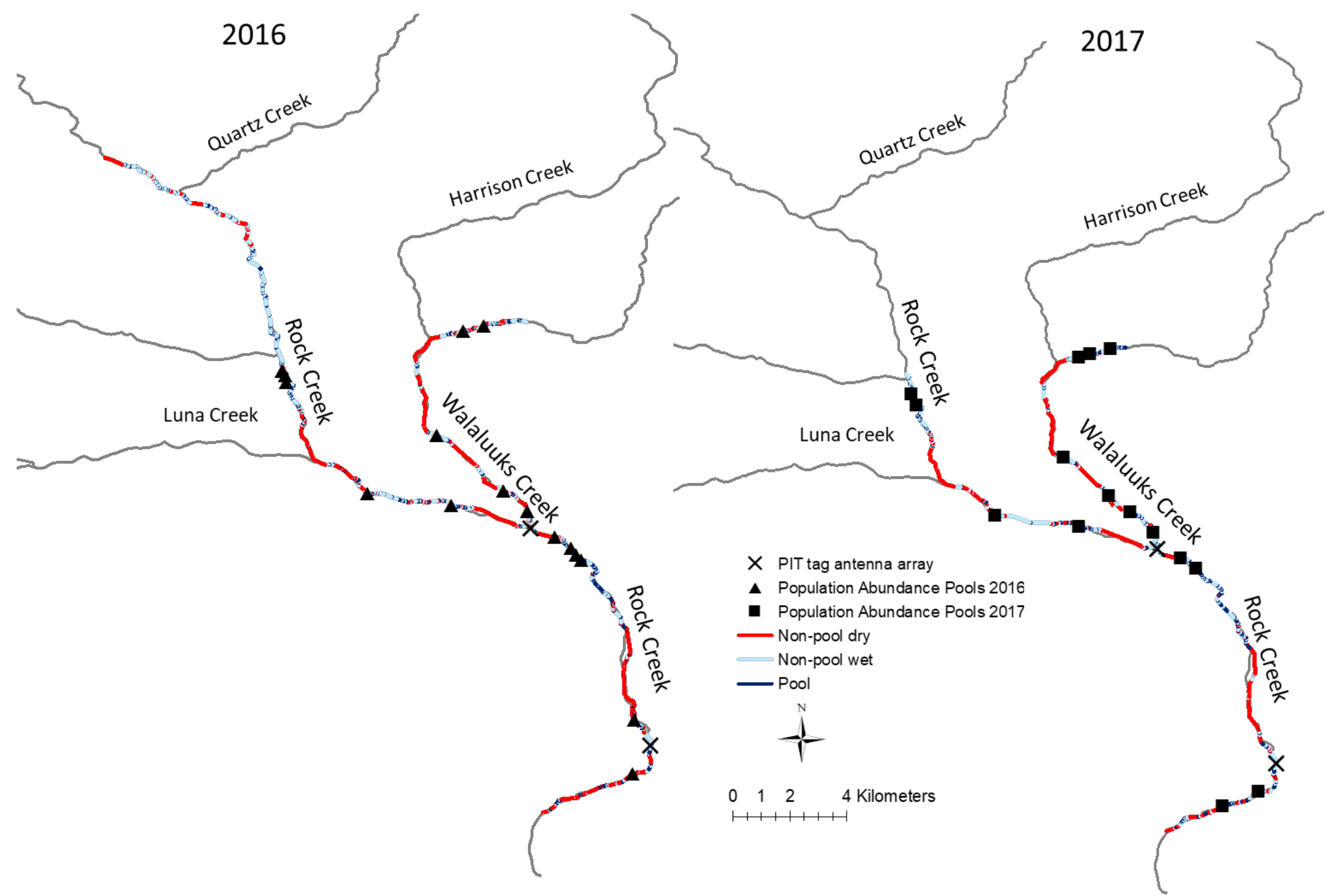

Figure 3. Schematic of Rock Creek and Walaluuks Creek, Washington showing the location and streambed sections that were non-pool dry, nonpool wet, and pool habitats during surveys in late August to September, and pool abundance estimate locations sampled during 2016 and 2017. 
O. mykiss pool abundance estimates varied longitudinally (downstream to upstream), among age classes, and across years (fig. 4). Very few $O$. mykiss were captured downstream of rkm 5 during 2016 or 2017 in Rock Creek. Age-0 O. mykiss were generally more abundant than age-1 fish (fig. 4). Rock Creek pool abundances for age-0 O. mykiss were estimated for 11 pools during 2016 with an average density of 0.236 (range: $0.007-0.692$ ) fish per $\mathrm{m}^{2}$. During 2017 , pool abundances for age- 0 O. mykiss were estimated for six of the eight pools sampled, for an average density of 0.208 (range: $0.003-0.341$ ) fish per $\mathrm{m}^{2}$, which was lower than 2016. Pools in which estimates were not calculated either had too few fish captured to calculate a markrecapture estimate or no $O$. mykiss were captured for that age class. The pool at rkm 3.5 had zero age-0 $O$. mykiss captured, and one age- 0 was captured from the pool at rkm 4.5. For age- $O$. mykiss, pool abundances were estimated for 5 of the 11 pools sampled during 2016 (fig. 4). No age-1 O. mykiss were collected from pools at rkm 6 and 11.3 and too few were marked and recaptured from pools at rkm 11.5, 11.8, 14.7, and 21.1. The average pool density $(\mathrm{n}=5)$ of age-1 O. mykiss for 2016 was 0.014 (range: $0.002-0.038$ ) fish per $\mathrm{m}^{2}$, which was lower than the average pool density $(n=5)$ for 2017 of 0.048 (range: $0.004-0.120)$ fish per $\mathrm{m}^{2}$ (fig. 4). During 2017, no age-1 O. mykiss were collected from pools at rkm 4.5 and 12.3 , and only one was captured from the pool at rkm 3.5.

For Walaluuks Creek, five and seven pools were sampled during 2016 and 2017 to estimate $O$. mykiss pool abundance. Pool abundance estimates varied greatly across years among pools (fig. 5). Age-0 O. mykiss were more abundant than age-1 in all pools sampled except one during 2016 ( $\mathrm{rkm} \mathrm{8.3,} \mathrm{fig.} \mathrm{5).} \mathrm{The} \mathrm{average} \mathrm{pool} \mathrm{abundance} \mathrm{densities} \mathrm{for} \mathrm{age-0} \mathrm{O.} \mathrm{mykiss} \mathrm{were}$ 0.339 (range: $0.023-0.891$ ) and 0.967 (range: 0.122-2.299) fish per $\mathrm{m}^{2}$ for 2016 and 2017. For age-1 O. mykiss during 2016, no fish were captured at the two lowest pools (rkm 0.5 and 1.4) sampled. The average pool abundance density for the three remaining pools was 0.204 (range: 0.028-0.472) fish per m2. During 2017, age-1 O. mykiss were captured in all pools sampled, but too few were captured at rkm 7.1 to calculate a pool abundance estimate (fig. 5). The average pool abundance for the six pools was 0.134 (range: $0.023-0.324$ ) fish per $\mathrm{m}^{2}$.

Coho salmon population abundance estimates were highly variable across years for pools in both Rock Creek (fig. 6) and Walaluuks Creek (fig. 7). Higher fish densities were estimated for the sampled pools during 2016 than during 2017 (figs. 6 and 7). Coho salmon were captured throughout most of the area sampled during both years; however, during 2017 Coho salmon were not captured in the uppermost Walaluuks pools where population abundance sampling occurred. Additional fish sampling in that year captured two Coho salmon that documented persistent presence within the uppermost section (rkm 8) of Walaluuks Creek during 2016 and 2017.

During 2016, Coho salmon abundance estimates were calculated for 6 of the 11 pools sampled in Rock Creek for an average density of 0.821 (range: $0.017-3.639$ ) fish per $\mathrm{m}^{2}$ (fig. 6). No Coho salmon were captured in pools at rkm 6, 11.8, 20.8, and 21.1, and one was captured at the pool at rkm 21.2 in Rock Creek. During 2017, abundance estimates were calculated for 6 of the 8 pools sampled in Rock Creek for an average density of 0.237 (range: 0.001-0.661) fish per $\mathrm{m}^{2}$. During 2016, Coho salmon population estimates were calculated for all pools $(\mathrm{n}=5)$ sampled in Walaluuks Creek for an average density of 1.793 (range: $0.185-3.679$ ) fish per $\mathrm{m}^{2}$. During 2017, population abundance estimates were calculated for 4 of the 7 pools sampled in Walaluuks Creek, with an average density of 0.421 (range: $0.185-0.797$ ) fish per $\mathrm{m}^{2}$. No Coho salmon were captured in the upper Walaluuks Creek pools sampled for abundance during 2017 (fig. 7). 

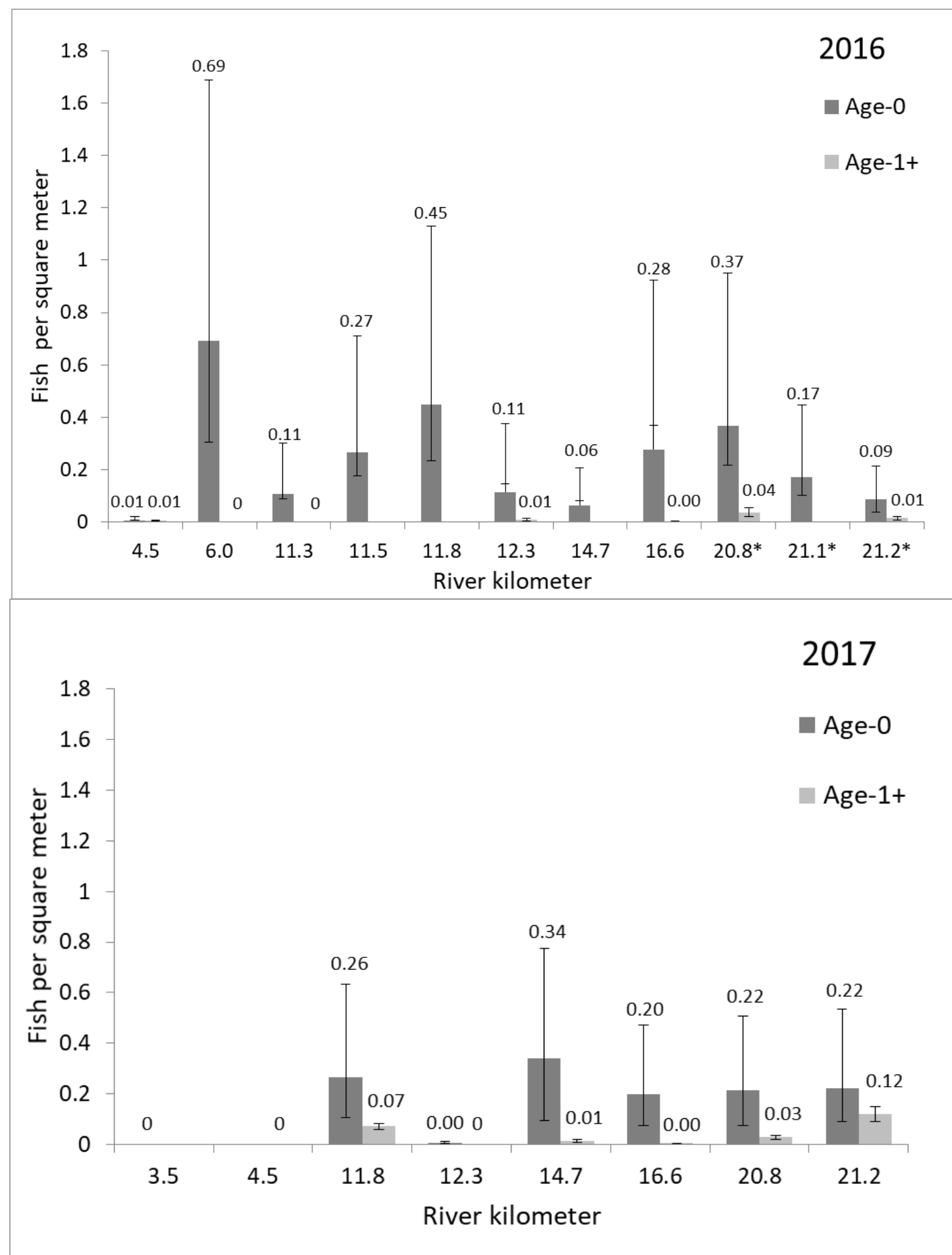

Figure 4. Graphs showing the number of age- 0 and age- 1 or older (fork length greater than 110 millimeter) Oncorhynchus mykiss per square meter during autumn 2016 and 2017 in Rock Creek, Washington. [Error bars indicate 95 percent confidence intervals. Blank values indicate too few fish were captured to calculate abundance and 0 values indicate no fish were captured, an asterix $\left({ }^{*}\right)$ indicates a net failure and non-closed population.] 


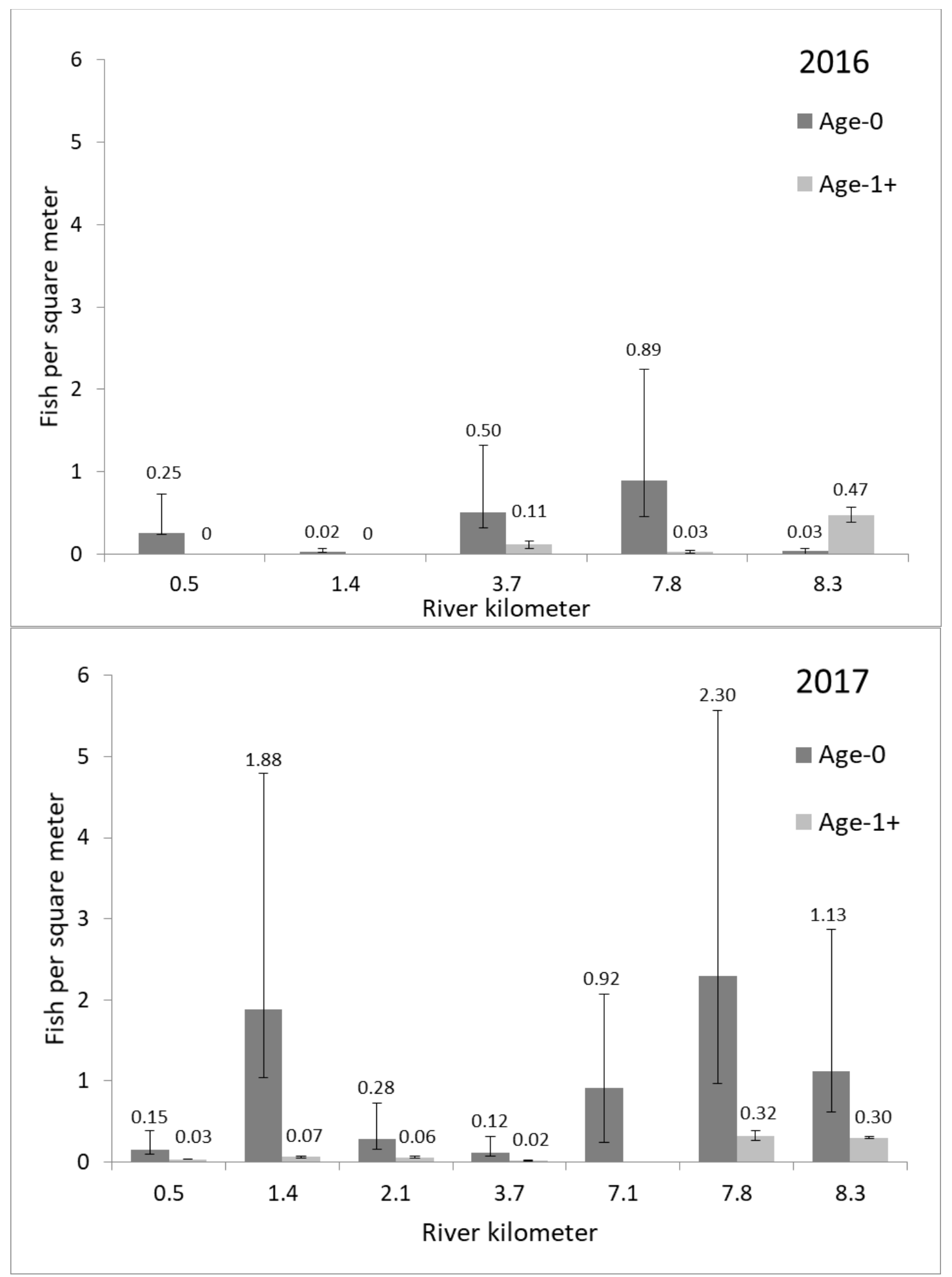

Figure 5. Graphs showing the number of age- 0 and age- 1 or older (fork length greater than 110 millimeters) Oncorhynchus kisutch per square meter during autumn 2016 and 2017 in Walaluuks Creek, Washington. [Error bars indicate 95 percent confidence intervals. Blank values indicate too few fish were captured to calculate abundance, and 0 values indicate no fish were captured of that age class.] 


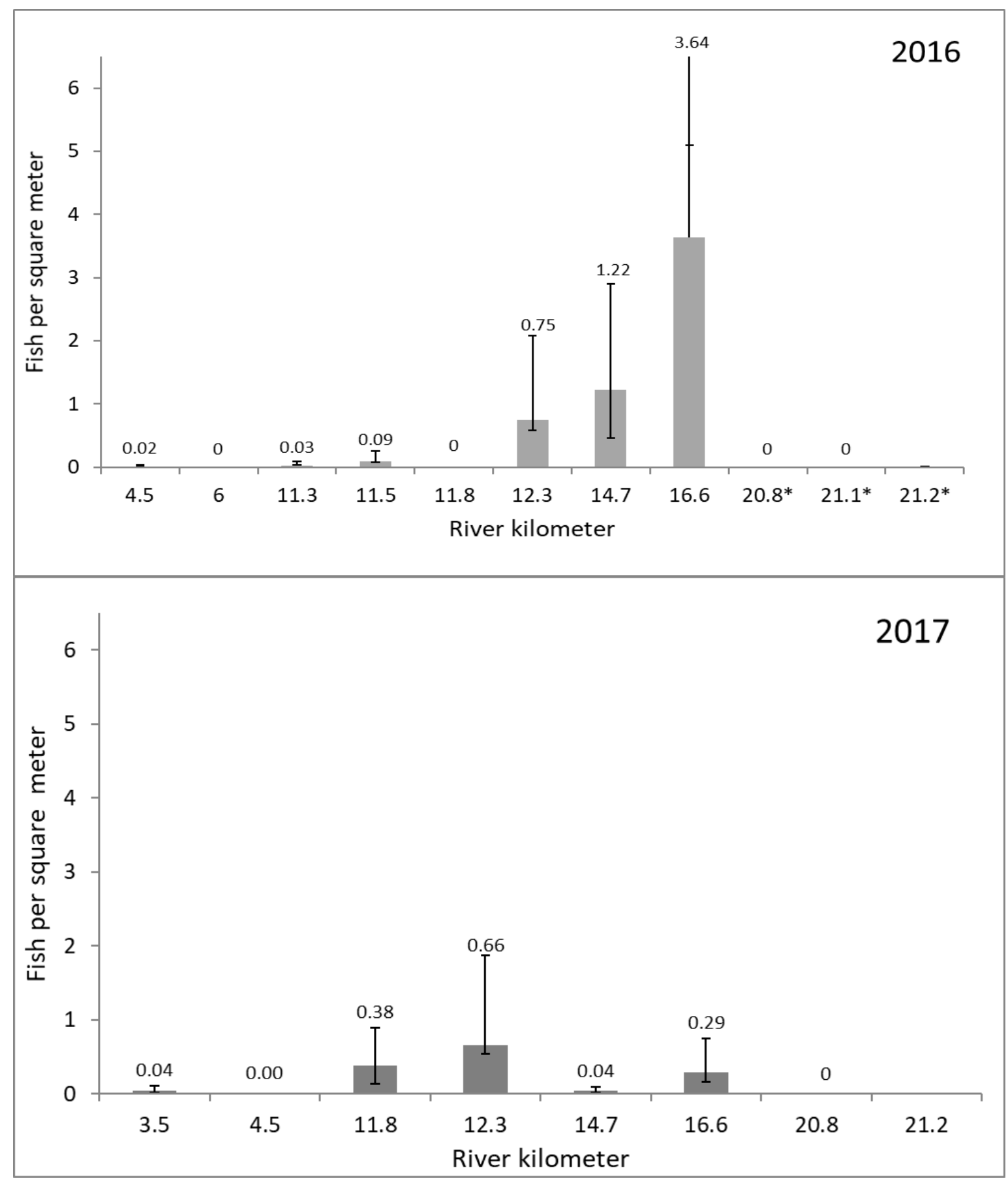

Figure 6. Graphs showing the number of Coho salmon (Oncorhynchus mykiss) per square meter during autumn 2016 and 2017 in Rock Creek, Washington. [Error bars indicate 95 percent confidence intervals. Blank values indicate too few fish were captured to calculate abundance and 0 values are where no Coho salmon were captured, an asterix $\left({ }^{*}\right)$ indicates a net failure and potential non-closed population.] 


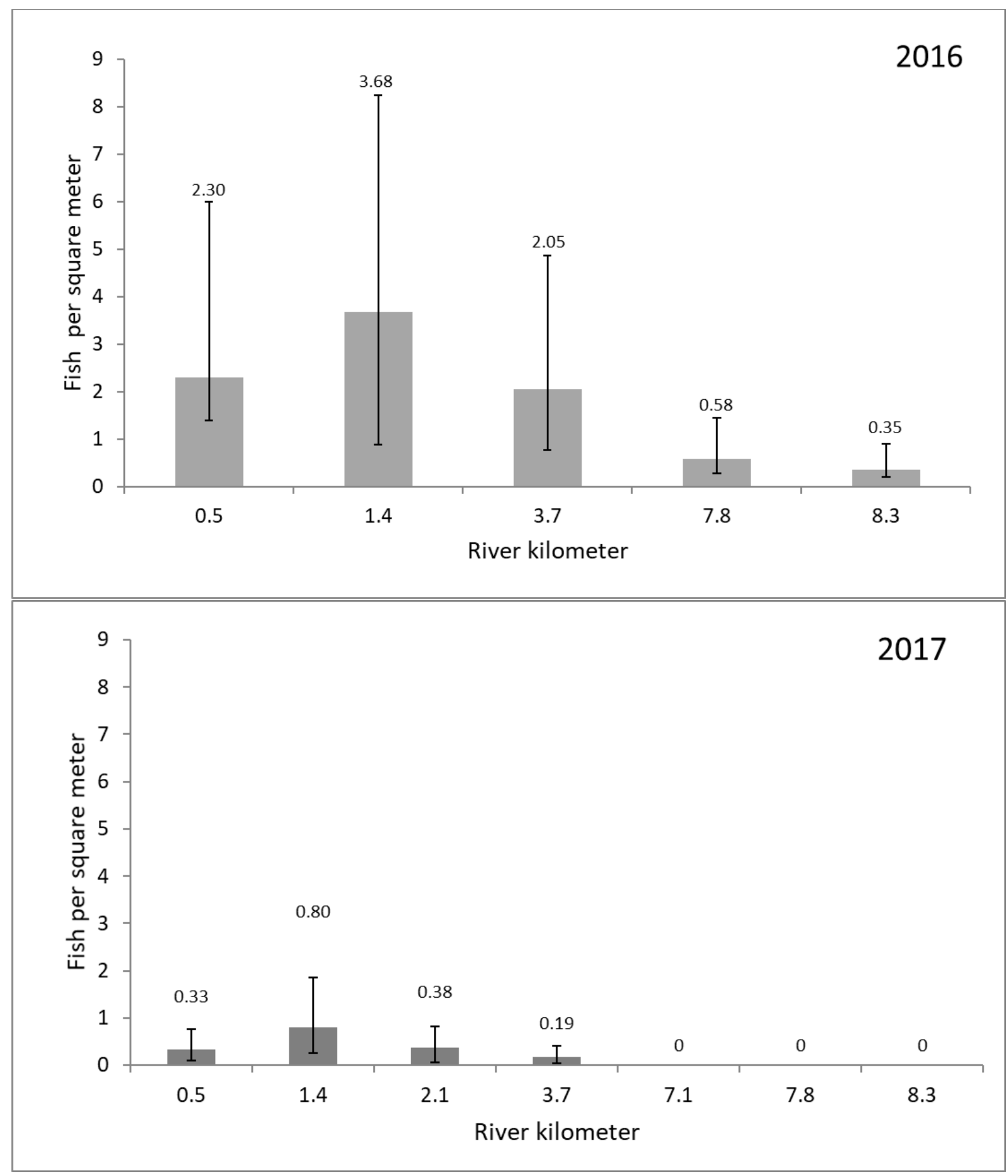

Figure 7. Graphs showing the number of Coho salmon (Oncorhynchus kisutch) per square meter during autumn 2016 and 2017 in Walaluuks Creek, Washington. [Error bars indicate 95 percent confidence intervals. The 0 values indicate no Coho salmon were captured in that pool.] 
Bridgelip sucker pool abundance estimates were calculated in Rock Creek (fig. 8) during 2016 and 2017 and in Walaluuks Creek during 2017 (fig. 9). Bridgelip suckers were more frequently found in Rock Creek in higher numbers in pools downstream of Walaluuks Creek confluence. There was high variability in pool abundance estimates across years (fig. 8). During 2016, the mean pool abundance estimate was 0.171 (range: $0.003-0.757)$ fish per $\mathrm{m}^{2}(\mathrm{n}=6)$, which was lower than the 2017 mean pool abundance estimate of 1.197 (range: 0.059-3.378) fish per $\mathrm{m}^{2}(\mathrm{n}=6)$ in Rock Creek. The mean pool abundance in Waluluuks Creek was 0.045 (range: $0.003-0.109)$ fish per $\mathrm{m}^{2}(\mathrm{n}=4)$.

Pool population abundance estimates were also calculated for smallmouth bass in one pool in 2016 and two pools in 2017 where they were present. During 2016, the population abundance estimate for smallmouth bass in the pool near Rock Creek rkm 4.5 was 77 (95 percent confidence interval 45-109; $\mathrm{SE}=16.2$ ), which was 0.064 fish per $\mathrm{m}^{2}$. This was higher than the abundance estimate in the same pool during 2017, which was 35 (95 percent confidence interval 13-57; $\mathrm{SE}=10.8$ ) and 0.037 fish per $\mathrm{m}^{2}$. Multiple age classes of smallmouth bass were captured, with a FL range from 44 to $211 \mathrm{~mm}$ in 2016 and 66 to $270 \mathrm{~mm}$ in 2017 . The additional pool sampled during 2017, near rkm 3.5, had a smallmouth bass abundance estimate of 58 (95 percent confidence interval 23-93; $\mathrm{SE}=17.6$ ) and 0.149 fish per $\mathrm{m}^{2}$. The FL of fish captured ranged from 50 to $240 \mathrm{~mm}$. 

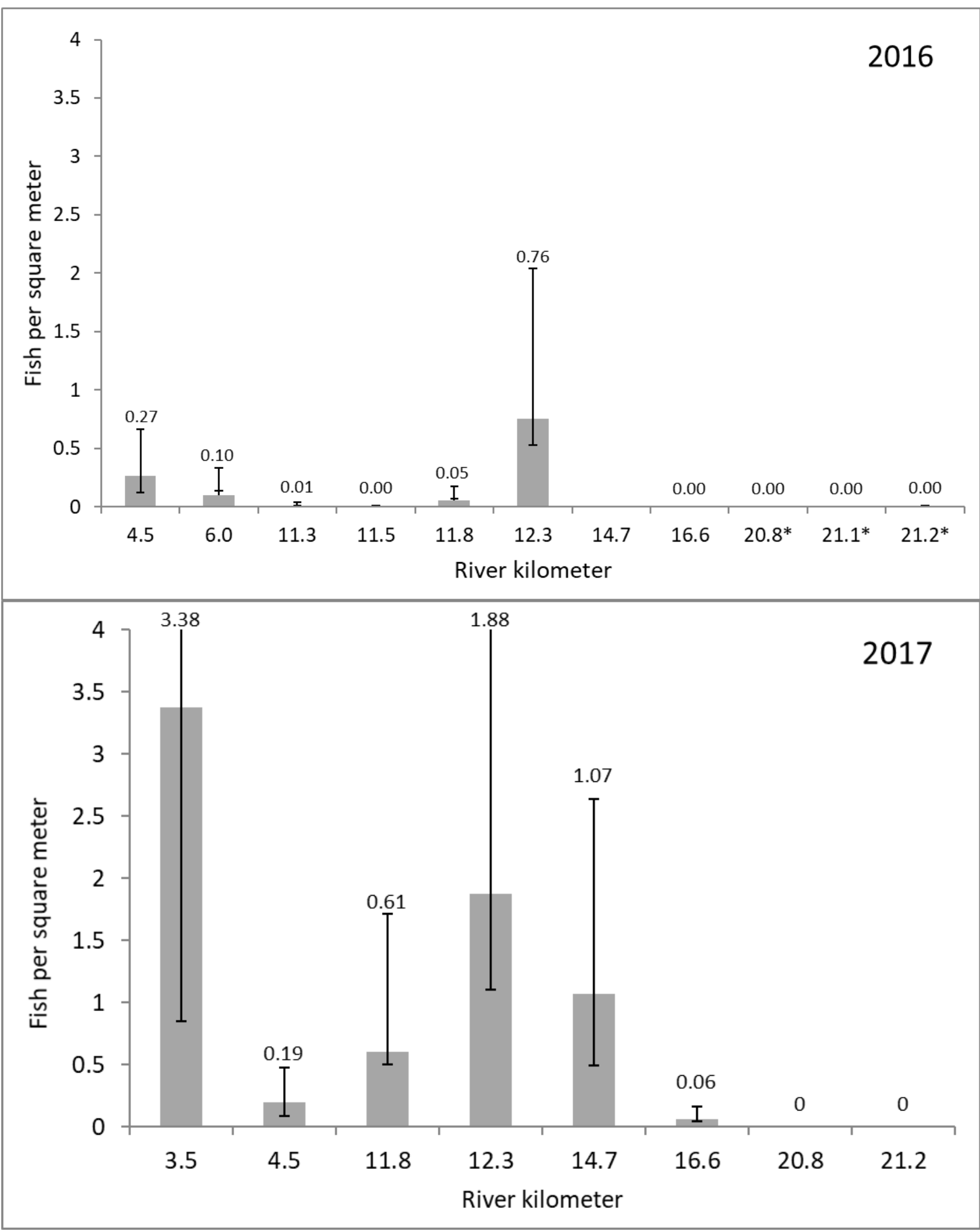

Figure 8. Graphs showing the number of bridgelip sucker (Catostomus columbianus) per square meter during autumn 2016 and 2017 in Rock Creek, Washington. [Error bars indicate 95 percent confidence intervals. Blank values indicate too few fish were captured to calculate abundance and 0 values are where 0 fish were captured, an asterix $\left(^{*}\right)$ indicates a net failure and potential non-closed population.] 


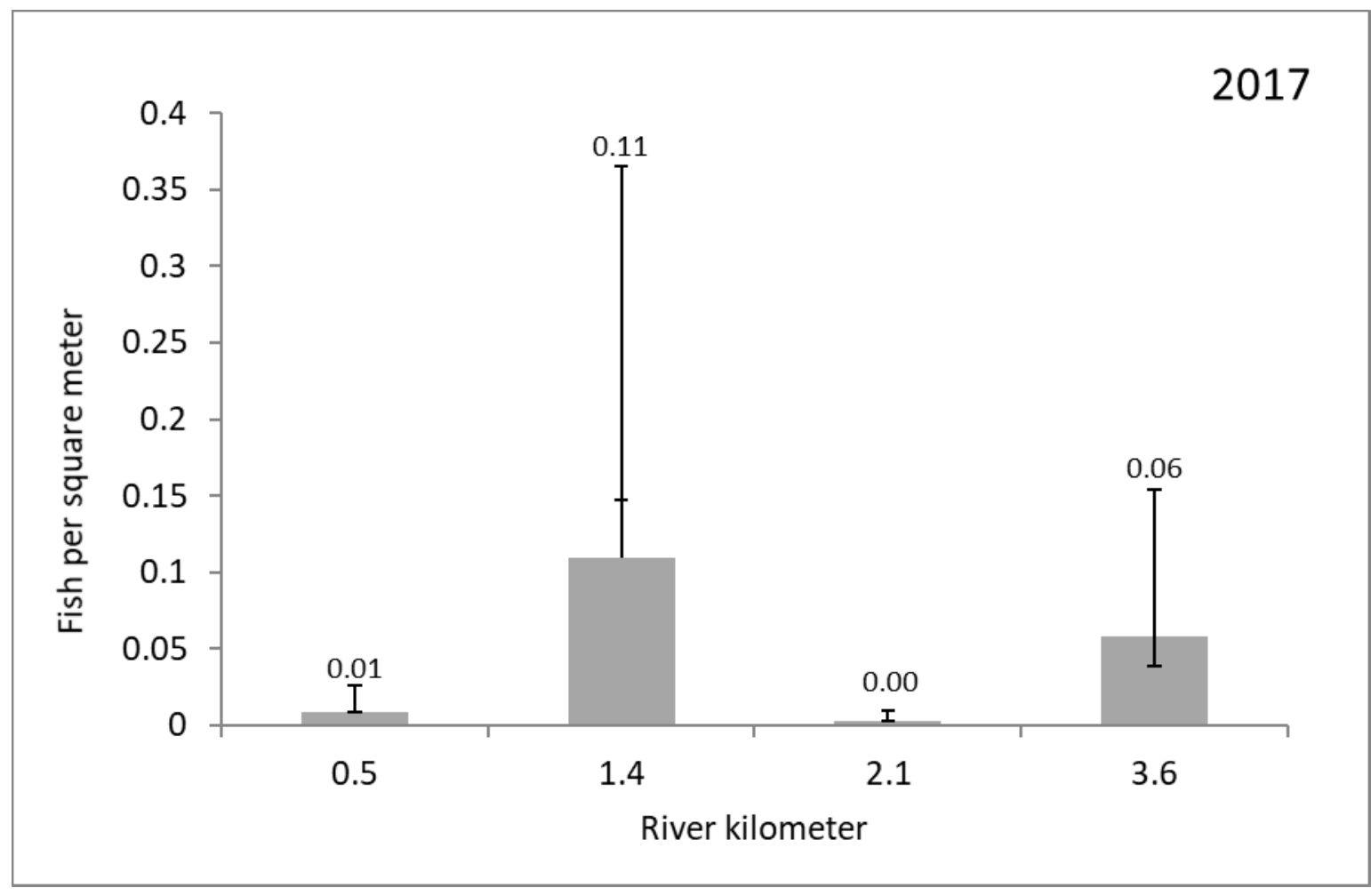

Figure 9. The number of bridgelip sucker (Catostomus columbianus) per square meter during autumn 2017 in Walaluuks Creek, Washington. [Error bars indicate 95 percent confidence intervals.]

For northern pikeminnow, population abundance estimates were calculated for two pools during 2017. During 2016, 116 Northern Pikeminnow were captured at the pool near rkm 4.5, but fish were not marked. Fish captured during 2016 ranged from 45 to $215 \mathrm{~mm}$ FL. During 2017, Northern Pikeminnow were marked using a fin clip if they were greater than $90 \mathrm{~mm}$ FL in the pool near rkm 4.5. From this effort the population estimate was 36 ( 95 percent confidence interval 26-46; $\mathrm{SE}=5.1$ ) and 0.038 fish per $\mathrm{m}^{2}$ for northern pikeminnow greater than $90 \mathrm{~mm}$. Additional northern pikeminnow were captured with a FL range between 35 and $50 \mathrm{~mm}$, but since recapture rates on fish in this size range are typically low and they are not a target species for generating abundance estimates, we did not mark these fish. Northern pikeminnow were captured and marked in the pool near rkm 3.5. Fish ranged in FL size from 48 to $80 \mathrm{~mm}$. The pool abundance estimate was 167 (95 percent confidence interval $19-315 ; \mathrm{SE}=74$ ) and 0.430 fish per $\mathrm{m}^{2}$.

Fish abundance densities were combined for all species and plotted by pool across years for comparison (figs. 10 and 11). Nonsalmonids were dominant in pools downstream of rkm 5 in Rock Creek (fig. 10). Coho salmon were the most abundant species in the middle pools during 2016 and were rare in the pools upstream of rkm 20. O. mykiss were found in all pools during 2016 in Rock Creek. During 2017, more bridgelip suckers were observed throughout the study area and were the most abundant species in pools between rkm 4.5 and 14.7. In Walaluuks Creek, Coho salmon were the most abundant species in pools downstream of rkm 4 (fig. 11) during 2016. During 2017, O. mykiss were found in more equal numbers to the Coho salmon in these same pools and were the dominant species in the upper pools. 


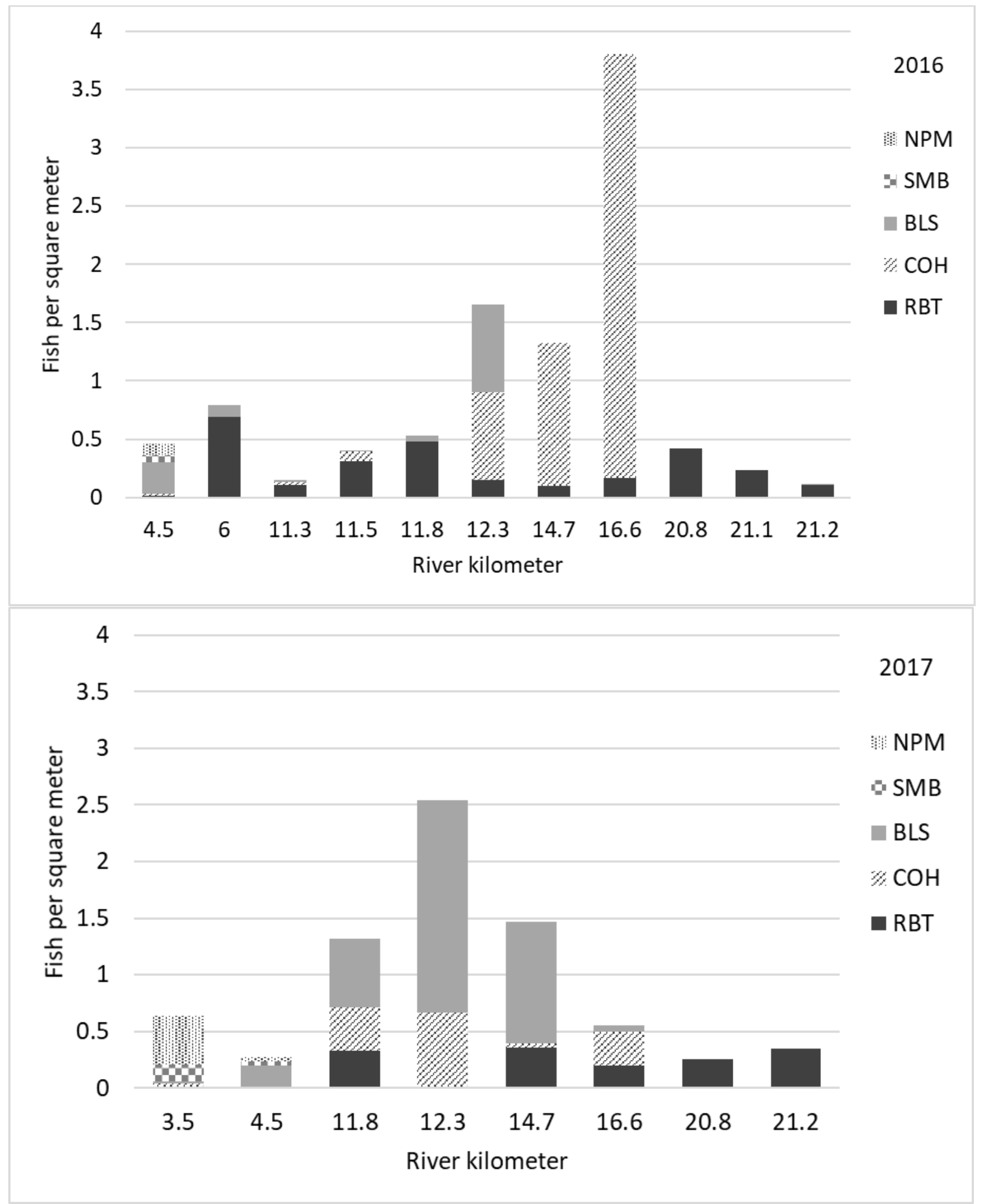

Figure 10. Graphs showing pool population abundance estimates for the number of fish per square meter $\left(\mathrm{m}^{2}\right)$ electrofished during autumn 2016 and 2017 in Rock Creek, Washington. [NPM, northern pikeminnow (Ptychocheilus oregonensis); SMB, smallmouth bass (Micropterus dolomieu); BLS, bridgelip suckers (Catostomus columbianus); $\mathrm{COH}$, Coho salmon (Oncorhynchus kisutch); RBT, O. mykiss.] 


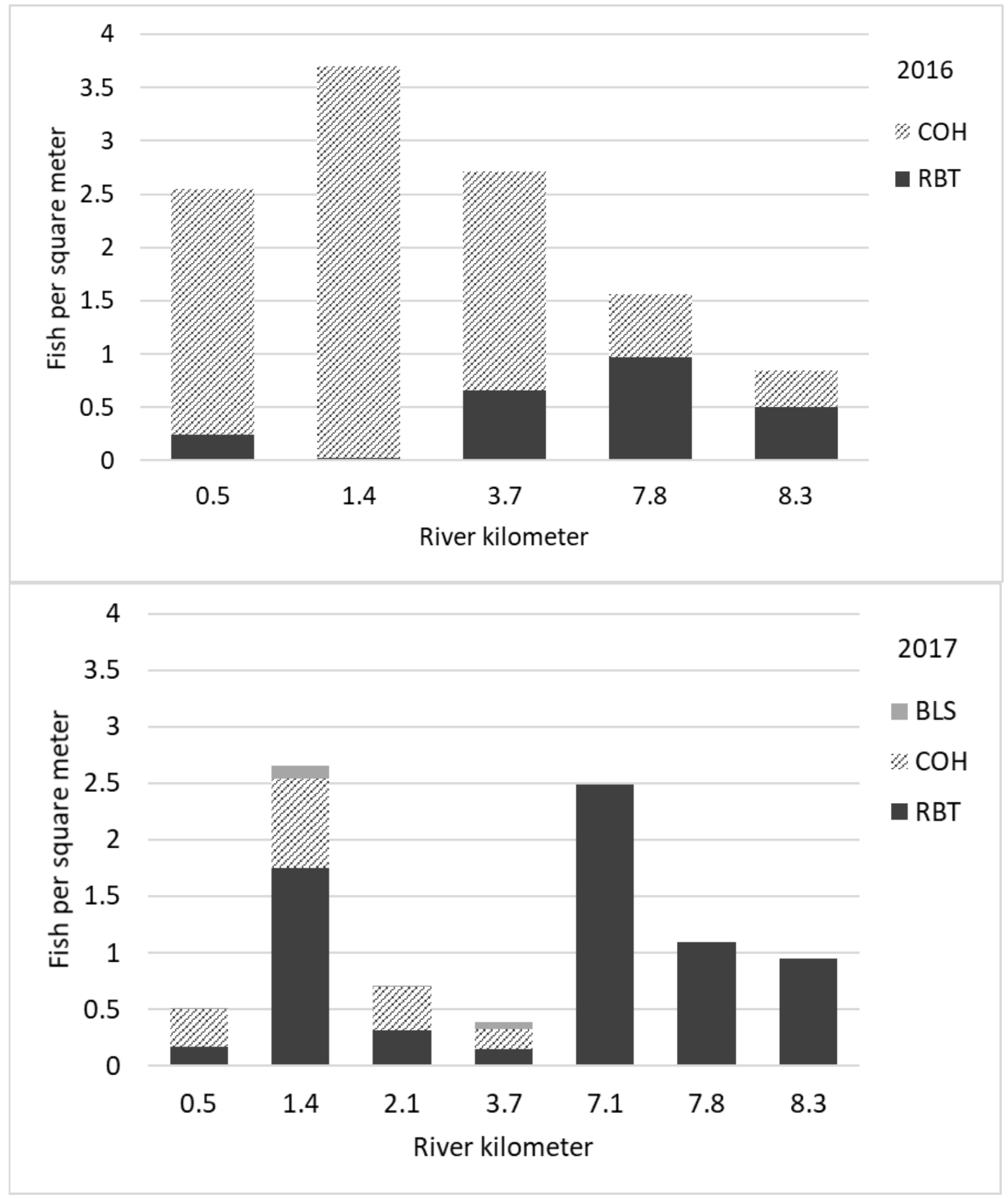

Figure 11. Graph showing pool population abundance estimates for the number of fish per square meter $\left(\mathrm{m}^{2}\right)$ electrofished during autumn 2016 and 2017 in Walaluuks Creek, Washington. [BLS, bridgelip suckers (Catostomus columbianus); $\mathrm{COH}$, Coho salmon (Oncorhynchus kisutch); RBT, O. mykiss.] 


\section{Condition Factor}

A mean condition factor was calculated for O. mykiss, Coho salmon, and bridgelip suckers within habitat reaches throughout the study area. Habitat reaches included pools for abundance estimates, as well as additional pools and non-pool wet sections. A mean condition factor was not calculated for habitat reaches where only one fish of a species was captured. For age-0 O. mykiss collected in Rock Creek, mean condition factor was 1.11 (range: 0.99-1.23) in 2016 and 1.14 (range: 0.97-1.27) in 2017 (fig. 12). For age-1+O. mykiss collected in Rock Creek, mean condition factor was 1.06 (range: 0.99-1.19) for 2016 and 1.08 (range: 1.00-1.27) for 2017. Condition factors were similar across habitat units (pools) which were sampled for population abundance and reaches (includes non-pool wet and pools) that were not (fig. 12). In Rock Creek, higher mean condition factors occurred in the uppermost habitat reaches for age-0 O. mykiss. For age-0 O. mykiss collected in Walaluuks Creek, mean condition factor was 0.91 (range 0.52-1.07) for 2016 and 1.05 (range: 0.90-1.24) for 2017. For age-1+ O. mykiss, collected in Walaluuks Creek mean condition factor was 1.03 (range 0.97-1.07) for 2016 and 1.06 (range: 1.00-1.12) for 2017. Higher condition factors were in the upstream reaches for age0 O. mykiss (fig. 13). Condition factors for Coho salmon were variable across pools (fig. 14). For Coho salmon collected in Rock Creek, mean condition factor was 1.13 (range: 1.04-1.21) for 2016 and was 1.23 (range: 0.94-1.49) for 2017. For Coho salmon collected in Walaluuks Creek, mean condition factor was 1.13 (range: $0.96-1.35$ ) for 2016 and was 1.23 (range: 1.13-1.45) for 2017. For young of year (less than $100 \mathrm{~mm}$ ) bridgelip suckers collected in Rock Creek mean condition factor was 1.32 (range: 1.25-1.37) for 2016 and 1.23 (range: 1.17-1.33) for 2017 (fig. 15 ) and for fish collected in Walaluuks Creek the mean condition factor was 1.09 (range: $1.02-1.15$ ) for 2017. 

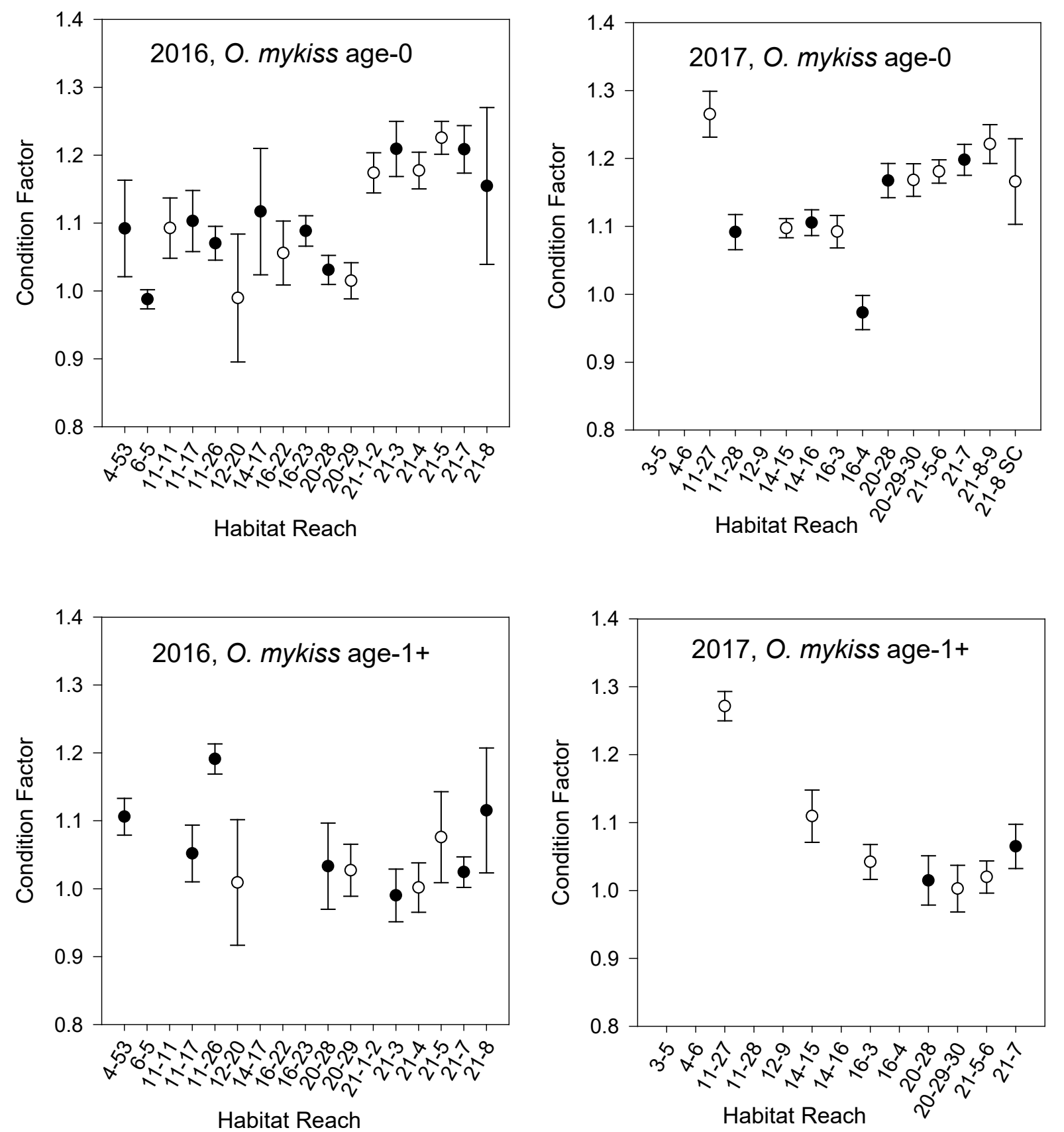

Figure 12. Graphs showing Fulton's condition factor and standard error for age-0 (less than 110 millimeters) and age 1+ Oncorhynchus mykiss captured by electrofishing in Rock Creek, Washington during autumn 2016 and 2017. [Dark circles are pools in which population abundance was estimated and open circles are pools and non-pool wet reaches. Habitat Reach indicates the river kilometer and the number count of the habitat unit consecutively counting downstream to upstream. SC indicates a side channel off the main river channel.] 


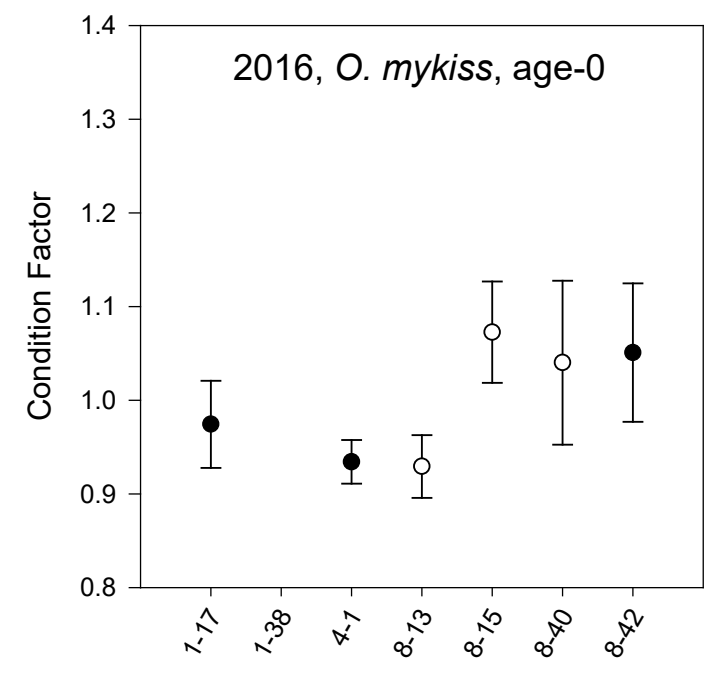

Habitat Reach

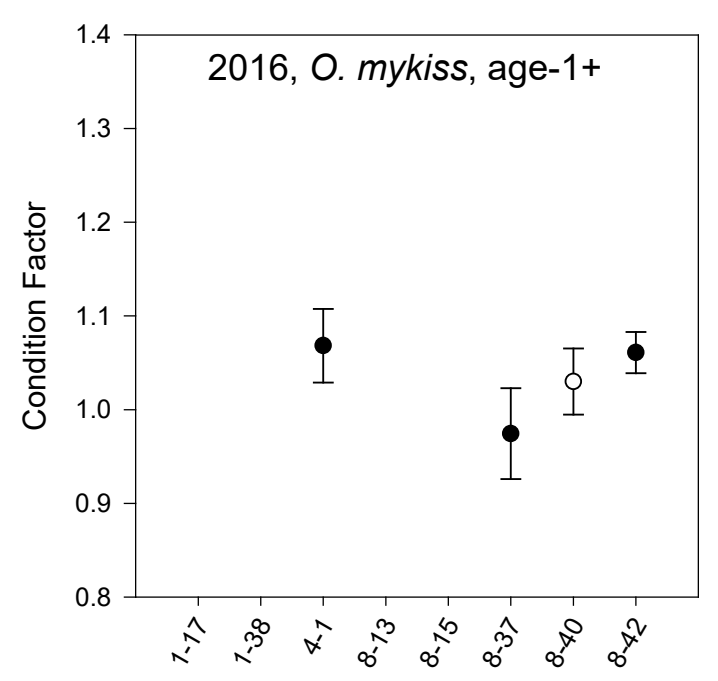

Habitat Reach

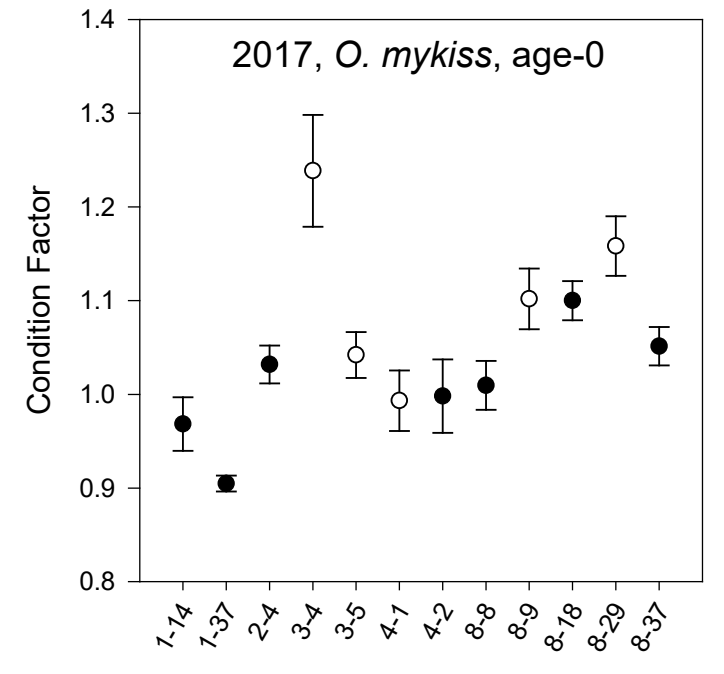

Habitat Reach

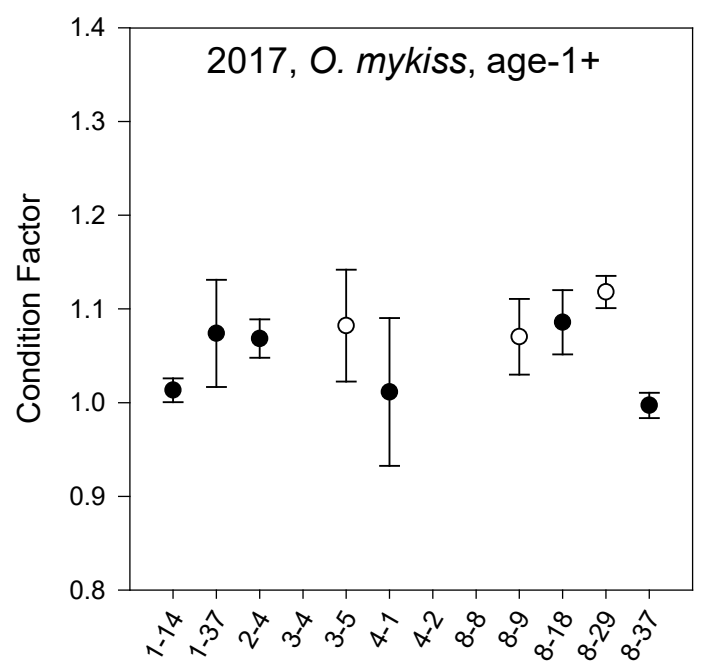

Habitat Reach

Figure 13. Fulton's condition factor and standard error for age-0 (less than $110 \mathrm{~mm}$ ) and age 1+ Oncorhynchus mykiss captured by electrofishing in Walaluuks Creek, Washington, during autumn 2016 and 2017. [Dark circles are pools in which population abundance was estimated and open circles are pools and non-pool wet reaches. Habitat Reach indicates the river kilometer and the number count of the habitat unit consecutively counting downstream to upstream. SC indicates a side channel off the main river channel.] 

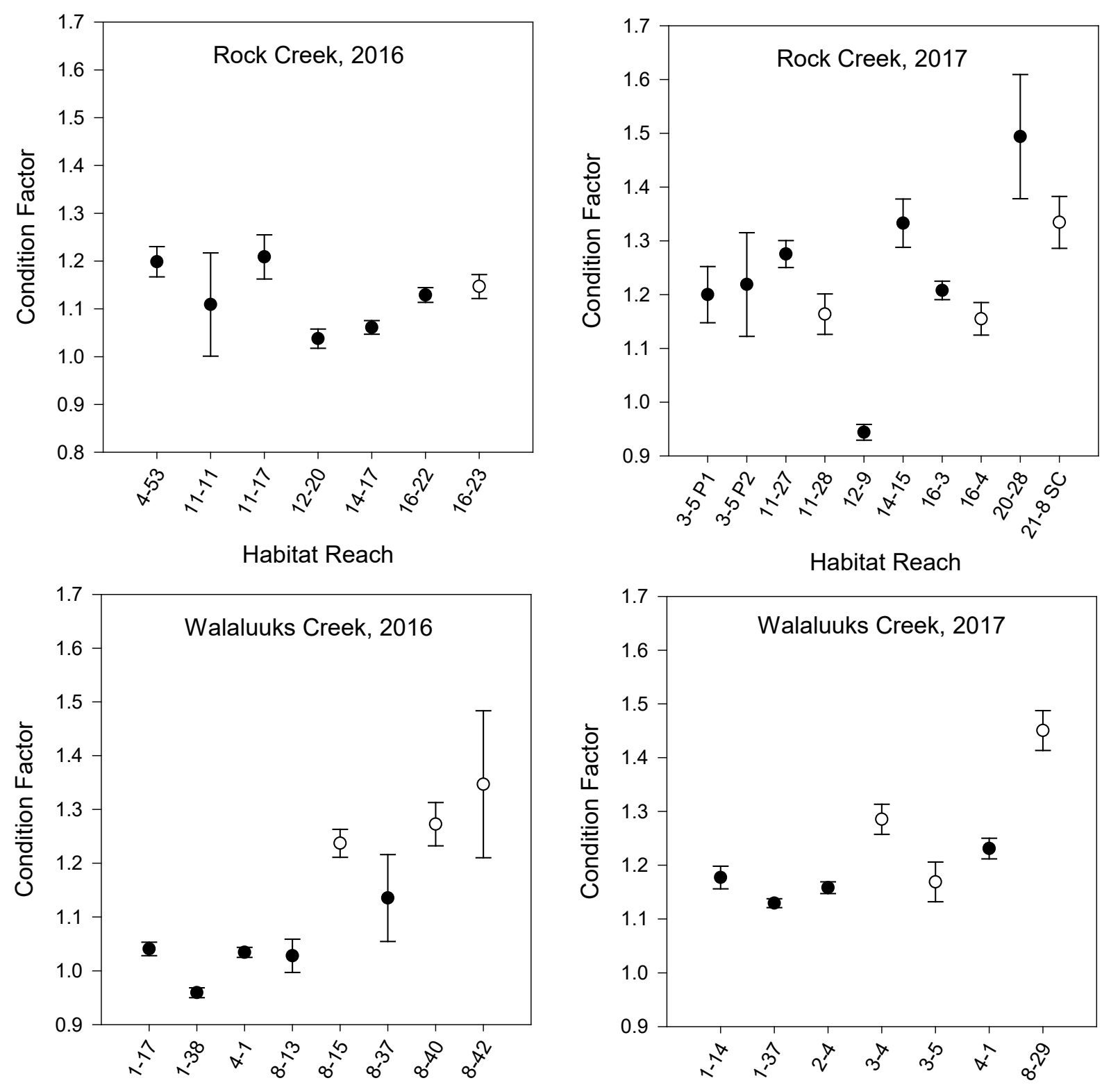

Habitat Reach

Habitat Reach

Figure 14. Graphs showing Fulton's condition factor and standard error for young of year Coho salmon (Oncorhynchus kisutch) captured by electrofishing in Rock Creek and Walaluuks Creek, Washington, during autumn 2016 and 2017. [Dark circles indicate pools in which population abundance was estimated and open circles are pools and non-pool wet reaches. Habitat Reach indicates the approximate river kilometer and the number count of the habitat unit consecutively counting downstream to upstream. SC indicates a side channel off the main river channel.] 


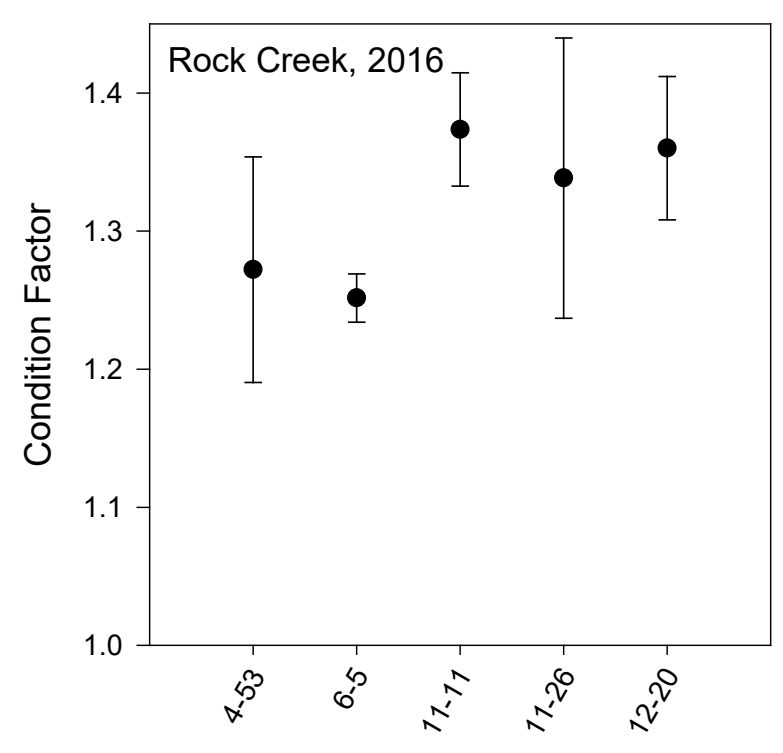

Habitat Reach

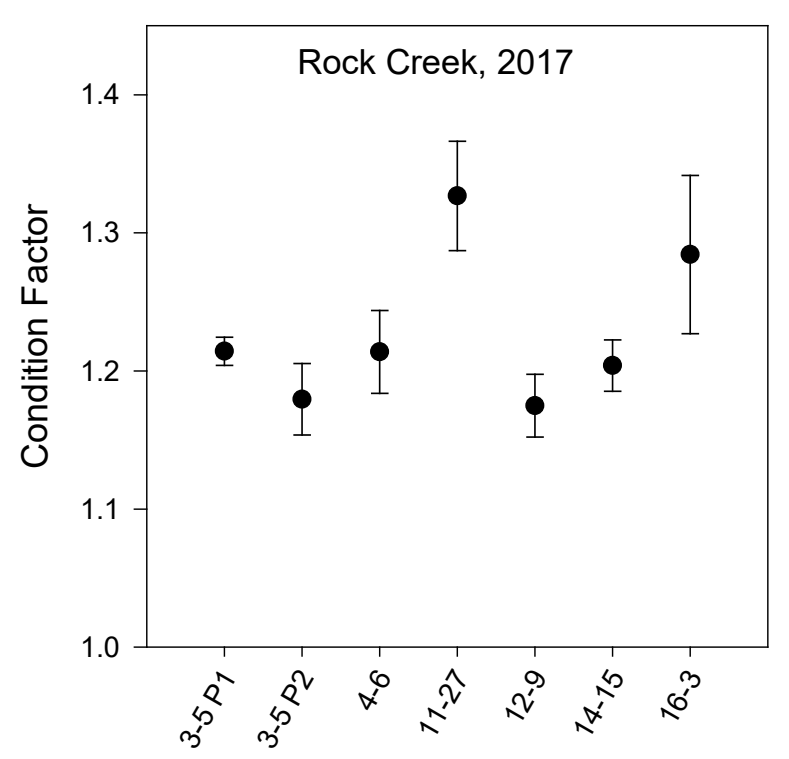

Habitat Reach

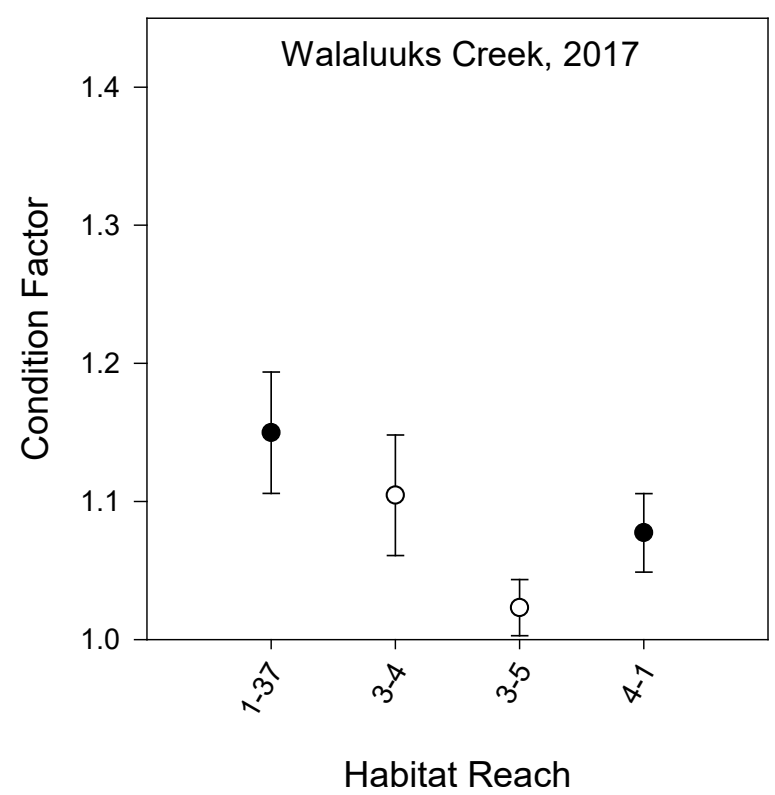

Figure 15. Graphs showing Fulton's condition factor and standard error for young of year (length less than 100 millimeters) bridgelip suckers (Catostomus columbianus) captured by electrofishing in Rock Creek and Walaluuks Creek, Washington, during autumn 2016 and 2017. [No bridgelip suckers were captured in Walaluuks Creek during 2016. Dark circles indicate pools in which population abundance was estimated and open circles are pools and non-pool wet reaches. Habitat Reach indicates the approximate river kilometer and the number count of the habitat unit consecutively counting downstream to upstream.] 


\section{Fish Movement, Travel Times, and Survival Estimates}

Juvenile $O$. mykiss and Coho salmon PIT tagged in the autumn typically migrated downstream in April and May (figs. 16 and 17). Some O. mykiss were observed delaying outmigration, spending an extra year in the Rock Creek subbasin before moving downstream in April and May of the next year (fig. 16). The majority of the fish movement downstream occurred on the descending arm of spring peak flow events (figs. 16 and 17). A small proportion of fish were observed moving downstream in winter months with detections at RCS (rkm 13) and RCL (rkm 5). These fish may have continued to rear in the system between sites or downstream of RCL. During winter months, juvenile bypass facilities on the Columbia River are not typically operating, so detection at these sites is not possible. Release location did not appear to alter out-migration timing for $O$. mykiss or Coho salmon tagged in Rock and Walaluuks Creeks (figs. 16 and 17).

During 2016, 65 bridgelip suckers were PIT-tagged of which 13 (20 percent) were later detected at a PTIS array. Bridgelip suckers were observed moving both upstream and downstream. During 2016, 49 bridgelip suckers were tagged and released downstream of RCL of which 2 were detected moving upstream at the RCL detection site (table 4). Very few bridgelip suckers $(n=16)$ were tagged upstream of RCL during 2016. Of these, five were detected moving downstream at RCL between November and March, and the other six were detected moving downstream during May 2017. During 2017, 243 bridgelip suckers were PIT-tagged, of which 60 (25 percent) were later detected at a PTIS. The majority $(\mathrm{n}=141)$ of the bridgelip suckers were tagged and released downstream of RCL and were not detected thereafter (table 4). Another 48 were tagged and released downstream of RCS in pools near rkm 11 and 12 of which 4 were detected moving upstream in November past RCS and then later downstream in May and 22 were detected moving downstream in May. The remaining bridgelip suckers tagged in 2017 were released upstream of RCS in Rock Creek $(\mathrm{n}=35)$ and in Walaluuks Creek $(\mathrm{n}=19)$. For the fish released in Rock Creek pools near rkm 14 and 16, nine were detected moving downstream from November to March, of which four were later detected at RCL in May. An additional 13 fish were detected moving downstream at RCL in May. The majority of fish released in Walaluuks Creek, were detected moving downstream in April and May, with the exception of two fish that were detected at RCS in November and January, and which were also detected at RCL in May. Tracking fish movement during the summer months is not possible as the stream becomes disconnected and the PTIS arrays are deactivated until flows begin to return in OctoberNovember. Additionally, an occasional power outage or equipment failure disrupted the continuous operation of the PTIS arrays (see appendix 3 for activity log). 

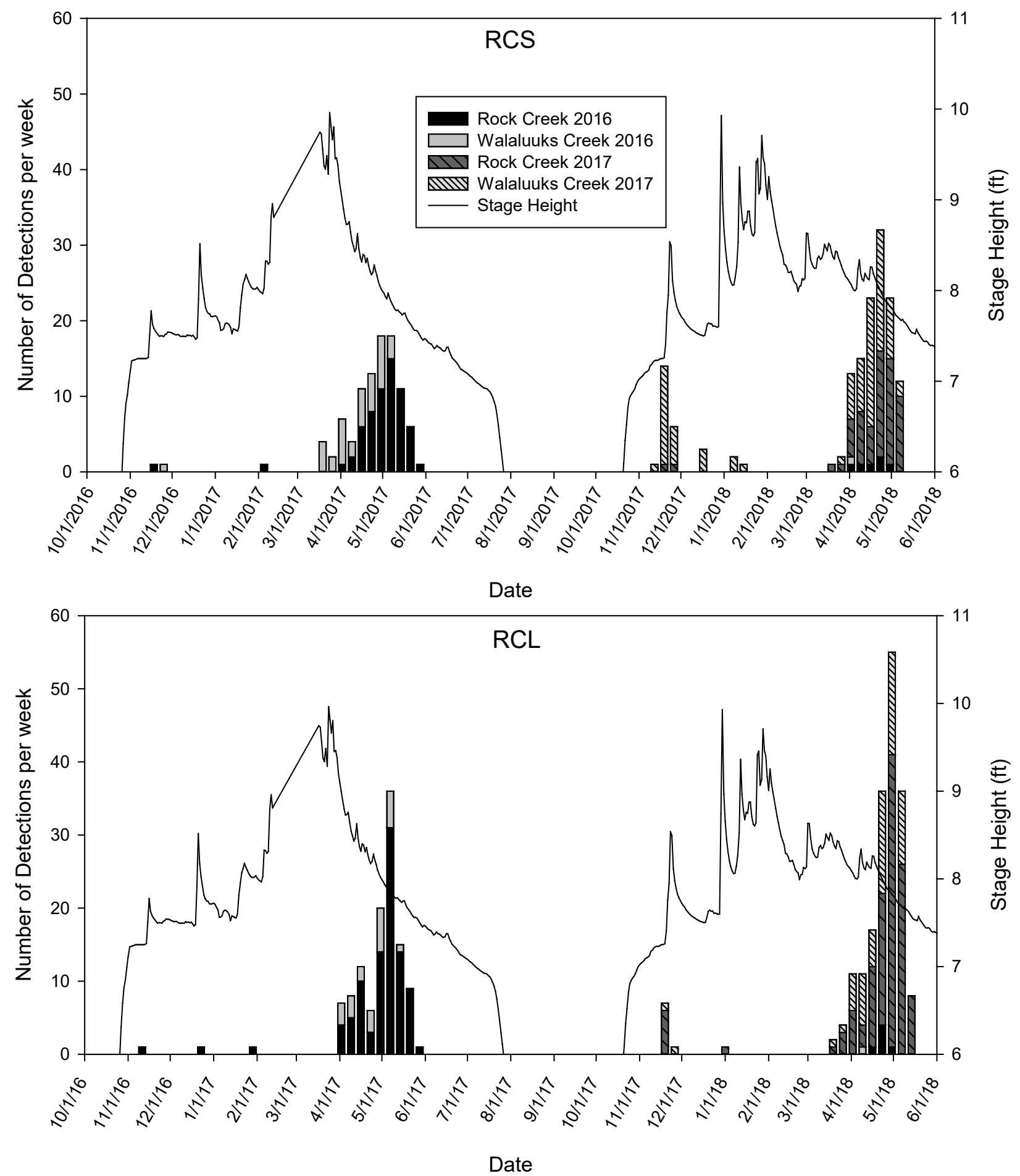

Figure 16. Graphs showing distribution of first detections of passive-integrated-transponder (PIT) tagged Oncorhynchus mykiss at PIT tag information system detection arrays Rock Creek Squaw (RCS) (river kilometer [rkm] 13) and Rock Creek Longhouse (RCL) (rkm 5) by date and Rock Creek discharge (stage height) at rkm 12.9, 2016-18. [Bars indicate the year fish were tagged and release location either being in Rock or Walaluuks Creek, Washington.] 

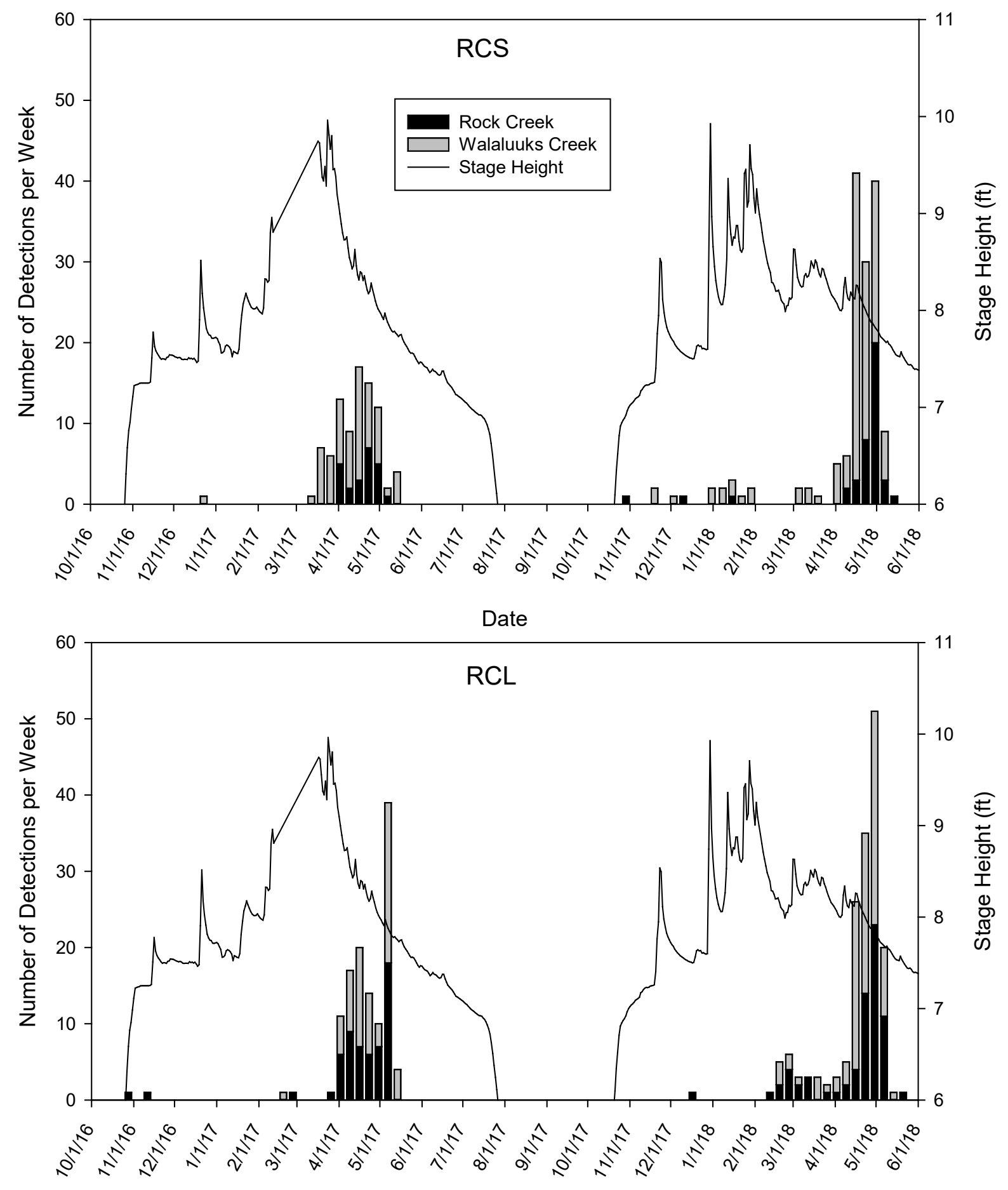

Date

Figure 17. Graphs showing distribution of first detections of passive-integrated-transponder (PIT) tagged Coho salmon (Oncorhynchus kisutch) at PIT tag information system detection arrays Rock Creek Squaw (RCS; river kilometer [rkm] 13) and Rock Creek Longhouse (RCL; rkm 5) by date and Rock Creek discharge (Stage Height) at rkm 12.9, Rock or Walaluuks Creek, Washington, 2016-18. [Bars indicate the year fish were tagged and whether the release location was in Rock or Walaluuks Creek, Washington.] 
Median travel times (days) and rates (days/rkm) were similar between release years for out-migrating $O$. mykiss when release sites (both Walaluuks and Rock Creek) were combined. The overall median travel rate between RCS to RCL was 0.12 days per river kilometer $(\mathrm{d} / \mathrm{rkm})$ for 2016 and $0.13 \mathrm{~d} / \mathrm{rkm}$ for 2017 and median travel time was about 1 day for both years (table 5). The range for travel time was 0.12 to 168.93 days from RCS to RCL, suggesting that some fish are likely rearing in lower Rock Creek during winter months. The $75^{\text {th }}$ percentile for travel time between RCS and RCL was 2.58 days for 2016 and 7.53 days for 2017, indicating once the majority of the fish start moving downstream they do not spend many days rearing in the lower river. The median travel rate for out-migrating O. mykiss from RCL to John Day Dam juvenile bypass (JDJ) was $0.15 \mathrm{~d} / \mathrm{rkm}$ and $0.18 \mathrm{~d} / \mathrm{rkm}$, for 2016 and 2017, with a median travel time of 3.91 and 4.68 days for 2016 and 2017. The overall travel time for O. mykiss from RCL to JDJ ranged from 0.88 to 151.34 days, with mean travel times of 6.04 and 11.33 days for 2016 and 2017. Differences for travel rates and times between years were noted for $O$. mykiss tagged and released in Walaluuks Creek with the 2017 median travel rate being over two times slower than the previous year from RCS to RCL (table 5). This was also a slower rate than for Rock Creek released O. mykiss. During 2017, the number of O. mykiss tagged and contacted out-migrating downstream more than doubled within Walaluuks Creek. The median travel rates of Walaluuks Creek released $O$. mykiss were similar across years for RCL to JDJ but, were slower than Rock Creek released fish. However, the number of $O$. mykiss contacted at both RCL and JDJ was much lower $(\mathrm{n}=4)$ for 2016 than $2017(\mathrm{n}=16)$ and was less than half the number of fish from Rock Creek releases ( $\mathrm{n}=60$; table 5). 
Table 5. Summary statistics for travel time (days) and travel rate (days per river kilometer [rkm]) for steelhead (Oncorhynchus mykiss) first detections between passive-integrated-transponder tag interrogation arrays Rock Creek Squaw (rkm 13) and Rock Creek Longhouse (rkm 5) and Rock Creek Longhouse and John Day Dam Juvenile Bypass (Columbia River; rkm 347), Washington.

[Abbreviations: d, days; JDJ, John Day Dam Juvenile Bypass; n, number of fish; rkm, river kilometer; RCS, Rock Creek Squaw; RCL, Rock Creek Longhouse; Pct, percentile]

\begin{tabular}{|c|c|c|c|c|c|c|}
\hline & \multicolumn{6}{|c|}{ Reach, release site, and tag year } \\
\hline & \multicolumn{6}{|c|}{ RCS to RCL (8 rkm) } \\
\hline & \multicolumn{2}{|c|}{ Rock Creek } & \multicolumn{2}{|c|}{ Walaluuks Creek } & \multicolumn{2}{|c|}{ Combined } \\
\hline & 2016 & 2017 & 2016 & 2017 & 2016 & 2017 \\
\hline $\mathrm{n}$ & 63 & 80 & 22 & 50 & 85 & 130 \\
\hline $\begin{array}{l}\text { Median rate } \\
(\mathrm{d} / \mathrm{rkm})\end{array}$ & 0.12 & 0.13 & 0.10 & 0.22 & 0.12 & 0.13 \\
\hline Median (d) & 0.92 & 1.01 & 0.82 & 1.77 & 0.92 & 1.05 \\
\hline $\begin{array}{l}25-75 \text { th Pct } \\
\text { (d) }\end{array}$ & $0.24-1.95$ & $0.33-2.97$ & $0.15-7.93$ & $0.37-10.09$ & $0.22-2.58$ & $0.34-7.53$ \\
\hline $\begin{array}{l}\text { 10-90th Pct } \\
\text { (d) }\end{array}$ & $0.15-10.49$ & $0.22-146.80$ & $0.13-17.68$ & $0.17-123.02$ & $0.14-11.79$ & $0.21-139.41$ \\
\hline \multirow[t]{2}{*}{ Range (d) } & $0.13-148.78$ & $0.13-165.43$ & $0.12-161.38$ & $0.12-168.93$ & $0.12-161.38$ & $0.12-168.93$ \\
\hline & \multicolumn{6}{|c|}{ RCL to JDJ (26 rkm) } \\
\hline $\mathrm{n}$ & 25 & 35 & 4 & 16 & 29 & 51 \\
\hline $\begin{array}{l}\text { Median rate } \\
(\mathrm{d} / \mathrm{rkm})\end{array}$ & 0.15 & 0.15 & 0.23 & 0.24 & 0.15 & 0.18 \\
\hline Median (d) & 3.80 & 3.87 & 6.03 & 6.30 & 3.91 & 4.68 \\
\hline $\begin{array}{l}25-75 \text { th Pct } \\
\text { (d) }\end{array}$ & $2.39-5.67$ & $2.91-12.71$ & $5.04-7.86$ & $3.98-9.11$ & $2.89-6.39$ & $2.98-11.54$ \\
\hline $\begin{array}{l}10-90^{\text {th }} \mathrm{Pct} \\
\text { (d) }\end{array}$ & $1.78-12.10$ & $2.12-27.71$ & $3.91-10.50$ & $3.41-14.64$ & $1.91-12.32$ & $2.33-25.58$ \\
\hline Range (d) & $0.88-22.50$ & $1.71-151.34$ & $3.15-12.26$ & $2.25-18.61$ & $0.88-22.50$ & $1.71-151.34$ \\
\hline
\end{tabular}

Coho salmon smolts travel times and rates were more variable across release sites and years and were generally slower than $O$. mykiss smolts. The overall median travel rate between RCS to RCL was $0.38(\mathrm{~d} / \mathrm{rkm})$ and $0.24(\mathrm{~d} / \mathrm{rkm})$ for 2016 and 2017, and the median travel time was 3.02 and 1.91 days for 2016 and 2017 (table 6). The median travel times and rates were two to three times slower than that of the $O$. mykiss smolts out-migrating during the same years. The range of travel time was 0.10 to 117.01 days for 2016 and 2017 combined, indicating it was likely that some Coho salmon smolts were spending time rearing during winter months in the lower river section. Travel times between RCS and RCL were slower for fish released in Walaluuks Creek than for those released in Rock Creek (table 6). This could be a result of many of the Coho salmon tagged within Walaluuks Creek were within the first two river kilometers, which is near the RCS site, indicating some of these fish move into Rock Creek downstream of RCS to spend time rearing. The median travel times and rates for Coho salmon smolts outmigrating from RCL to JDJ were 12.79 and 6.02 days and 0.49 and $0.23 \mathrm{~d} / \mathrm{rkm}$ for 2016 and 2017 (table 6). This was also slower than that of the O. mykiss smolts out-migrating during the same years (tables 5 and 6). Travel time from RCL to JDJ ranged from 1.91 to 46.13 days, with mean travel times of 13.84 and 10.81 days for 2016 and 2017 for Coho salmon smolts. The median travel rates for Coho salmon were similar across release locations and years for the RCL to JDJ reach, except for fish released in Rock Creek 2016. The median travel rate was two to three times slower for Coho salmon tagged and released in Rock Creek 2016 compared to other years and Walaluuks Creek releases (table 6). 
Table 6. Summary statistics for travel time (days) and travel rate (days per river kilometer [rkm]) for Coho salmon (Oncorhynchus kisutch) smolts first detections between passive-integrated-transponder tag interrogation arrays Rock Creek Squaw (rkm 13) and Rock Creek Longhouse (rkm 5) and Rock Creek Longhouse and John Day Dam Juvenile Bypass (Columbia River, rkm 347), Washington.

[Abbreviations: d, days; n, number of fish; JDJ, John Day Dam Juvenile Bypass; Pct, percentile; rkm, river kilometer; RCS, Rock Creek Squaw; RCL, Rock Creek Longhouse]

\begin{tabular}{|c|c|c|c|c|c|c|}
\hline & \multicolumn{6}{|c|}{ Reach, release site, and tag year } \\
\hline & \multirow{2}{*}{\multicolumn{2}{|c|}{ Rock Creek }} & RCS to & (8 rkm) & & \\
\hline & & & \multicolumn{2}{|c|}{ Walaluuks Creek } & \multicolumn{2}{|c|}{ Combined } \\
\hline & 2016 & 2017 & 2016 & 2017 & 2016 & 2017 \\
\hline $\mathrm{n}$ & 20 & 32 & 45 & 83 & 65 & 115 \\
\hline $\begin{array}{l}\text { Median rate } \\
(\mathrm{d} / \mathrm{rkm})\end{array}$ & 0.23 & 0.19 & 0.41 & 0.26 & 0.38 & 0.24 \\
\hline Median (d) & 1.87 & 1.51 & 3.29 & 2.11 & 3.02 & 1.91 \\
\hline $\begin{array}{l}25-75 \text { th Pct } \\
\text { (d) }\end{array}$ & $0.92-8.59$ & $1.10-2.65$ & $0.94-15.70$ & $1.00-4.91$ & $0.94-13.00$ & $1.04-4.18$ \\
\hline $\begin{array}{l}10-90^{\text {th }} \text { Pct } \\
\text { (d) }\end{array}$ & $0.27-19.31$ & $0.93-6.70$ & $0.19-31.34$ & $0.29-14.50$ & $0.19-25.89$ & $0.48-12.88$ \\
\hline \multirow[t]{2}{*}{ Range (d) } & $0.16-22.33$ & $0.67-40.56$ & $0.10-49.07$ & $0.15-117.01$ & $0.10-49.07$ & $0.15-117.01$ \\
\hline & \multicolumn{6}{|c|}{ RCL to JDJ (26 rkm) } \\
\hline $\mathrm{n}$ & 14 & 10 & 10 & 11 & 24 & 21 \\
\hline $\begin{array}{l}\text { Median rate } \\
(\mathrm{d} / \mathrm{rkm})\end{array}$ & 0.64 & 0.21 & 0.30 & 0.32 & 0.49 & 0.23 \\
\hline $\operatorname{Median}(\mathrm{d})$ & 16.75 & 5.49 & 7.69 & 8.31 & 12.79 & 6.02 \\
\hline $\begin{array}{l}25-75 \text { th Pct } \\
\text { (d) }\end{array}$ & $7.22-22.83$ & $2.69-9.77$ & $6.45-18.31$ & $4.07-12.49$ & $6.15-22.46$ & $3.34-11.26$ \\
\hline $\begin{array}{l}\text { 10-90th Pct } \\
\text { (d) }\end{array}$ & $2.90-24.71$ & $2.29-31.31$ & $2.90-24.71$ & $3.34-17.98$ & $2.97-23.88$ & $2.34-29.66$ \\
\hline Range & $1.91-28.92$ & $1.96-46.13$ & $2.97-23.47$ & $2.34-33.83$ & $1.91-28.92$ & $1.96-46.13$ \\
\hline
\end{tabular}

The best-fit survival model for $O$. mykiss, released upstream of rkm 13, was an interaction model including reach, release group, and release year with detection probability varying by reach (table 7). For $O$. mykiss released between rkm 5 and 13, the best-fit survival model was an additive model including reach and release year, with detection probability varying by reach (table 8 ). The RCS survival reach is the first downstream detection site within the Rock Creek system and includes overwinter survival. For fish released downstream of RCS, RCL is the first detection site and includes overwinter survival as well. O. mykiss survival estimates for the RCS reach were similar across years and release groups, ranging from 0.358 to 0.391 (table 9 and fig. 18). For $O$. mykiss released upstream of RCS and migrating through RCL reach, survival estimates ranged from 0.673 to 1 for the RCL reach. For $O$. mykiss, tagged and released downstream of RCS and overwintered within the RCL reach, survival estimates were significantly different across years (fig. 18). Survival was lower for fish tagged and released during 2016 at 0.212 compared to 0.547 for $O$. mykiss tagged and released during 2017. Survival estimates for the JDA reach were variable and confidence intervals were large due to the smaller number of fish being detected at John Day Dam and downstream at Columbia River detection sites (fig. 18 and table 3). Survival estimates for JDA reach ranged from 0.411 to 0.895 .

For Coho salmon, released upstream of rkm 13, the best-fit survival model was an additive model with reach, release group, and release year with a probability detection interaction model with reach and release year (table 7). For Coho salmon released between rkm 5 and 13, the best-fit survival model was an additive model including reach and release year, with detection probability varying by reach (table 8). Survival estimates for RCS reach were lower by 
release group for $2016(0.347-0.474)$ than for 2017 (0.536-0.662) released fish, with Walaluuks release group lower than upper Rock Creek release groups (table 10 and fig. 19). For Coho salmon, released upstream of RCS and migrating through RCL reach, survival estimates were similar across release years and groups ranging from 0.902 to 0.972 for the RCL reach. For Coho salmon tagged and released downstream of RCS and overwintered within the RCL reach, survival estimates had a consistent pattern with 2016 released fish (0.213), which was lower than fish released during 2017 (0.402). Survival estimates for the JDA reach varied with large confidence intervals due to the smaller number of fish being detected at JDA and downstream at Columbia River detection sites and ranged from 0.528 to 1 (fig. 19).

Table 7. Models of survival probability for reach survival analysis of juvenile Oncorhynchus mykiss and Coho salmon (O. kisutch) released in Walaluuks and Rock Creeks (release group) upstream of the confluence with Walaluuks Creek during autumn of 2016 and 2017 (release year), Washington.

[Survival reaches were from release sites to next downstream locations of detection and between. This included the two Rock Creek sites and rkm 13 and rkm 5 and mainstem Columbia River sites at John Day Dam juvenile bypass, rkm 347 and any other site downstream to the estuary. Model: phi, survival probability; Rel, release; p, detection probability. K: Number of parameters. AIC $_{C}$ : Akaike's Information Criterion. Delta AICC: Difference from model with smallest $\left.\mathrm{AIC}_{\mathrm{C}}\right]$

\begin{tabular}{|c|c|c|c|c|c|}
\hline Model & $\mathrm{K}$ & Deviance & $\mathrm{AIC}_{\mathrm{c}}$ & $\begin{array}{l}\text { Delta } \\
\text { AlC } \\
\end{array}$ & $\begin{array}{c}\text { AIC } \\
\text { Weight }\end{array}$ \\
\hline \multicolumn{6}{|c|}{ O. mykiss } \\
\hline phi (Reach*Rel group*Rel year) p (Reach) & 16 & 33.8 & 2426.4 & 0.0 & 0.947 \\
\hline phi (Reach + Rel group) p (Reach) & 8 & 57.9 & 2434.3 & 7.8 & 0.019 \\
\hline phi (Reach + Rel group + Rel year) p (Reach) & 9 & 56.2 & 2434.6 & 8.2 & 0.016 \\
\hline phi (Reach + Rel year) p (Reach) & 8 & 59.2 & 2435.9 & 9.2 & 0.009 \\
\hline phi (Reach) p (Reach) & 7 & 61.5 & 2435.9 & 9.5 & 0.008 \\
\hline \multicolumn{6}{|c|}{ Coho salmon } \\
\hline phi (Reach + Rel group + Rel year) p (Reach*Rel year) & 13 & 73.1 & 2041.0 & 0.0 & 0.506 \\
\hline phi (Reach*Rel group*Rel year) p (Reach*Rel year) & 20 & 62.2 & 2044.5 & 3.5 & 0.477 \\
\hline phi (Reach + Rel year) p (Reach*Rel group) & 12 & 82.3 & 2048.2 & 7.2 & 0.164 \\
\hline phi (Reach + Rel group) p (Reach*Rel group) & 12 & 95.2 & 2061.0 & 20.1 & 0.000 \\
\hline phi (Reach) p (Reach*Rel group) & 11 & 104.9 & 2068.7 & 27.8 & 0.000 \\
\hline
\end{tabular}

Table 8. Models of survival probability for reach survival analysis of juvenile Oncorhynchus mykiss and Coho salmon (0. kisutch) released in Rock Creek between rkm 5 and rkm 13 during autumn of 2016 and 2017 (release year), Washington.

[Survival reaches were from release sites to next downstream locations of detection and between. This included the Rock Creek site at rkm 5 and mainstem Columbia River sites at John Day Dam juvenile bypass, rkm 347 and any other site downstream to the estuary. Model: phi, survival probability; Rel, release; p, detection probability. K: Number of parameters. AIC $\mathbf{C}_{\mathrm{C}}$ : Akaike's Information Criterion. Delta $\mathbf{A I C}_{\mathrm{C}}$ : Difference from model with smallest $\underline{\left.\mathrm{AIC}_{\mathrm{C}}\right]}$

\begin{tabular}{|c|c|c|c|c|c|}
\hline Model & $\mathrm{K}$ & Deviance & $\mathrm{AlC}_{\mathrm{c}}$ & $\begin{array}{l}\text { Delta } \\
\text { AlC }_{c}\end{array}$ & $\begin{array}{c}\text { AIC } \\
\text { Weight }\end{array}$ \\
\hline \multicolumn{6}{|c|}{ O. mykiss } \\
\hline phi (Reach + Rel year) p (Reach) & 6 & 7.9 & 330.2 & 0.0 & 0.649 \\
\hline phi (Reach*Rel year) p (Reach) & 7 & 7.0 & 331.4 & 1.2 & 0.350 \\
\hline phi (Reach) p (Reach) & 5 & 27.9 & 348.0 & 17.5 & 0.000 \\
\hline \multicolumn{6}{|c|}{ Coho salmon } \\
\hline phi (Reach + Rel year) p (Reach) & 6 & 7.0 & 227.7 & 0.0 & 0.449 \\
\hline phi (Reach*Rel year) p (Reach) & 7 & 5.4 & 228.5 & 0.8 & 0.328 \\
\hline phi (Reach) p (Reach & 5 & 10.5 & 228.8 & 1.1 & 0.223 \\
\hline
\end{tabular}


Table 9. Survival modeling results by release group, release year, and reach for juvenile Oncorhynchus mykiss released upstream of river kilometer 13 in Rock Creek, in Walaluuks Creek, and in Rock Creek between rkm 5 and 13 (release group RLO) for releases made during autumn of 2016 and 2017, Washington.

[Reach: RCS, from release location to the PIT-tag Interrogation Array RCS at rkm 13; RCL from rkm 13 to 5 RCL PIT-tag Interrogation Array; and JDA, from RCL to John Day Dam on the Columbia River, rkm 347.

Abbreviations: CI, confidence interval; JDA, John Day reach; rkm, river kilometer; PIT, passive integrated transponder; RCL, Rock Creek Longhouse reach; RCS, Rock Creek Squaw reach; RLO, Rock Creek lower release group; RUP, Rock Creek upper release group; WLC, Walaluuks Creek release group; \%, percent]

\begin{tabular}{llllccc}
$\begin{array}{c}\text { Release group } \\
\text { Year }\end{array}$ & Reach & $\begin{array}{c}\text { Survival } \\
\text { estimate }\end{array}$ & $\begin{array}{c}\text { Standard } \\
\text { error }\end{array}$ & $\begin{array}{c}\text { Lower 95\% } \\
\text { Cl }\end{array}$ & $\begin{array}{c}\text { Upper 95\% } \\
\text { Cl }\end{array}$ & $\begin{array}{c}\text { Detection } \\
\text { probability }\end{array}$ \\
\hline RUP 2016 & RCS & 0.391 & 0.033 & 0.329 & 0.458 & 0.813 \\
RUP 2016 & RCL & 1.000 & 0 & 1.000 & 1.000 & 0.880 \\
RUP 2016 & JDA & 0.845 & 0.232 & 0.145 & 0.994 & 0.313 \\
WLC 2016 & RCS & 0.366 & 0.049 & 0.277 & 0.466 & 0.813 \\
WLC 2016 & RCL & 0.673 & 0.092 & 0.476 & 0.824 & 0.880 \\
WLC 2016 & JDA & 0.535 & 0.232 & 0.156 & 0.877 & 0.313 \\
RUP 2017 & RCS & 0.360 & 0.027 & 0.309 & 0.414 & 0.813 \\
RUP 2017 & RCL & 0.833 & 0.049 & 0.716 & 0.908 & 0.880 \\
RUP 2017 & JDA & 0.776 & 0.213 & 0.239 & 0.974 & 0.313 \\
WLC 2017 & RCS & 0.358 & 0.031 & 0.300 & 0.420 & 0.813 \\
WLC 2017 & RCL & 0.729 & 0.058 & 0.603 & 0.827 & 0.880 \\
WLC 2017 & JDA & 0.895 & 0.252 & 0.0433 & 0.999 & 0.313 \\
RLO 2016 & RCL & 0.212 & 0.047 & 0.134 & 0.318 & 0.790 \\
RLO 2016 & JDA & 0.411 & 0.225 & 0.102 & 0.811 & 0.428 \\
RLO 2017 & RCL & 0.547 & 0.077 & 0.397 & 0.689 & 0.790 \\
RLO 2017 & JDA & 0.758 & 0.179 & 0.317 & 0.955 & 0.428 \\
\hline
\end{tabular}

Table 10. Survival modeling results by release group, release year, and reach for juvenile Coho salmon (Oncorhynchus kisutch) released upstream of rkm 13 in Rock Creek, in Walaluuks Creek, and in Rock Creek between rkm 5 and 13 (release group RLO) for releases made during autumn of 2016 and 2017, Washington.

[Reach: RCS, from release location to the PIT-tag Interrogation Array RCS at rkm 13; RCL from rkm 13 to rkm 5 RCL PIT-tag Interrogation Array; and JDA, from RCL to John Day Dam on the Columbia River, rkm 347.

Abbreviations: CI, confidence interval; JDA, John Day reach; rkm, river kilometer; PIT, passive integrated transponder; RCL, Rock Creek Longhouse reach; RCS, Rock Creek Squaw reach; RLO, Rock Creek lower release group; RUP, Rock Creek upper release group; WLC, Walaluuks Creek release group; \%, percent]

\begin{tabular}{lllcccc}
\hline $\begin{array}{c}\text { Release group } \\
\text { year }\end{array}$ & Reach & $\begin{array}{c}\text { Survival } \\
\text { estimate }\end{array}$ & $\begin{array}{c}\text { Standard } \\
\text { error }\end{array}$ & $\begin{array}{c}\text { Lower 95\% } \\
\text { Cl }\end{array}$ & Upper 95\% Cl & $\begin{array}{c}\text { Detection } \\
\text { Probability }\end{array}$ \\
\hline RUP 2016 & RCS & 0.474 & 0.044 & 0.390 & 0.560 & 0.592 \\
RUP 2016 & RCL & 0.940 & 0.044 & 0.775 & 0.986 & 0.809 \\
RUP 2016 & JDA & 0.741 & 0.210 & 0.251 & 0.961 & 0.278 \\
WLC 2016 & RCS & 0.347 & 0.029 & 0.293 & 0.405 & 0.592 \\
WLC 2016 & RCL & 0.902 & 0.069 & 0.663 & 0.977 & 0.809 \\
WLC 2016 & JDA & 0.628 & 0.246 & 0.177 & 0.930 & 0.278 \\
RUP 2017 & RCS & 0.662 & 0.040 & 0.580 & 0.736 & 0.813 \\
RUP 2017 & RCL & 0.972 & 0.023 & 0.874 & 0.994 & 0.793 \\
RUP 2017 & JDA & 0.862 & 0.131 & 0.421 & 0.982 & 0.156 \\
WLC 2017 & RCS & 0.536 & 0.032 & 0.473 & 0.597 & 0.813 \\
WLC 2017 & RCL & 0.953 & 0.037 & 0.799 & 0.990 & 0.793 \\
WLC 2017 & JDA & 0.786 & 0.177 & 0.319 & 0.967 & 0.156 \\
RLO 2016 & RCL & 0.213 & 0.066 & 0.111 & 0.371 & 0.822 \\
RLO 2016 & JDA & 1.000 & 0 & 1.000 & 1.000 & 0.377 \\
RLO 2017 & RCL & 0.402 & 0.076 & 0.265 & 0.555 & 0.822 \\
\hline
\end{tabular}




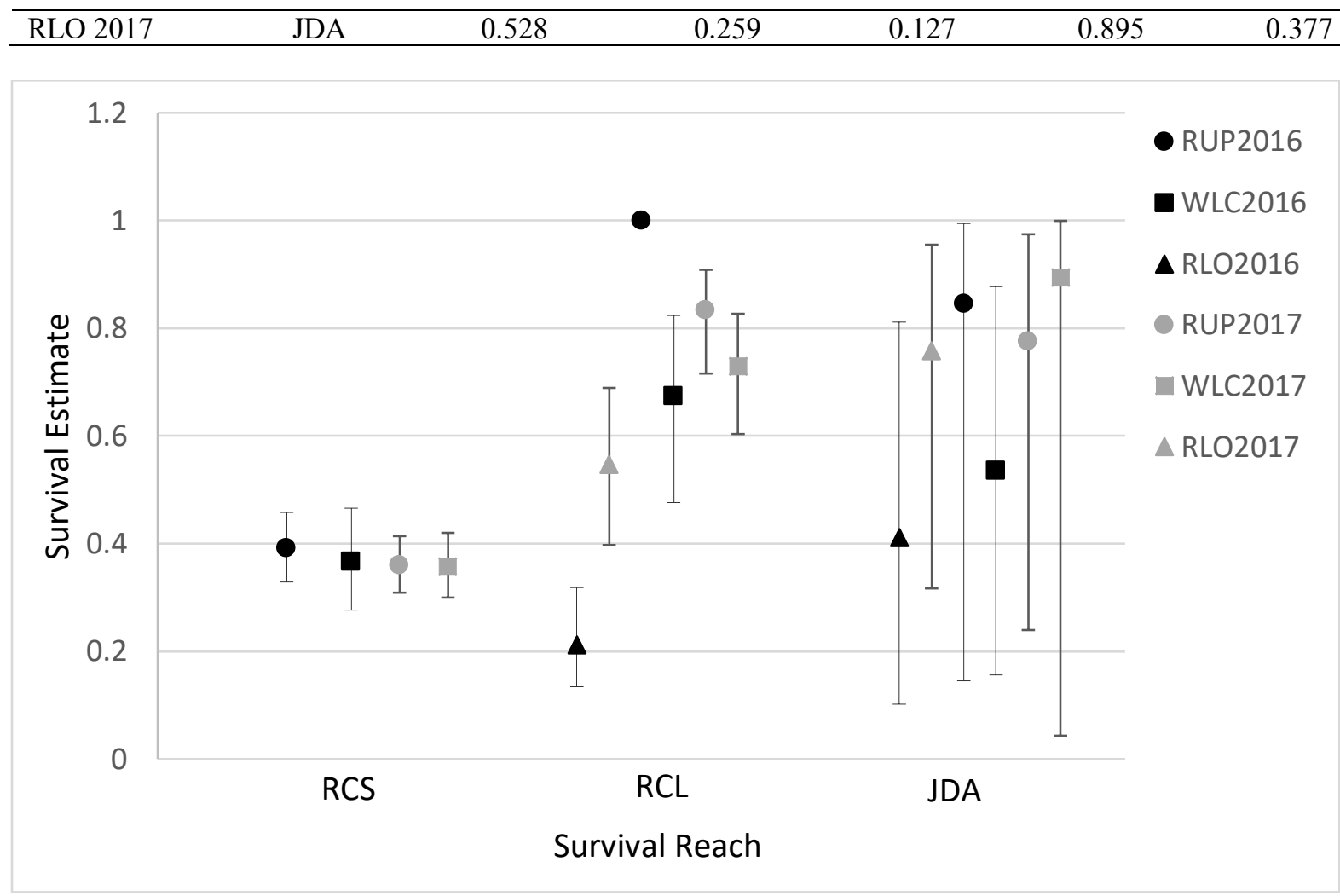

Figure 18. Graph showing steelhead (Oncorhynchus mykiss) survival estimates with 95 percent confidence intervals for fish tagged with passive integrated transponders (PIT) and released during 2016 and 2017 in Walaluuks and Rock Creek, Washington and migrating downstream. [Survival reaches include: RCS, from release location to the PIT-tag Interrogation Array RCS at rkm 13; RCL from rkm 13 to rkm 5 RCL PIT-tag Interrogation Array; and JDA, from RCL to John Day Dam on the Columbia River, rkm 347. Release groups include the year of release (2016 or 2017) and the location: RUP fish released in Rock Creek upstream of rkm 13; WLC fish released in Walaluuks Creek; RLO fish released in Rock Creek between rkm 13 and 5 .] 


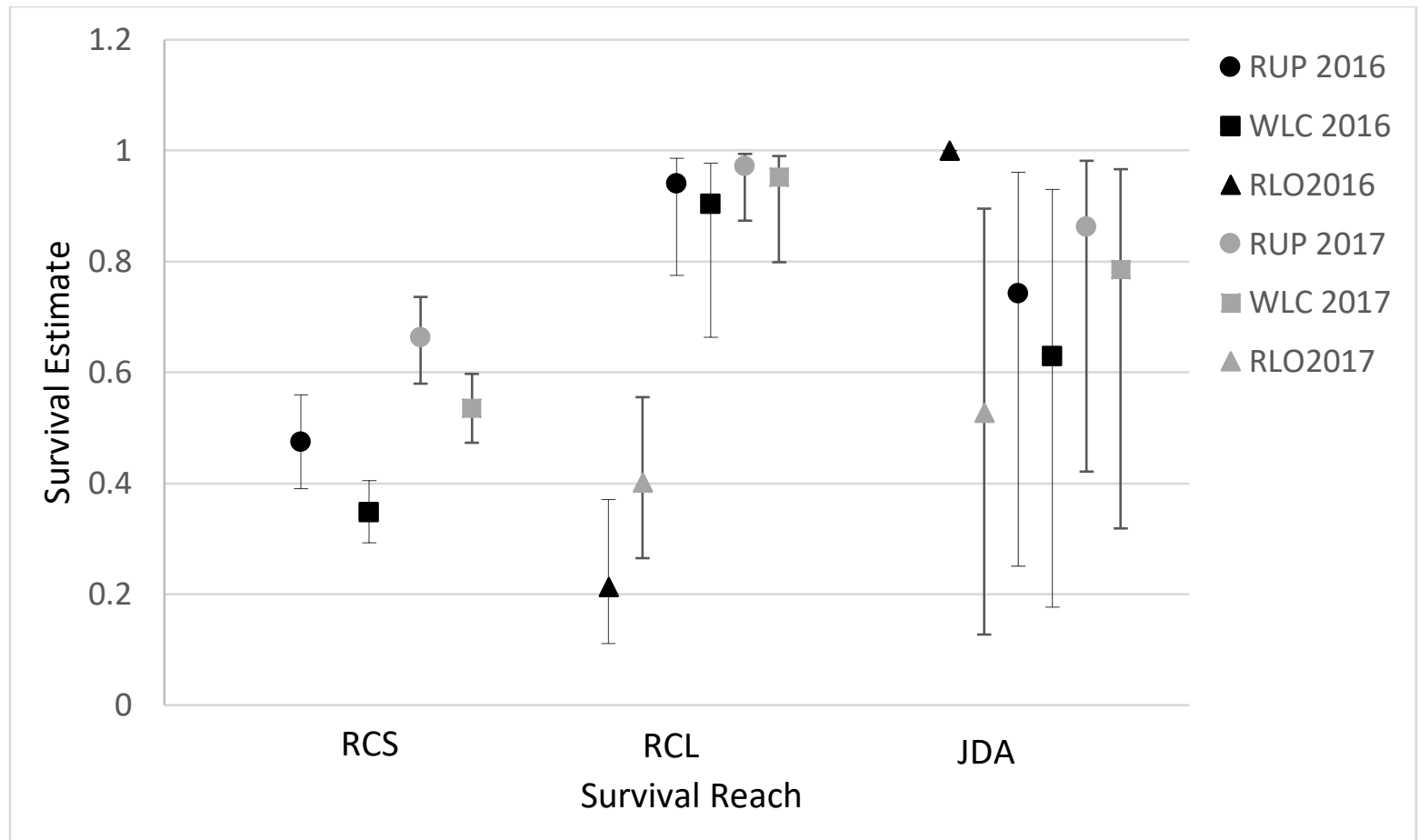

Figure 19. Graph showing Coho salmon (Oncorhynchus kisutch) survival estimates with 95 percent confidence intervals for fish tagged with passive integrated transponders (PIT) and released during 2016 and 2017 in Walaluuks and Rock Creeks, Washington, and migrating downstream. [Survival reaches include: RCS, from release location to the PIT-tag Interrogation Array RCS at rkm 13; RCL from rkm 13 to rkm 5 RCL PIT-tag Interrogation Array; and JDA, from RCL to John Day Dam on the Columbia River, rkm 347. Release groups include the year of release (2016 or 2017) and the location: RUP fish released in Rock Creek upstream of rkm 13; WLC fish released in Walaluuks Creek; RLO fish released in Rock Creek between rkm 13 and 5.] 


\section{Out-of-Basin Fish Detections}

Detections of out-of-basin PIT tagged fish are continuing to be monitored at both the RCS and RCL PTIS sites for fish that were PIT tagged outside of Rock Creek subbasin but are detected within the subbasin. A detailed description of the 82 out-of-basin fish detections from 2009 to April 2016 was included in Harvey (2015). Since May 2016 to March 2019, eight out-ofbasin salmonids have been detected in Rock Creek. Of these, five were tagged as juveniles including: two wild summer steelhead (from Meacham Creek, Umatilla River, and Thirty Mile Creek, John Day River), two hatchery summer steelhead (from Omak Creek, Okanogan River, and Tucannon River), and one Coho salmon (from Prosser Hatchery). The wild steelhead from Meacham Creek on the Umatilla River out-migrated and returned 2 years later (2-salt) being detected as far upstream as Lower Granite Dam Adult Fish ladder in March with last detections occurring later in Rock Creek on April 26. This fish displayed a large range of straying behavior from what was presumably it's natal stream. The wild steelhead from John Day River basin was released in June and was detected at the John Day Adult fish ladder in December with a last detection at RCL in January. The hatchery summer steelhead from Omak Creek was released in April and was last detected at RCS and then RCL in May (as a juvenile), no other detections indicating successful migration to the ocean. The hatchery summer steelhead from Tucannon River, spent 1 year in the ocean (1-salt), was detected in Rock Creek in April, with the final detection downstream at John Day Dam in May. This fish displays potential kelt life history behavior. The Coho salmon appeared to out-migrate to the ocean for 1 year before migrating to Rock Creek in January. The remaining three out-of-basin steelhead detected in Rock Creek were tagged as adults, two were from Lower Granite Dam Adult Fish Ladder and one from Bonneville Dam Adult Fish Facility. The adults from Lower Granite Dam were tagged and released in October and were detected downstream the following March in Rock Creek. The adult from Bonneville Dam was tagged and released in July and was detected the following March in Rock Creek.

Further indication of out-of-basin fish use came from genetic analyses performed on tissue samples (fin clips) collected during fish sampling procedures (2016-17) for a subset of $O$. mykiss throughout the study area. Results were consistent with past efforts from 2008-12 (Matala and others, 2017), indicating the population is a mix of Rock Creek, MCR DPS (out of Rock Creek subbasin), and outside of the MCR DPS (that is, Upper Columbia River, Snake River) populations. The distinctiveness of Rock Creek O. mykiss among populations of the Columbia River Basin was evaluated using genetic stock identification and the same methodology used previously (Matala and others, 2017). A total of 343 samples were successfully genotyped; however, generally there was very low confidence in assignments, indicating a high degree of mixing. Genetic stock population assignments were about 1 percent Quartz Creek, 19 percent Rock Creek, 15 percent MCR, and 65 percent outside of the MCR DPS populations.

\section{Discussion}

Rock Creek is an intermittent stream with low to no flow in summer and late autumn periods (June to November), nonetheless steelhead and Coho salmon continue to persist in this subbasin. Previous tagging efforts (2009-12) resulted in steelhead smolt-to-adult return rates ranging from 2.2 to 5.5 percent (Harvey, 2014; Harvey, 2015), within the target MCR DPS recovery goals of 2-6 percent (Comparative Survival Study Oversight Committee and Fish 
Passage Center Annual Report, 2018). Coho salmon were consistently present during 2016-17 in the subbasin, which is more than in previous years, lending evidence to the importance of intermittent streams for salmonid productivity (Wigington and others, 2006; Hwan and others, 2018; Obedzinski and others, 2018). In the past, survey efforts Coho salmon were only found in abundance during 2011 (Harvey 2014), and now are found in abundances similar to those of $O$. mykiss and in some pools and years have been the dominant species.

Salmonid pool abundance in Rock Creek subbasin varies by pool, year, and species. Generally, pool abundance density estimates for $O$. mykiss have decreased compared to past survey efforts (Harvey, 2014). It is difficult to make direct comparisons between pool density estimates during 2016-17 and those during 2011-12 as some methods differed (for example, pool surface area measurements, number of pools sampled, and pool locations). However, pool density estimates in Rock Creek were generally much higher during 2011 and 2012 (means of 0.87 and $1.04 \mathrm{fish} / \mathrm{m}^{2}$; range: $0-3.58 \mathrm{fish} / \mathrm{m}^{2}$ ) for age-0 O. mykiss compared to 2016 and 2017 (means of 0.24 and $0.21 \mathrm{fish} / \mathrm{m}^{2}$; range: $0-0.69 \mathrm{fish} / \mathrm{m}^{2}$ ). For age-1, O. mykiss pool density estimates for 2011 and 2012 were also higher (means of 0.19 and $0.22 \mathrm{fish} / \mathrm{m}^{2}$; range: $0-0.62$ fish $/ \mathrm{m}^{2}$ ) compared to 2016 and 2017 (means of 0.01 and $0.05 \mathrm{fish} / \mathrm{m}^{2}$; range: $0-0.12 \mathrm{fish} / \mathrm{m}^{2}$ ). The pattern was the same for Walaluuks Creek, with age-0 O. mykiss pool density for 2011 and 2012 (means of 2.62 and $1.03 \mathrm{fish} / \mathrm{m}^{2}$; range: $0.11-7.62 \mathrm{fish} / \mathrm{m}^{2}$ ) generally higher compared to 2016 and 2017 (means of 0.34 and $0.97 \mathrm{fish} / \mathrm{m}^{2}$; range: $0.12-2.30 \mathrm{fish} / \mathrm{m}^{2}$ ). For age- 1 O. mykiss in Walaluuks Creek, density estimates for 2011 and 2012 (means of 1.51 and $0.55 \mathrm{fish} / \mathrm{m}^{2}$; range: 0.11-4.81 fish $/ \mathrm{m}^{2}$ ) were higher than for 2016 and 2017 (means of 0.20 and $0.13 \mathrm{fish} / \mathrm{m}^{2}$; range: 0-0.47 fish $/ \mathrm{m}^{2}$ ). Columbia River runs and adult counts of steelhead at Columbia River dams have also decreased in the last 10 years (Columbia Basin Fishery Agencies and Tribes, 2019).

The abundance of Coho salmon in Rock Creek subbasin has been highly variable across years and pools. During sampling efforts from 2009 to 2012, they were only abundant during 2011 in which density estimates were calculated. These ranged from 0.01 to $1.25 \mathrm{fish} / \mathrm{m}^{2}$ with an average of $0.52 \mathrm{fish} / \mathrm{m}^{2}$ in Rock Creek and an average of $2.40 \mathrm{fish} / \mathrm{m}^{2}$ (range: $0.02-3.85 \mathrm{fish} / \mathrm{m}^{2}$ ) in Walaluuks Creek (Harvey, 2014). Coho salmon were consistently found throughout the Rock Creek subbasin in both 2016 and 2017 (abundance estimates averaged 0.82 and $0.24 \mathrm{fish} / \mathrm{m}^{2}$; range: 0-3.64 fish $/ \mathrm{m}^{2}$ ). In Walaluuks Creek density estimates for 2016 and 2017 were lower (means of 1.79 and $\left.0.42 \mathrm{fish} / \mathrm{m}^{2}\right)$ than during 2011, with a similar range $\left(0-3.68 \mathrm{fish} / \mathrm{m}^{2}\right)$. Columbia River adult Coho salmon counts have been more variable in the past 10 years, however higher adult counts at Bonneville and John Day dams occurred during 2009 and 2014 (Columbia Basin Fishery Agencies and Tribes, 2019), which correspond well with higher pool abundance of age-0's in Rock Creek during 2011 and 2016. During 2016, Coho salmon were often found in higher densities than O. mykiss in Walaluuks Creek (in pools downstream of rkm 4) and in pools from rkm 12-16 in Rock Creek (figs. 10 and 11).

Autumn juvenile abundance estimates provide evidence as to where salmonids are rearing and surviving over summer and which reaches are most productive or better suited to salmonids. Groundwater and spring water inputs are likely contributing to persistence of perennial pools and presence of salmonids in late summer/early autumn. Over summer survival is likely a limiting factor, as it is in other intermittent streams and can be influenced by seasonal drought with dry winters being harder than wet winters for fish survival through the summer (Hwan and Carlson, 2015; Hwan and others, 2018). This study does not directly measure over summer survival, or mortality of salmonids residing in pools that dry out completely. Very few salmonids (typically 0 or less than $0.1 \mathrm{fish} / \mathrm{m}^{2}$ ) were observed in pools downstream of $\mathrm{rkm} 5$ 
during 2016 and 2017 and in past study years (Harvey, 2014). In lower Rock Creek, temperatures are typically higher, frequently exceeding $22{ }^{\circ} \mathrm{C}$ during the months of July through September (Harvey, 2015). Pool temperature is likely a strong factor in over summer survival and abundance; however, steelhead have persisted through summer in pools that exceeded $22{ }^{\circ} \mathrm{C}$ but did not exceed $30^{\circ} \mathrm{C}$ in Rock Creek and in a southern California stream (Sloat and Osterback, 2013). Stream temperatures influence fish physiology and bioenergetics, effecting growth, swimming efficiency, and fish behavior (Myrick and Cech, 2000; Beauchamp and others, 2007; Beer and Anderson, 2011; Sloat and Osterback, 2013). Other factors likely influencing survival and abundance are pool isolation (no surface flow), number of days pool has been isolated, surface area, pool depth, instream flow, instream cover, fish density, and predation ([piscivorous and non-piscivorous predators]; Hwan and Carlson, 2015; Woelfle-Erskine and others, 2017). Typically, more non-salmonids, with higher thermal tolerances are found in Rock Creek pools downstream of rkm 5, including smallmouth bass, northern pikeminnow, redside shiners, and bridgelip suckers. Both smallmouth bass and northern pikeminnow are predators of juvenile salmonids.

In other sections of Rock Creek, more year to year variability in species abundance have been observed, with the highest variability from rkm 5 to about rkm 13 (confluence Walaluuks Creek). Upper Rock Creek (upstream of rkm 13) has consistent presence of salmonids, but some pools near rkm 14 and 16 appear to favor Coho salmon, where upstream (rkm 20) pools are dominated by $O$. mykiss. In Walaluuks Creek, salmonids have been consistently found, up to rkm 4.5 and upstream of about $\mathrm{rkm} 7$, indicating overall suitable habitat quality in pools sampled; however, species abundance varies by year. Much of the habitat between rkm 4.5 and 7 goes dry during summer low flow periods. Some years pools are dominated by Coho salmon (2016) and other years O. mykiss (2017). Generally, O. mykiss are more abundant than Coho salmon in the upper sections of Walaluuks Creek. Some of the variability across years is likely explained by the ocean conditions and species run strength across years. Fewer Coho salmon redds and adults have been observed in upper Walaluuks Creek, than in lower Walaluuks or mainstem Rock Creek (Harvey, 2015). However, during 2014, more Coho salmon redds were observed in lower Walaluuks Creek, which coincides with the higher Coho salmon juvenile densities observed in 2016 (Harvey, 2015). Redd distributions can influence juvenile distribution and abundance (Foldvik and others, 2010).

An increase in Coho salmon reintroduction programs both upstream in the Yakima River Basin, Upper Columbia River Basin, and downstream in the Klickitat River Basin likely contributes to the increase in adult spawners and redd abundance as potential strays into Rock Creek (Galbreath and others, 2014). Evidence of this is the recent adult Coho salmon detected in Rock Creek that originated from Prosser Hatchery. Reintroduced Coho salmon have shown to be successful in immediate productivity and establishment towards naturalized origin populations in new spawning habitat (Galbreath and others, 2014; Campbell and others, 2017; Liermann and others, 2017).

Survival estimates for juvenile $O$. mykiss in Rock Creek were generated similarly to past years. However, the modeling approach was different between the study periods. For 2009 to 2012, release groups were combined across years for reach survival, and $O$. mykiss apparent survival (overwinter) was estimated to the first downstream detection sites for fish released in Rock Creek (28 percent), in Walaluuks Creek (25 percent), and Rock Creek downstream of RCS (39 percent). During 2016 and 2017, survival estimates were modeled by release group, year, and reach and overwinter survival results (range 36-55 percent) were higher for all, except fish 
released downstream of RCS in 2016 (21 percent; table 9). Detection efficiencies for $O$. mykiss at detection arrays were similar across study periods. Reach survival for the RCL reach was 91 percent for the 2009-12 study period and ranged from 67 to 100 percent for release groups by year (2016-17). The estimate of 100 percent survival was an effect of the model not being able to converge on an estimate, rather than a true 100 percent survival for that release group. For JDA, reach survival was 86 percent during 2009-12 and ranged from 54 to 90 percent for fish released upstream of RCS and 41 to 76 percent for fish released downstream of RCS during 2016-17 for release groups. The JDA estimates are not very precise, since fewer fish are detected at John Day Dam and detection probability at this site is also low.

Coho salmon survival estimates were generated for the first time during 2016-17. Rock Creek overwinter survival estimates were within the range of other tributary survival estimates for age-0 Coho salmon (Ebersole and others, 2009; Roni and others, 2012; Manhard and others, 2018). Generally, apparent overwinter survival estimates for Coho salmon released upstream of RCS were higher (35-66 percent; table 10) than those of O. mykiss (table 9). One reason for lower apparent survival for $O$. mykiss is the consideration that resident $O$. mykiss, which are not observed migrating, are modeled as mortalities. Differences in over summer survival has been noted in previous studies between Coho salmon and $O$. mykiss and may be associated with differences in habitat preferences or behavior (Hwan and others, 2018). During 2016, both $O$. mykiss and Coho salmon released downstream of RCS had relatively low apparent overwinter survival (21 percent). While during 2017, apparent overwinter survival for fish released in this same reach was 55 percent for $O$. mykiss and 40 percent for Coho salmon. Previous to the 2016 tagging efforts, Washington had been in an extended period of drought which may have had a cumulative effect of survival heading into winter. Another factor may have been an increased parasite burden in lower Rock Creek, subsequent to the prolonged drought conditions. Black spot infestations (a Neascus-type trematode parasite; Cairns and others, 2005) were more frequently observed in lower Rock Creek pools which were isolated. Ebersole and others, (2006) reported that portions of watersheds with high levels of black spot infestations also were areas of poor overwinter survival for Coho salmon. Black spot infestations were observed for both Coho salmon and $O$. mykiss as well as some bridgelip suckers and were more frequent in lower Rock Creek than elsewhere.

Reach survival for RCL was generally higher for Coho salmon (90-97 percent) than for O. mykiss for fish released upstream of RCS. For JDA, reach survival ranged from 63 to 86 percent for fish released upstream of RCS and from 53 to 100 percent for fish released downstream of RCS. Again, the 100 percent survival estimate is a modeling effect of either very few fish detections or lack of convergence of the model to estimate survival. Precision for this reach is also low due to fewer fish detections. Coho salmon survival have a year and release group effect, where fish tagged and released in upper Rock Creek had better survival than fish released in Walaluuks Creek during the same year and survival was higher for release groups in 2017 than for 2016. This pattern was the same for fish migrating through the RCL reach survival; however, the individual estimates were more similar across years. Increased apparent overwinter survival with juvenile Coho salmon body size has been documented in previous studies (Quinn and Peterson 1996; Ebersole and others, 2006). This may explain some of the lower survival observed during 2016, which had a higher proportion of tagged fish under $80 \mathrm{~mm}$ (fig. 1-2).

Some species differences in survival could be due to species habitat preferences (Woelfle-Erskine and others, 2017; Hwan and others, 2018). Coho salmon were commonly 
found in pools with beaver activity. Coho salmon abundance may also have an impact on the current population of O. mykiss. However, Temple and others (2017) found that O. mykiss abundance, average size, condition, and growth were not reduced following reintroduction of Coho salmon. With only two years of survival estimates with both species present throughout the study area determining trends in survival is not possible.

Although we have increased our understanding of bridgelip suckers in Rock Creek subbasin, still very little is known about this population. The majority of bridgelip suckers are distributed within mainstem Rock Creek and primarily located in the lower and middle pools, downstream of rkm 16. The distribution of bridgelip suckers could be influenced by a higher thermal preference (Huff and others, 2005) and thus are more abundant lower in the system. Multiple age classes were observed within Rock Creek. Survival estimates were not modeled, due to few PTIS detections; however, apparent survival was 20 and 25 percent for 2016 and 2017. Adding an additional PTIS array close to the mouth and or the point at which Rock Creek is inundated by the Columbia River would likely increase detections for bridgelip suckers tagged downstream of RCL. During 2017, the majority of bridgelip suckers were tagged downstream of RCL and were not detected again. It is unknown as to whether these fish did not survive or moved out of Rock Creek.

Although it is concerning that abundance estimates for $O$. mykiss have decreased between study periods, survival rates are comparable to other sustained populations and Rock Creek salmonids continue to persist. O. mykiss have a high thermal tolerance within Pacific Salmonids and are considered good colonizers in that straying is a common life history behavior. Maintaining biological and spatial diversity is a key component of species conservation biology (Hank and Williams 2012), combined with monitoring of populations to understand metapopulation-level contributions (Fullerton and others, 2016). Although the most recent genetic analysis indicates a high degree of out-of-basin influence to the Rock Creek population, a Rock Creek component still exists. The persistence of this population may be a result of genetic or behavioral adaptation to existing environmental conditions. Even though Rock Creek has intermittent flow throughout the year, there remains persistent suitable habitat in reaches throughout the subbasin. Pacific salmonids show a high degree of plasticity in adapting to changing environmental conditions (Crozier and others, 2008; Crozier and Hutchings 2014) and intermittent streams are proving to be important for salmon productivity (Wigington and others, 2006; Woelfle-Erskine and others, 2017; Hwan and others, 2018).

It is difficult to manage populations and make resource decisions in a changing climate with potential for decreased population abundance and increasing marginal habitat, such as in a system like Rock Creek. Still the Rock Creek O. mykiss population are culturally important to tribes and biologically contributing to the recovery, abundance, and resiliency of the MCR DPS. Limiting factors still exist with low streamflows, prolonged periods of pool isolation, temperatures above optimal thresholds for longer duration, and expansion of non-native fish in the subbasin. Protection of current suitable habitat should be a priority; however, protection alone is not likely to be sufficient to conserve salmonid populations (Wade and others, 2013). Restoring streamflow regimes, increasing connectivity, reducing water withdrawals, and restoring floodplain and riparian function may be able to ameliorate temperature increases and base flow decreases (Beechie and others, 2013). Instream rehabilitation such as addition of structure may also ameliorate temperature increases and may provide additional cover and refuge for fish. 


\section{Adaptive Management and Lessons Learned}

Although our baseline information on salmonids and bridgelip sucker distribution, abundance, and survival in Rock Creek is enhanced, data gaps still exist. More information could be gained with installation and operation of a PTIS at the mouth or inundated portion of Rock Creek by the Columbia River. This would likely improve our survival estimates by improving overall detection efficiencies. Furthermore, it would provide more information on timing of stream entry by adults which could be correlated to flow timing and run timing. This could provide insight into behavioral adaptations on migration timing of salmonids to spawn in this subbasin. For example, there is the potential for delayed timing of entry for Coho salmon in order to spawn in Rock Creek. Plasticity of salmonids to adapt to new habitats and changing environmental conditions is still not well known. It could also provide further information about kelt life history behavior for $O$. mykiss. Additional reach survival estimates would be possible for the lower reach (RCL to the mouth) and potential better understanding of losses which may be occurring in the backwater area and mainstem Columbia River to JDA. Bridgelip sucker information on movement could also be improved with a downstream PTIS. Furthermore, we can refine locations for restoration work, by estimating time spent in reaches for rearing and potentially over-summer survival based on autumn abundance in lower RCL, RCL, and upstream of RCS reaches. Survival estimates and smolt-to-adult return estimates could be improved by increasing the number of fish tagged. With increased fish tagged numbers further analyses could be performed to model survival and fish abundance with additional covariates (that is, habitat variables, fish size, etc.). Additional funding would be necessary to accomplish these improvements.

Intermittent streams, which go dry during low-flow periods, but have persistent isolated pools are proving to be important and productive for salmonid habitat. Key limiting factors to productivity include thermal and hydrologic regimes, which are influenced by watershed characteristics, land-use practices, increased human groundwater development, and populationspecific life histories and adaptations to local environmental factors. Local adaptation, life history diversity, spatial diversity, and plasticity of salmonids influence resiliency to climate effects and overall population persistence. Increasing our understanding of which populations persist, how they persist, and what can be done to maintain and increase resiliency under harsh conditions will inform resource manager decisions on recovery strategies and potentially important habitat types (that is, intermittent streams) for ESA listed salmonids and other culturally significant species.

\section{Acknowledgments}

We would like to thank the private landowners and lessees and Yakama Nation that allowed access to their lands for habitat surveys, fish sampling, and maintenance of the PIT Tag Interrogation Systems. We thank the Yakama Nation for partnering with USGS to conduct this work and Bonneville Power Administration for funding. We thank Andrew Matala for genetic analyses. We owe the success of this project to the work of the many Yakama Nation and USGS fisheries technicians and volunteers. 


\section{References Cited}

Beauchamp, D.A., Cross, A.D., Armstrong, J.L., Myers, K.W., Moss, J.H., Boldt, J.L., and Haldorson, L.J., 2007, Bioenergetic responses by Pacific salmon to climate and ecosystem variation: Bull. North Pac. Anadromous Fish Comm., v. 4, p. 257-269.

Beechie, T., Imaki, H., Greene, J., Wade, A., Wu, H., Pess, G., Roni, P., Kimball, J., Stanford, J., Kiffney, P., and Mantua, N., 2013, Restoring salmon habitat for a changing climate: River Research and Applications, v. 29, p. 939-960.

Beer, W.N., and Anderson, J.J., 2011, Sensitivity of juvenile salmonid growth to future climate trends: River Research and Applications, v. 27, no. 5, p. 663-669, https://doi.org/10.1002/rra.1390.

Bogan, M.T., Boersma, K.S., and Lytle, D.A., 2013, Flow intermittency alters longitudinal patterns of invertebrate diversity and assemblage composition in an arid-land stream network: Freshwater Biology, v. 58, no. 5, p. 1016-1028, https://doi.org/10.1111/fwb.12105. Burnham, K.P., and Anderson, D.R., 2002, Model selection and inference-A practical information-theoretical approach 2nd ed.: New York, Springer-Verlag.

Cairns, M.A., Ebersole, J.L., Baker, J.P., Wigington, P.J., Jr., Lavigne, H.R., and Davis, S.M., 2005, Influence of summer stream temperatures on black spot infestation of juvenile Coho Salmon in the Oregon Coast Range: Transactions of the American Fisheries Society, v. 134, no. 6, p. 1471-1479, https://doi.org/10.1577/T04-151.1.

Campbell, N.R., Kamphaus, C., Murdoch, K., and Narum, S.R., 2017, Patterns of genomic variation in Coho salmon following reintroduction to the interior Columbia River: Ecology and Evolution, v. 2017, no. 23, p. 1-11, https://doi.org/10.1002/ece3.3492.

Chapman, D.G., 1951, Some properties of hypergeometric distribution with applications to zoological sample censuses: University of California Publications in Statistics, v. 1, p. 131159.

Columbia Basin Fishery Agencies and Tribes, 2019, FPC homepage: Columbia Basin Fishery Agencies and Tribes, accessed August 2018 at http://www.fpc.org/.

Comparative Survival Study Oversight Committee and Fish Passage Center, 2018, Comparative survival study of PIT-tagged spring/summer/fall Chinook, summer steelhead, and sockeye: 2018 Annual Report prepared for BPA Contract \#19960200.

Conley, W., 2015, Fluvial reconnaissance of Rock Creek and selected tributaries with implications for anadromous salmonid habitat management Rock Creek, Klickitat County, WA: Prepared for Bonneville Power Administration, Environment, Fish and Wildlife Program, Project Number: 2007-156-00, p. 130.

Cooch, E., and White, G., 2010 (9th ed.). Program MARK-A gentle introduction: phidot, accessed August 2018 at http://www.phidot.org/software/mark/docs/book/.

Crozier, L.G., Hendry, A.P., Lawson, P.W., Quinn, T.P., Mantua, N.J., Battin, J., Shaw, R.G., and Huey, R.B., 2008, Potential responses to climate change in organisms with complex life histories-Evolution and plasticity in Pacific salmon: Evolutionary Applications ISSN 17524571, p. 252-270, https://doi.org/10.1111/j.1752-4571.2008.00033.x.

Crozier, L.G., and Hutchings, J.A., 2014, Plastic and evolutionary responses to climate change in fish: Ecological Applications ISSN 1752-4571, p. 68-87, https://doi.org/10.1111/eva.12135.

Datry, T., Larned, S.T., and Tockner, K., 2014, Intermittent rivers-A challenge for freshwater ecology: Bioscience, v. 64, no. 3, p. 229-235, https://doi.org/10.1093/biosci/bit027.

Ebersole, J.L., Wigington, P.J., Jr., Baker, J.P., Cairns, M.A., Church, M.R., Hansen, B.P., Miller, B.A., LaVigne, H.R., Compton, J.E., and Leibowitz, S.G., 2006, Juvenile coho salmon 
growth and survival across stream network seasonal habitats: Transactions of the American Fisheries Society, v. 135, no. 6, p. 1681-1697, https://doi.org/10.1577/T05-144.1.

Ebersole, J.L., Colvin, M.E., Wigington, P.J., Jr., Leibowitz, S.G., Baker, J.P., Church, M.R., Compton, J.E., Miller, B.A., Cairns, M.A., Hansen, B.P., and La Vigne, H.R., 2009, Modeling stream network-scale variation in Coho Salmon overwinter survival and smolt size:

Transactions of the American Fisheries Society, v. 138, no. 3, p. 564-580, https://doi.org/10.1577/T08-047.1.

Foldvik, A., Gravbrot Finstad, A., and Einum, S., 2010, Relating juvenile spatial distribution to breeding patterns in anadromous salmonid populations: Journal of Animal Ecology, v. 79, no. 2, p. 501-509, https://doi.org/10.1111/j.1365-2656.2009.01652.x.

Fullerton, A.H., Anzalone, S., Moran, P., Van Doornik, D.M., Copeland, T., and Zabel, R.W., 2016, Setting spatial conservation priorities despite incomplete data for characterizing metapopulations: Ecological Applications, v. 26, no. 8, p. 2560-2580, https://doi.org/10.1002/eap.1411.

Galbreath, P.F., Bisbee, M.A., Jr., Dompier, D.W., Kamphaus, C.M., and Newsome, T.H., 2014, Extirpation and tribal reintroduction of Coho salmon to the interior Columbia River Basin: Fisheries (Bethesda, Md.), v. 39, no. 2, p. 77-87, https://doi.org/10.1080/03632415.2013.874526.

Hank, A.L., and Williams, J.E., 2012, Spreading the risk-Native trout management in a lesscertain future: North American Journal of Fisheries Management, v. 32, p. 687-401.

Harvey, Elaine, 2014, Rock Creek fish and habitat assessment for prioritization of restoration and protection actions: Bonneville Power Administration Annual Report, 2007-156-00.

Harvey, Elaine, 2015, Rock Creek fish and habitat assessment for prioritization of restoration and protection actions, 6/1/2013 - 12/31/2015: Bonneville Power Administration Annual Report, 2007-156-00.

Huff, D.D., Hubler, S.L., and Borisenko, A.N., 2005, Using field data to estimate the realized thermal niche of aquatic vertebrates: North American Journal of Fisheries Management, v. 25, no. 1, p. 346-360, https://doi.org/10.1577/M03-231.1.

Hwan, J.L., and Carlson, S.M., 2016, Fragmentation of an intermittent stream during seasonal drought - Intra-annual and interannual patterns and biological consequences: River Research and Applications, v. 32, no. 5, p. 856-870, https://doi.org/10.1002/rra.2907.

Hwan, J.L., Fernandez-Chacon, A., Buoro, M., and Carlson, S.M., 2018, Dry season survival of juvenile salmonids in an intermittent coastal stream: Canadian Journal of Fisheries and Aquatic Sciences, v. 75, no. 5, p. 746-758, https://doi.org/10.1139/cjfas-2017-0026.

Liermann, M., Pess, G., McHenry, M., McMillan, J., Elofson, M., Bennett, T., and Moses, R., 2017, Relocation and recolonization of Coho salmon Oncorhynchus kisutch in two tributaries to the Elwha River-Implications for management and monitoring: Transactions of the American Fisheries Society, v. 146, no. 5, https://doi.org/10.1080/00028487.2017.1317664.

Manhard, C.V., Som, N.A., Perry, R.W., Faukner, J.R., and Soto, T., 2018, Estimating freshwater productivity, overwinter survival, and migration patterns of Klamath River Coho Salmon: U.S. Fish and Wildlife Service, Arcata Fisheries Technical Report Number TR 201833.

Mantua, N., Tolver, I., and Hamlet, A., 2010, Climate change impacts on stream-flow extremes and summertime stream temperature and possible consequences for freshwater salmon habitat in Washington State: Climatic Change, v. 102, no. 1-2, p. 187-223, https://doi.org/10.1007/s10584-010-9845-2. 
May, C., Luce, C., Casola, J., Chang, M., Cuhaciyan, J., Dalton, M., Lowe, S., Morishima, G., Mote, P., Petersen, A., Roesch-McNally, G., and York, E., 2018, Northwest, in Reidmiller, D.R., Avery, C.W., Easterling, D.R., Kunkel, K.E., Lewis, K.L.M., Maycock, T.K., and Stewart, B.C., eds., Impacts, risks, and adaptation in the United States-Fourth National Climate Assessment v. II: Washington, D.C., U.S. Global Change Research Program, p. 10361100., doi:10.7930/NCA4.2018.CH24.

Mote, P., Snover, A.K., Capalbo, S., Eigenbrode, S.D., Glick, P., Littell, J., Raymondi, R., and Reeder, S., 2014, Ch. 21: Northwest. Climate Change Impacts in the United States: The Third National Climate Assessment, J. M. Melillo, Terese (T.C.) Richmond, and G. W. Yohe, Eds., U.S. Global Change Research Program, 487-513. doi:10.7930/J04Q7RWX.

National Marine Fisheries Service, 2009a, Middle Columbia River steelhead distinct population segment ESA Recovery Plan: Prepared by the National Marine Fisheries Service Northwest Region.

Myrick, C.A., and Cech, J.J., Jr., 2005, Effects of temperature on the growth, food consumption, and thermal tolerance of age-0 Nimbus-strain steelhead: North American Journal of Aquaculture, v. 67, no. 4, p. 324-330, https://doi.org/10.1577/A04-050.1.

National Oceanic and Atmospheric Administration, 2016, Endangered and threatened speciesFinal listing determinations for 10 distinct population segments of west coast steelhead: Federal Register, v. 71, no. 3, Rules and Regulations, p. 834-862.

National Marine Fisheries Service, 2009b, Recovery Plan for the Rock Creek Population of the Middle Columbia River Steelhead Distinct Population Segment. Prepared by the National Marine Fisheries Service Northwest Region, p. 102.

NMFS National Oceanic and Atmospheric Administration, 2016. 2016 5-Year Review: Summary and Evaluation of Middle Columbia River Steelhead, p. 63.

Northwest Power Planning Council, 2004, Lower Mid-Columbia mainstem including Rock Creek subbasin plan. Prepared for the Northwest Power Planning Council, p. 391.

Northwest Fisheries Science Center, 2015, Status review update for Pacific salmon and steelhead listed under the Endangered Species Act-Pacific Northwest. Northwest Fisheries Service.

Obedzinkski, M., Nossaman Pierce, S., Horton, G.E., and Deitch, M.J., 2018, Effects of flowrelated variables on oversummer survival of juvenile Coho salmon in intermittent streams: Transactions of the American Fisheries Society, v. 147, no. 3, p. 588-605 https://doi.org/10.1002/tafs.10057.

Quinn, T.P., and Peterson, N.P., 1996, The influence of habitat complexity and fish size on overwinter survival and growth of individually marked juvenile coho salmon (Oncorhynchus kisutch) in Big Beef Creek, Washington: Canadian Journal of Fisheries and Aquatic Sciences, v. 53, no. 7, p. 1555-1564 https://doi.org/10.1139/f96-092.

R Development Core Team, (2008). R: A language and environment for statistical computing. R Foundation for Statistical Computing, Vienna, Austria, ISBN 3-900051-07-0, accessed August 2018 at http://www.R-project.org.

Raymond, C.L., Peterson, D.L., and Rochefort, R.M., eds., 2014, Climate change vulnerability and adaptation in the North Cascades region, Washington. Gen. Tech. Rep. PNW-GTR-892: Portland, OR, U.S. Department of Agriculture, Forest Service, Pacific Northwest Research Station, 279 p. https://doi.org/10.2737/PNW-GTR-892

Roni, P., Bennett, T., Holland, R., Pess, G., Hanson, K., Moses, R., McHenry, M., Ehinger, W., and Walter, J., 2012, Factors affecting migration timing, growth, and survival of juvenile Coho 
Salmon in two coastal Washington watersheds: Transactions of the American Fisheries Society, v. 141, no. 4, p. 890-906 https://doi.org/10.1080/00028487.2012.675895.

Sloat, M.R., and Osterback, K.A., 2013, Maximum stream temperature and the occurrence, abundance, and behavior of steelhead trout (Oncorhynchus mykiss) in a southern California stream: Canadian Journal of Fisheries and Aquatic Sciences, v. 70, no. 1, p. 64-73 https://doi.org/10.1139/cjfas-2012-0228.

Temple, G.M., and Pearsons, T.N., 2007, Electrofishing - Backpack and drift boat, in Johnson, D.H., Shrier, B.M., O'Neal, J.S., Knutzen, J.A., Augerot, X., O'Neil, T.A., and Pearsons, T.N., eds., Salmonid field protocols handbook-Techniques for assessing status and trends in salmon and trout populations: Bethesda, Maryland, American Fisheries Society, p. 95-132.

Temple, G.M., Newsome, T., Webster, T.D., and Coil, S.W., 2017, Evaluation of Rainbow Trout abundance, biomass, and condition following Coho Salmon reintroduction in Taneum Creek, Washington: Northwest Science, v. 91, no. 1, p. 54-68 https://doi.org/10.3955/046.091.0107.

Wade, A.A., Beechie, T.J., Fleishman, E., Mantua, N.J., Huan, W., Kimball, J.S., Stoms, D.M., and Stanford, J.A., 2013, Steelhead vulnerability to climate change in the Pacific Northwest: Journal of Applied Ecology, v. 50, p. 1093-1104 https://doi.org/10.1111/1365-2664.12137.

Waples, R.S., Beechie, T.J., and Pess, G.R., 2009, Evolutionary history, habitat disturbance regimes, and anthropogenic changes - What do these mean for resilience of Pacific salmon populations?: Ecology and Society, v. 14, no. 1, p. 3 https://doi.org/10.5751/ES-02626140103.

Wigington, P.J., Jr., Ebersole, J.L., Colvin, M.E., Leibowitz, S.G., Miller, B., Hansen, B., Lavigne, H.R., White, D., Baker, J.R., Church, M.R., Brooks, J.R., Cairns, M.A., and Compton, J.E., 2006, Coho Salmon dependence on intermittent streams: Frontiers in Ecology and the Environment, v. 4, no. 10, p. 513-518 https://doi.org/10.1890/15409295(2006)4[513:CSDOIS]2.0.CO;2.

Woelfle-Erskine, C., Larsen, L.G., and Carlson, S.M., 2017, Abiotic habitat thresholds for salmonid oversummer survival in intermittent streams: Ecosphere, v. 8, no. 2, p. e01645 https://doi.org/10.1002/ecs2.1645. 


\section{Appendix 1. Length Frequency Histograms}

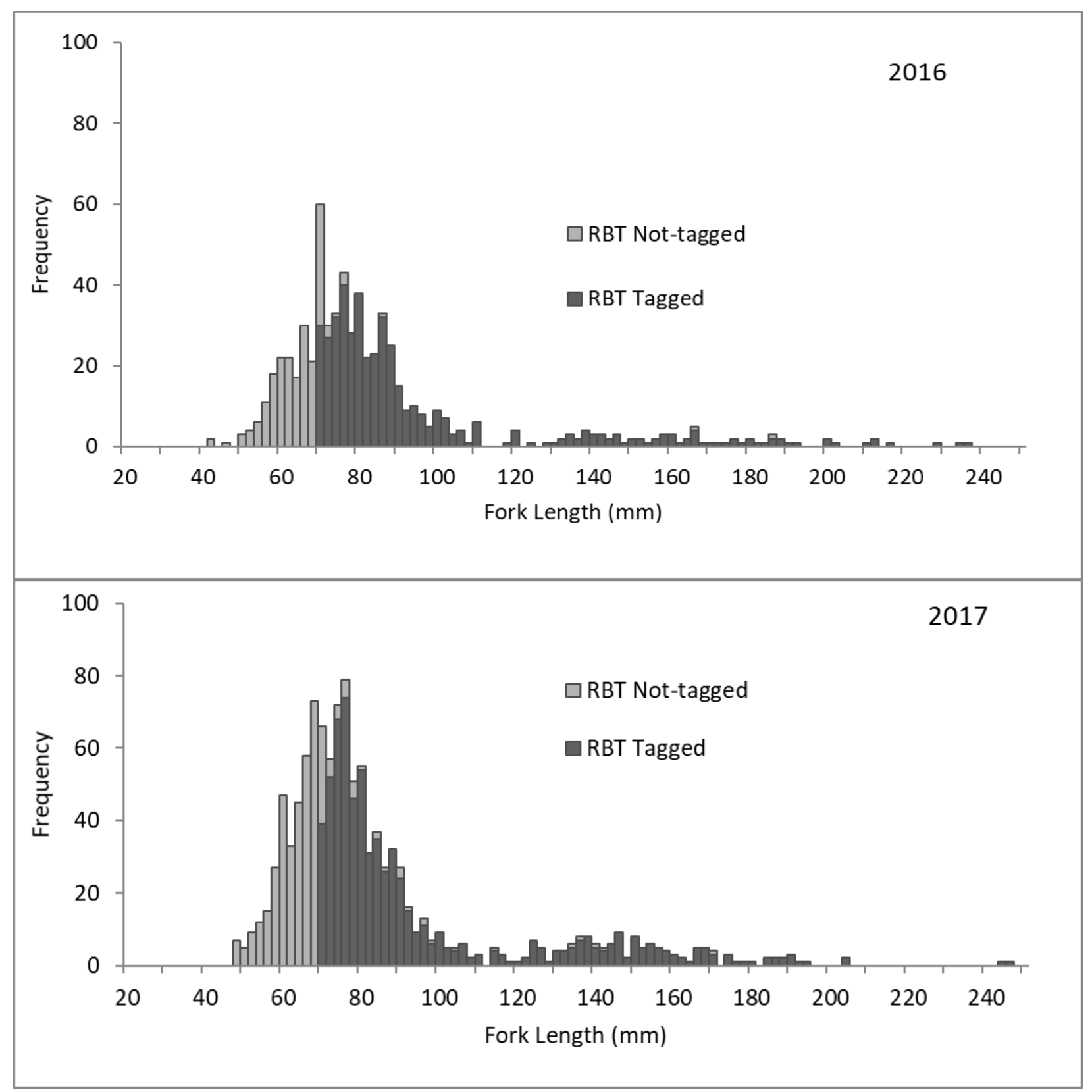

Figure 1-1. Length frequency histograms for Oncorhynchus mykiss (RBT) sampled in Rock and Walaluuks Creeks, Washington in 2016 (upper panel) and 2017 (lower panel). 


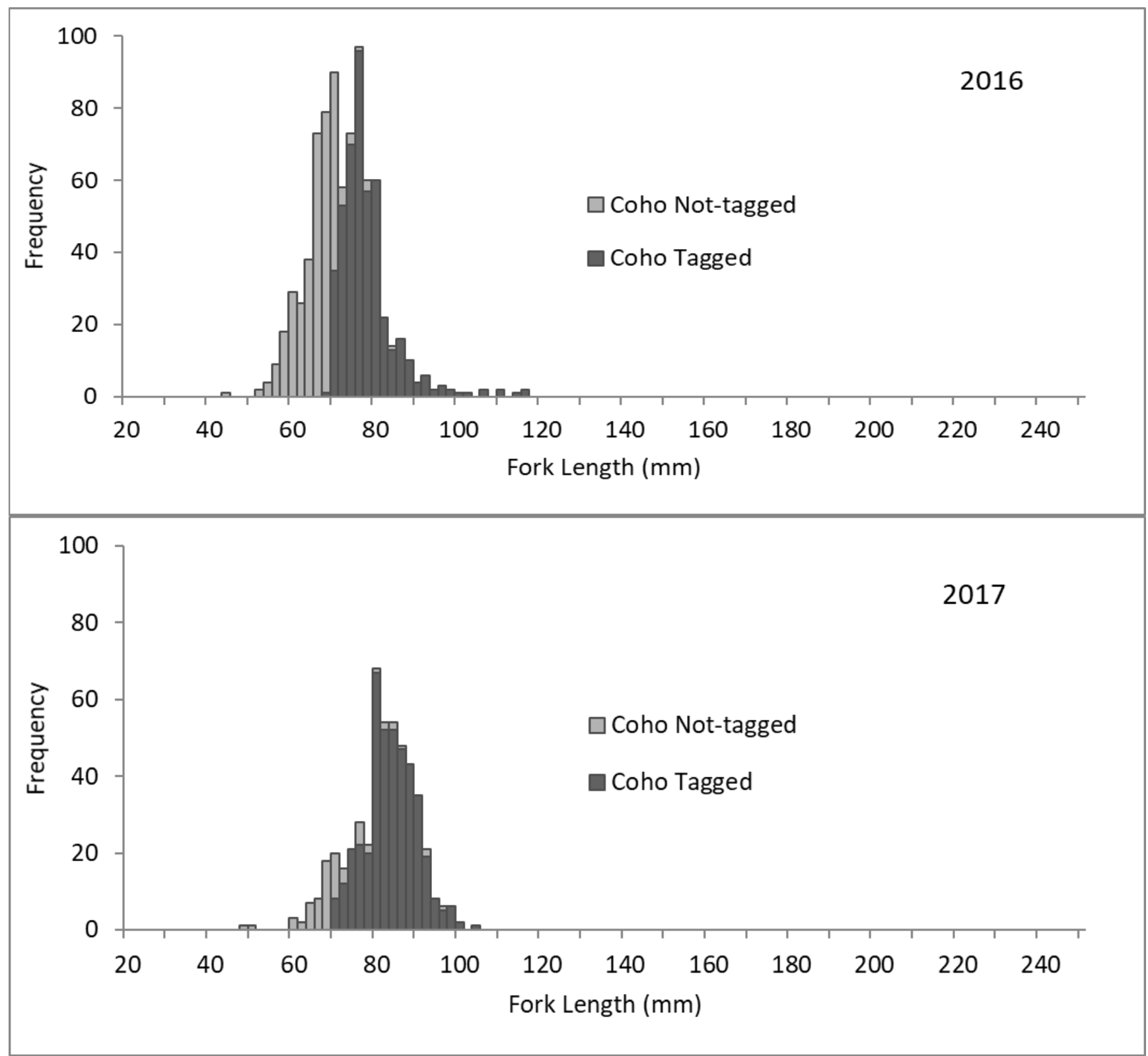

Figure 1-2. Length frequency histograms for Coho salmon (Oncorhynchus kisutch) sampled in Rock Creek and Walaluuks Creek, Washington in 2016 (upper panel) and 2017 (lower panel). 


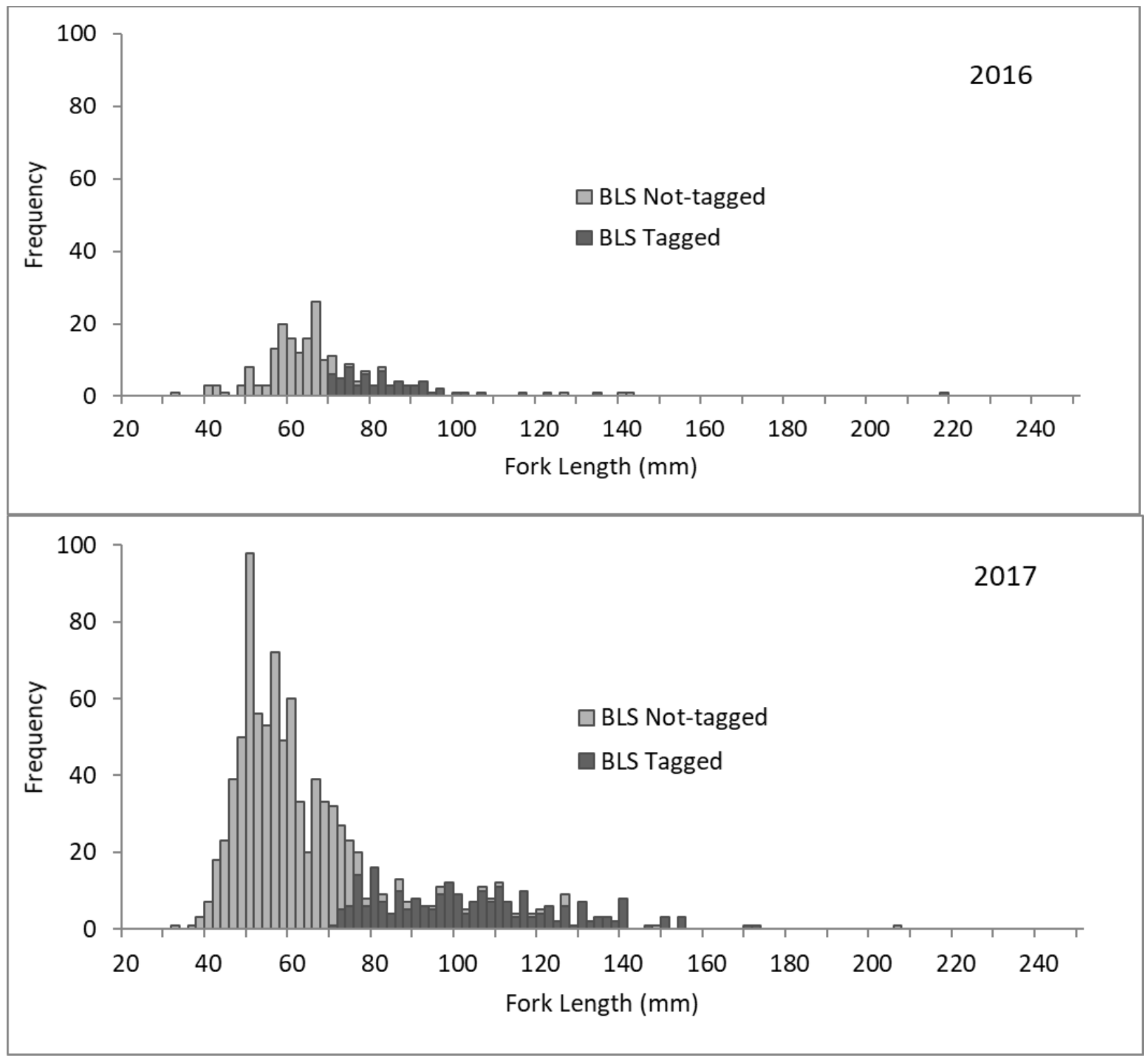

Figure 1-3. Length frequency histograms for bridgelip suckers (BLS, Catostomus columbianus) sampled in Rock Creek and Walaluuks Creek, Washington in 2016 (upper panel) and 2017 (lower panel). 


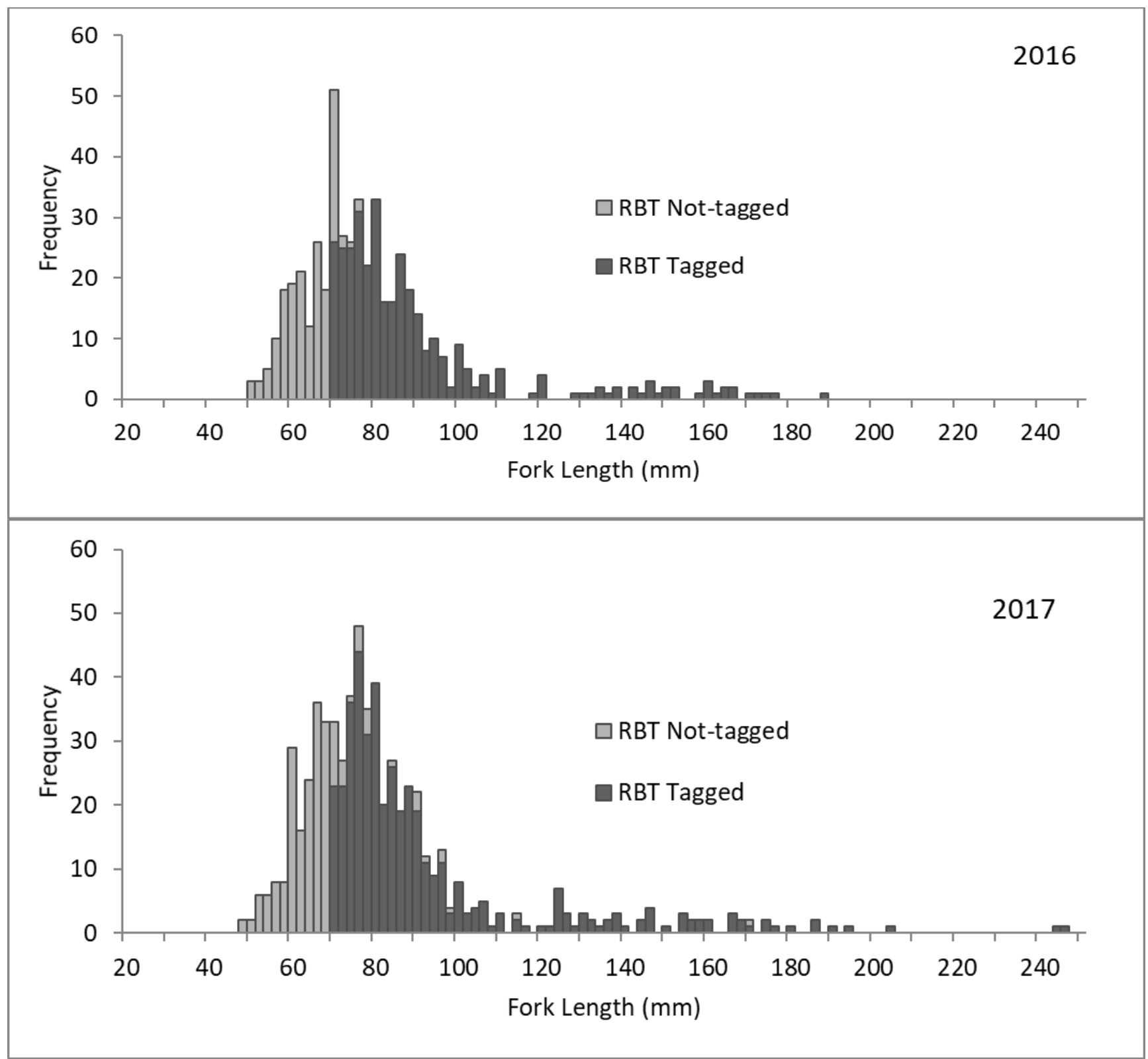

Figure 1-4. Length frequency histograms for Oncorhynchus mykiss (RBT) sampled in Rock Creek, Washington, in 2016 (upper panel) and 2017 (lower panel). 


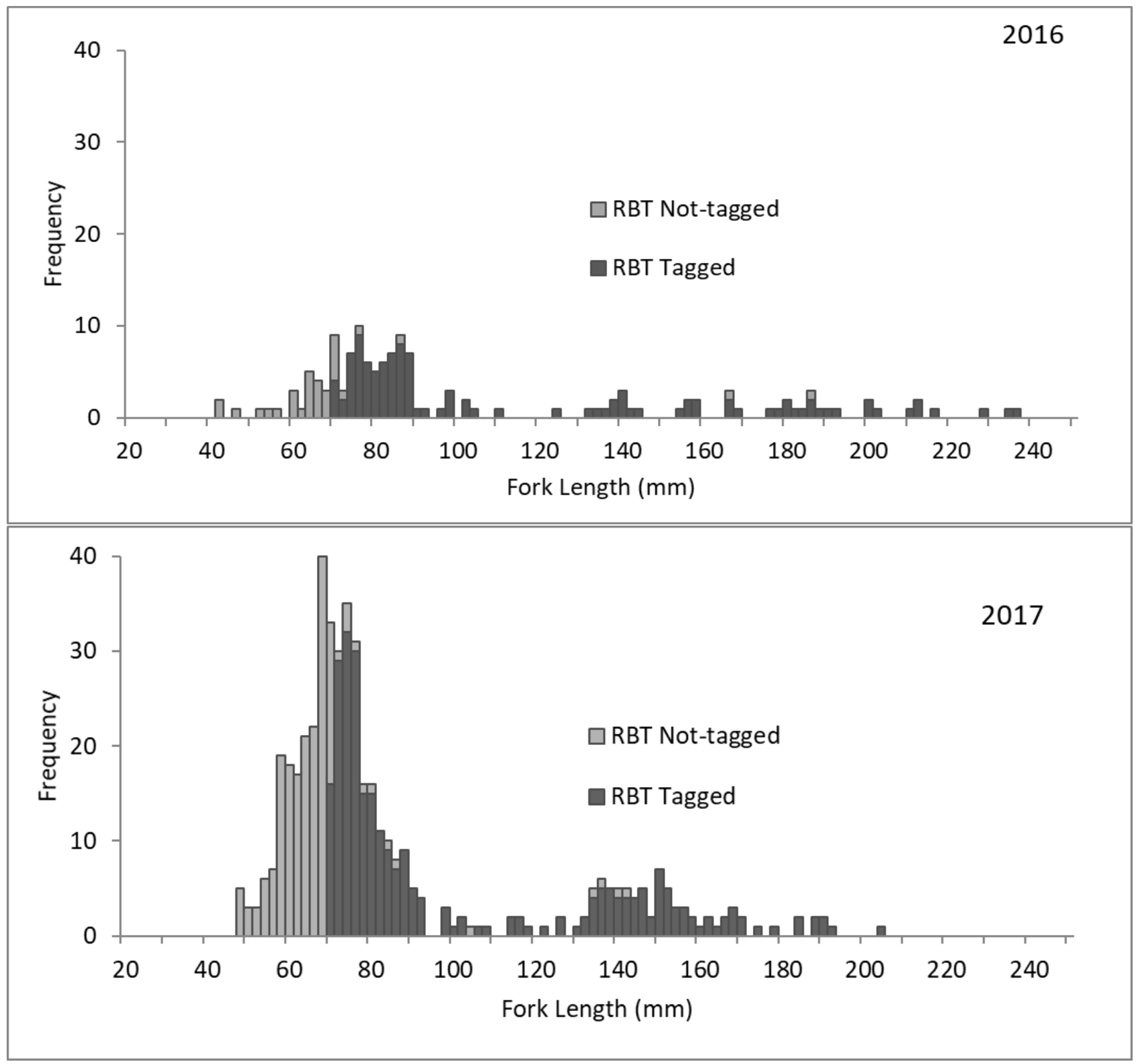

Figure 1-5. Length frequency histograms for Oncorhynchus mykiss (RBT) sampled in Walaluuks Creek, Washington, in 2016 (upper panel) and 2017 (lower panel). 


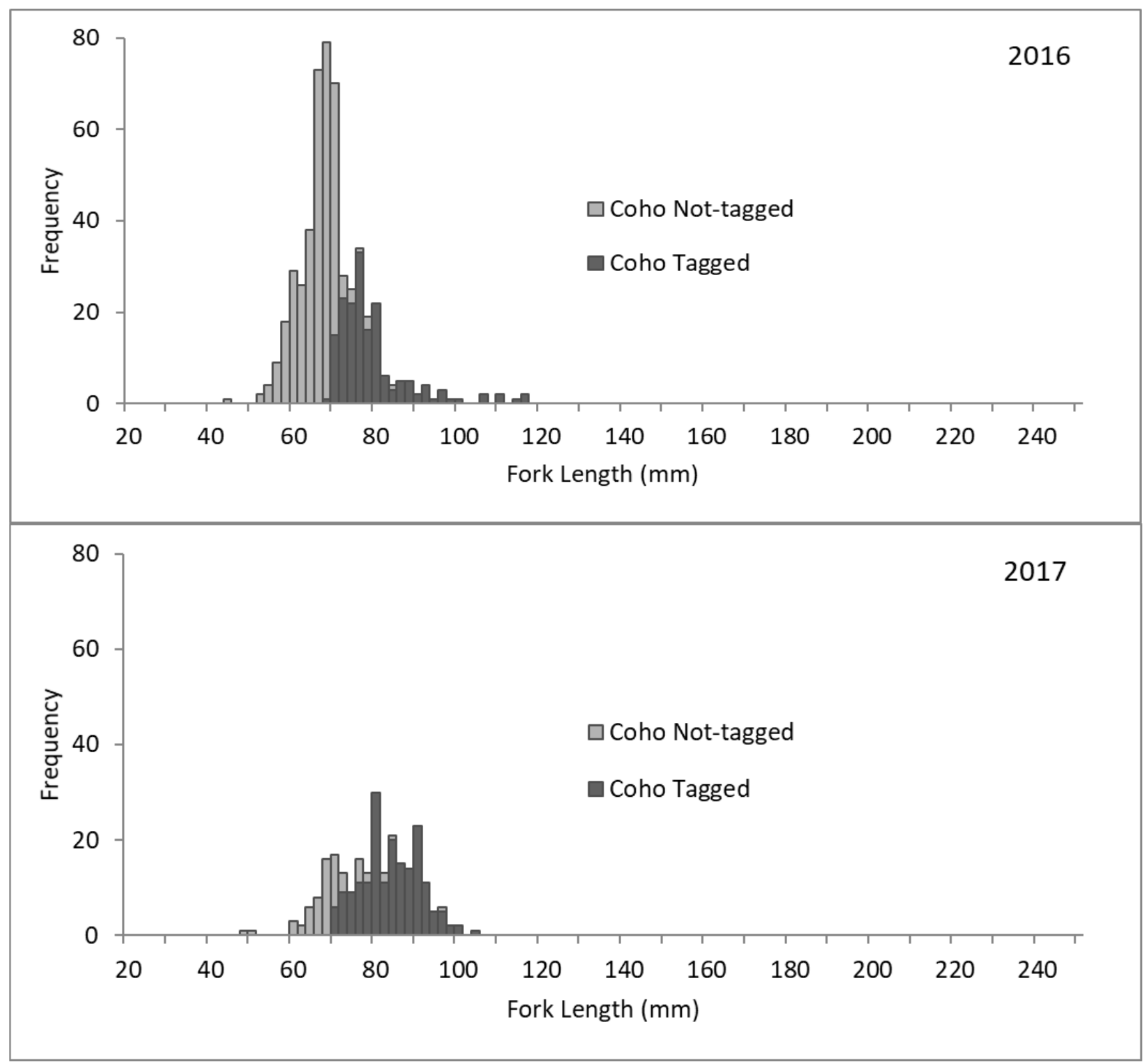

Figure 1-6. Length frequency histograms for Coho salmon (Oncorhynchus kisutch) sampled in Rock Creek, Washington, in 2016 (upper panel) and 2017 (lower panel). 


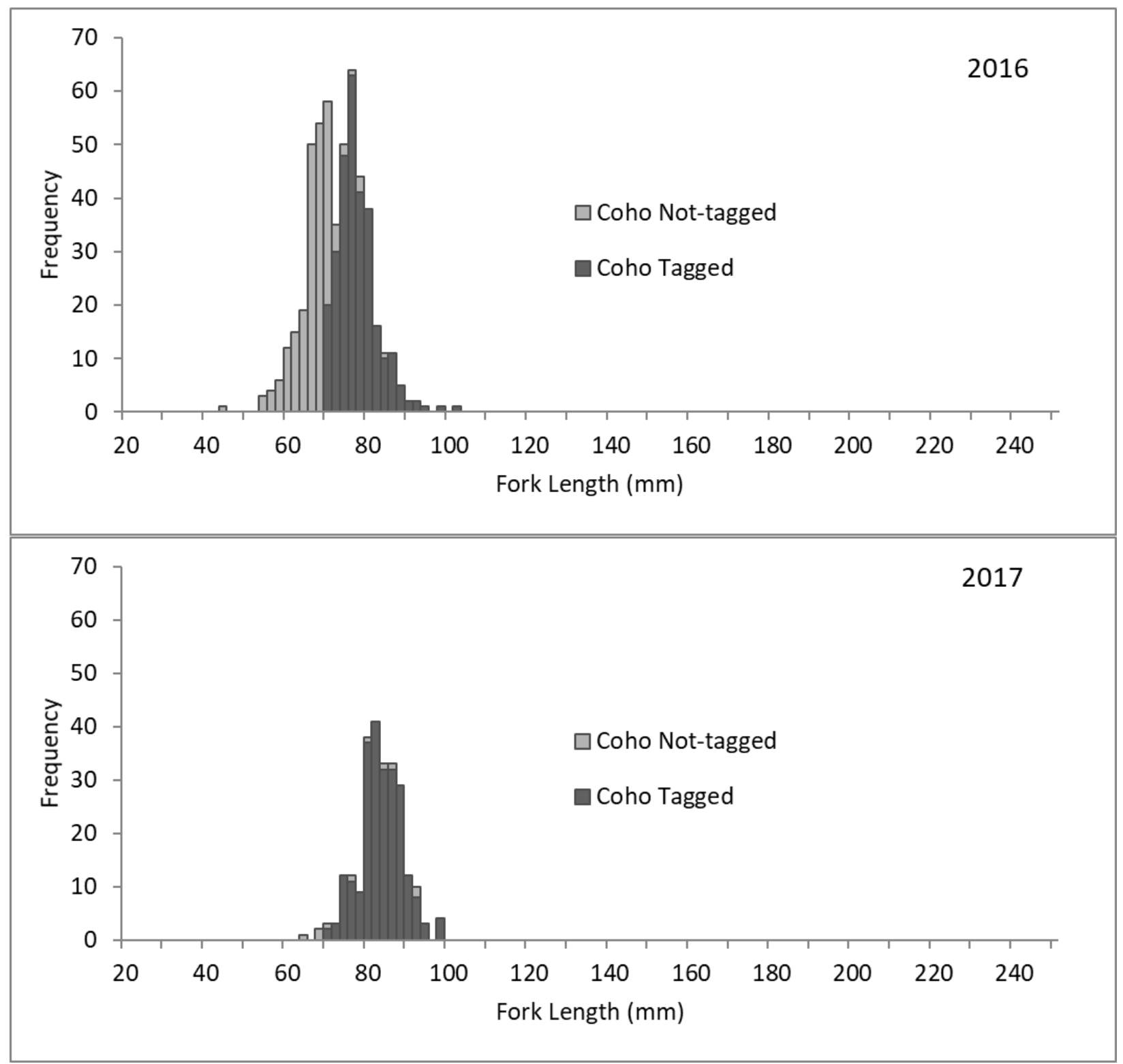

Figure 1-7. Length frequency histograms for Coho salmon (Oncorhynchus kisutch) sampled in Walaluuks Creek, Washington, in 2016 (upper panel) and 2017 (lower panel). 


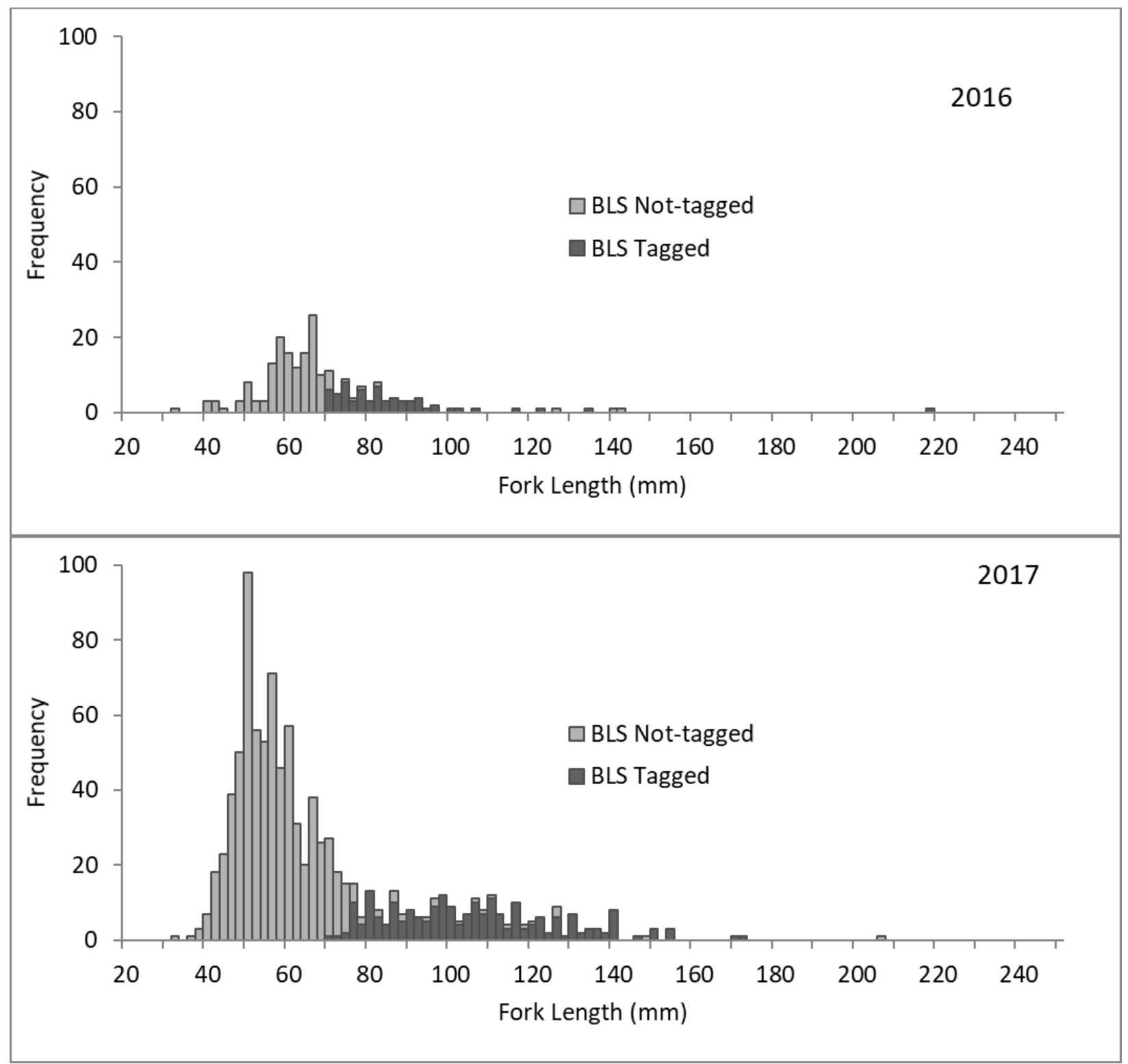

Figure 1-8. Length frequency histograms for bridgelip suckers (BLS; Catostomus columbianus) sampled in Rock Creek, Washington, in 2016 (upper panel) and 2017 (lower panel). 


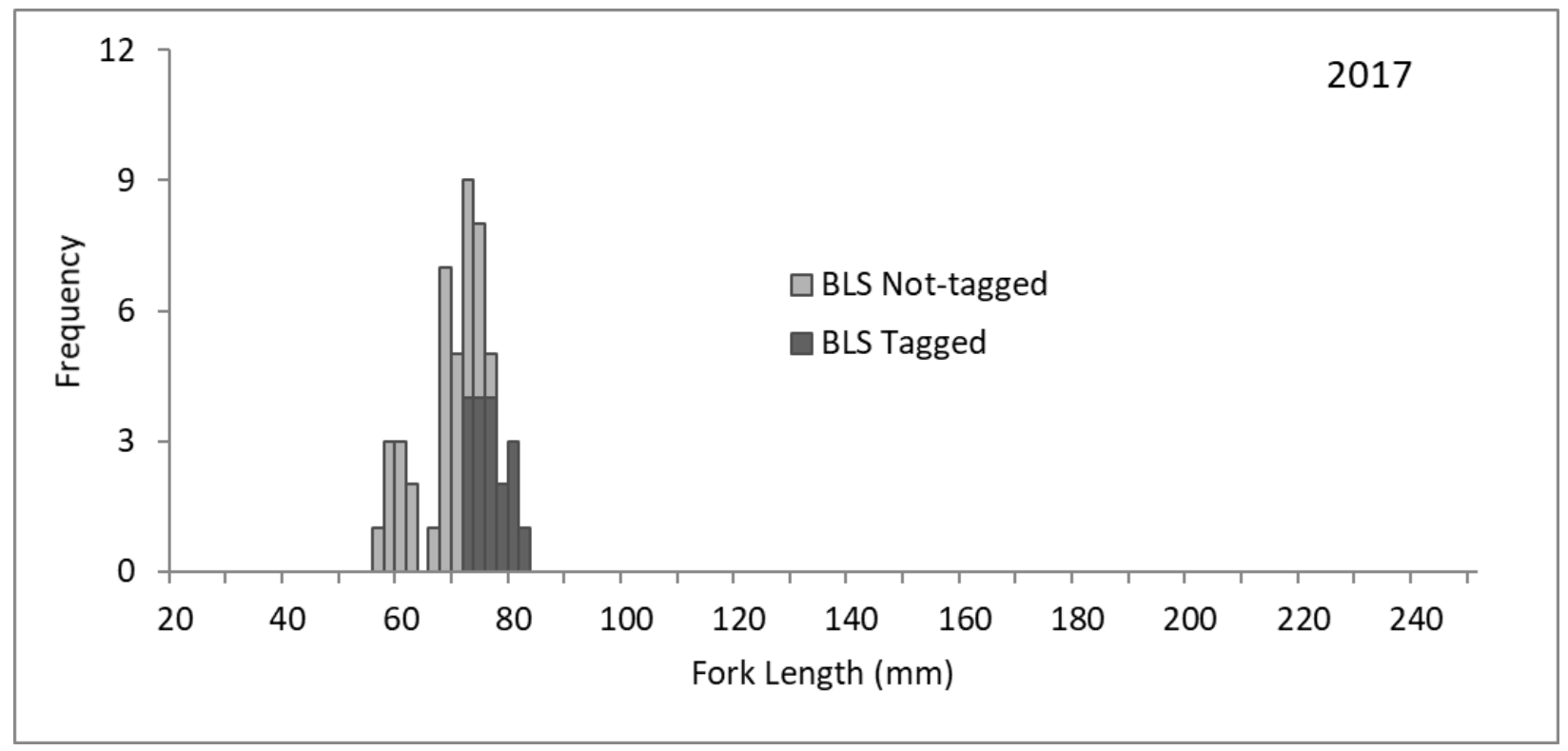

Figure 1-9. Length frequency histograms for bridgelip suckers (BLS; Catostomus columbianus) sampled in Walaluuks Creek, Washington, in 2017. 


\section{Appendix 2. Weight-Length Relationships}

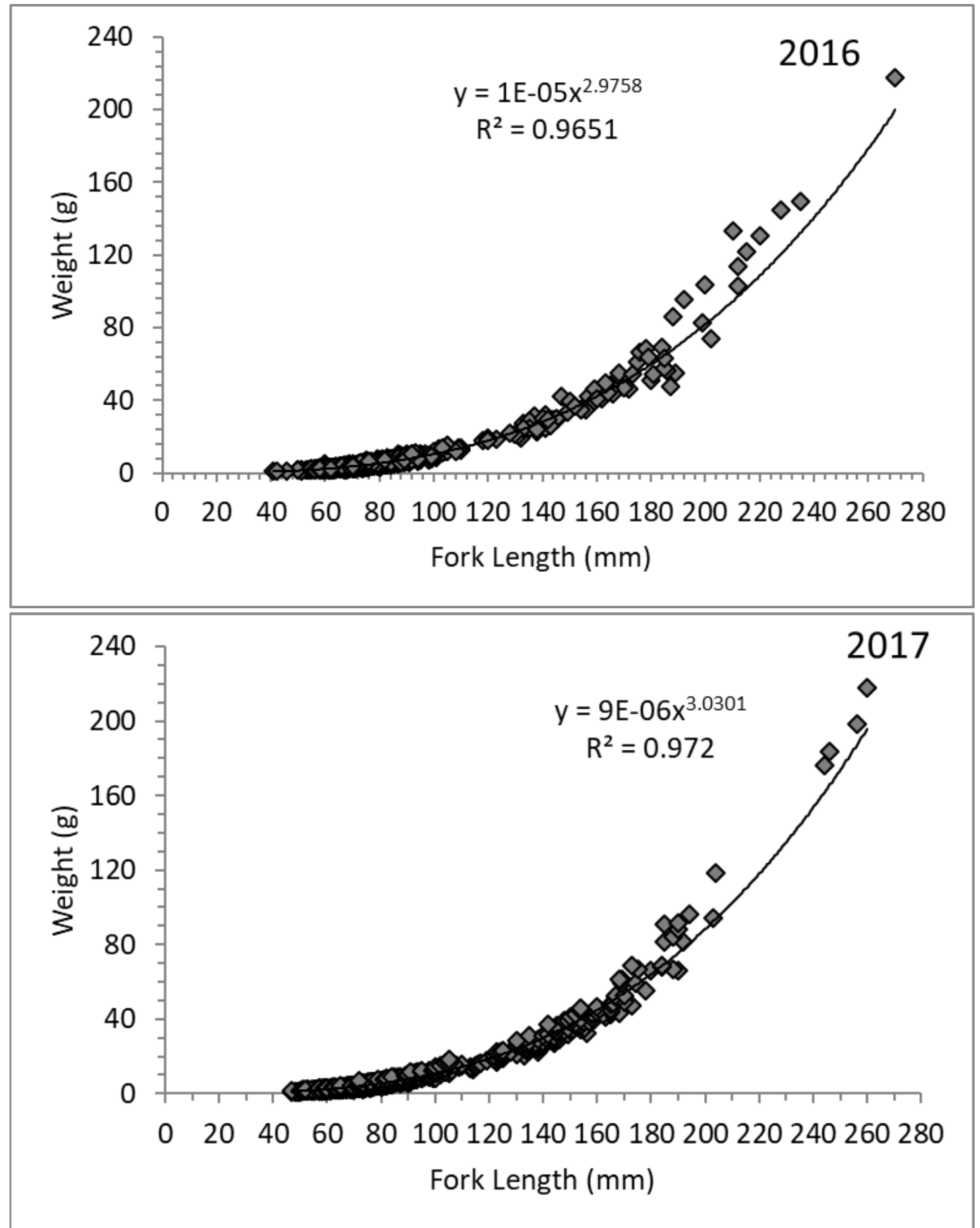

Figure 2-1. Length-weight relationship for Oncorhynchus mykiss captured in Rock and Walaluuks Creeks, Washington, during electrofishing sample efforts fall of 2016 (upper panel) and 2017 (lower panel). 


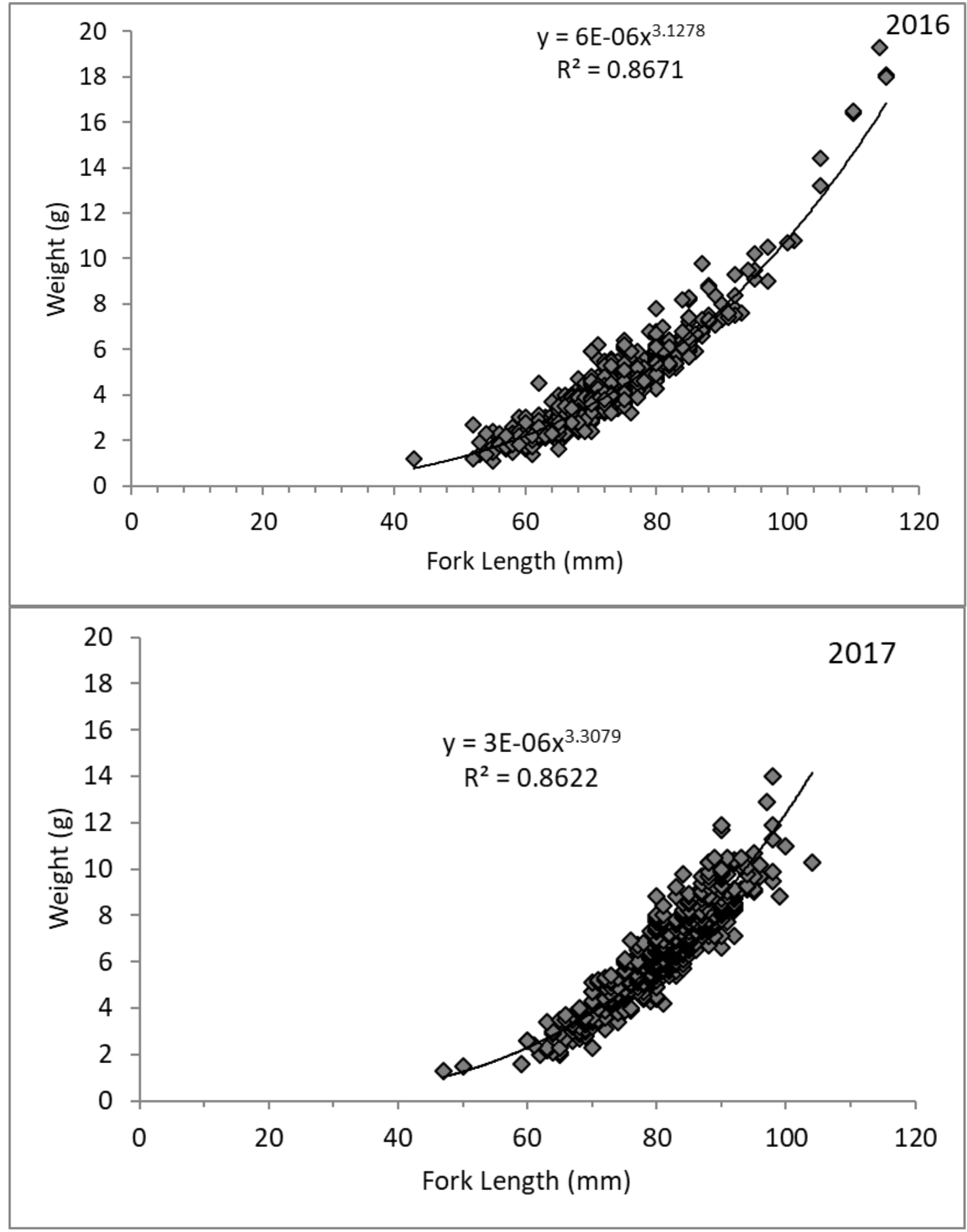

Figure 2-2. Length-weight relationship for Coho salmon (Oncorhynchus kisutch) captured in Rock and Walaluuks Creeks, Washington, during electrofishing sample efforts in autumn 2016 and 2017. 


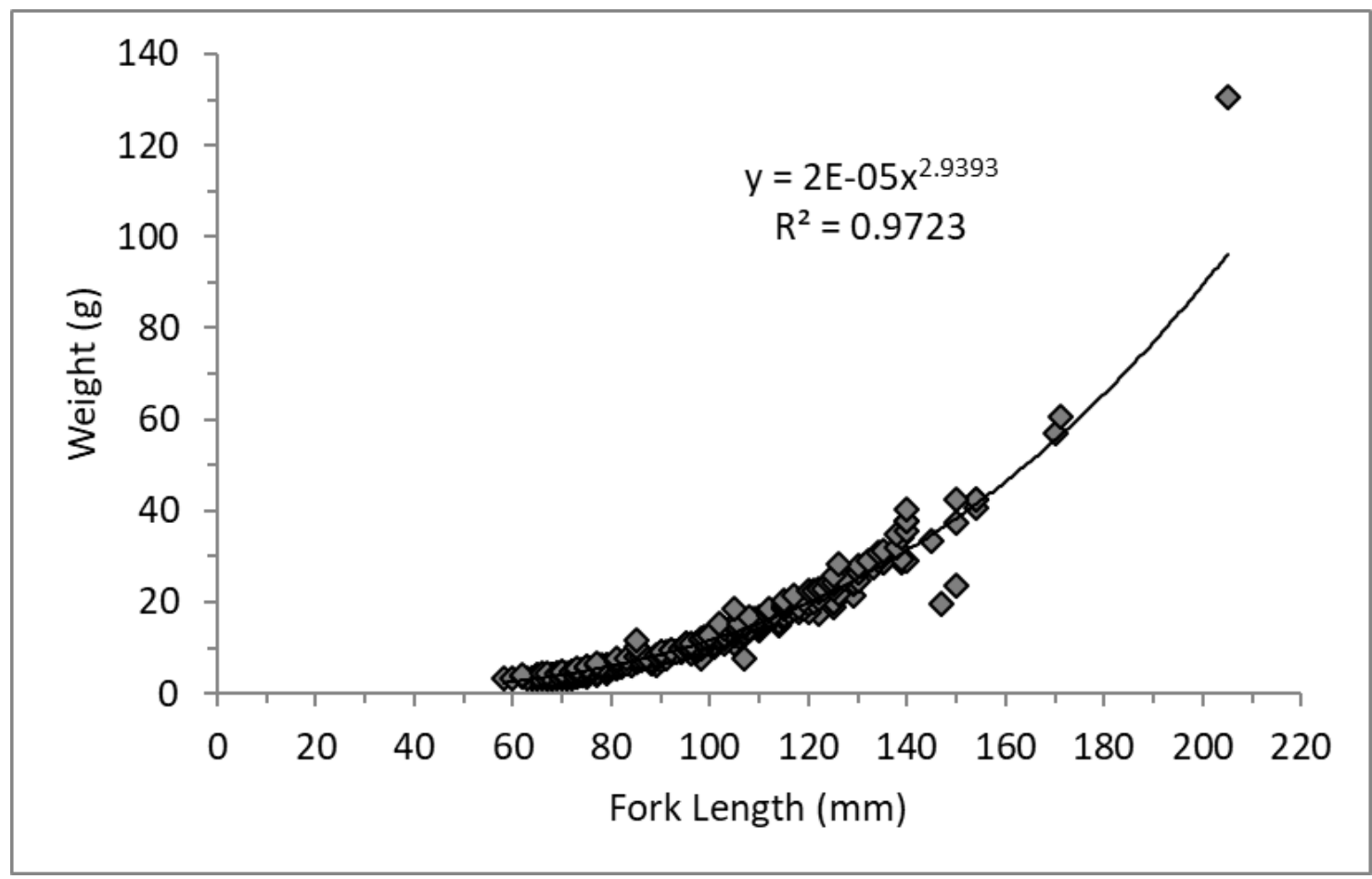

Figure 2-3. Length-weight relationship for bridgelip suckers (Catostomus columbianus) captured in Rock and Walaluuks Creeks, Washington, during electrofishing sampling in autumn 2017. 


\section{Appendix 3. PIT-Tag Interrogation System Operation Log}

Table 3-1. Summary of dates for PIT Tag Interrogation System Array operations for sites RCS and RCL on Rock Creek, Washington.

[RCL, Rock Creek Longhouse; RCS, Rock Creek Squaw; rkm, river kilometer]

\begin{tabular}{lll}
\hline \multicolumn{1}{c}{ Dates } & \multicolumn{2}{c}{ Operating/Not operating } \\
\hline $6 / 14 / 16-10 / 28 / 16$ & Not operating & RCL (rkm 5) \\
$10 / 28 / 16-6 / 27 / 17$ & Operating & Deactivated for summer due to intermittent flow \\
$6 / 27 / 17-10 / 26 / 17$ & Not operating & Fish monitoring \\
$10 / 26 / 17-12 / 19 / 17$ & Operating & Deactivated for summer-intermittent flow \\
$12 / 19 / 17-12 / 22 / 17$ & Not operating & Fish monitoring \\
$12 / 22 / 17-6 / 27 / 18$ & Operating & Equipment failure \\
$6 / 27 / 18-10 / 24 / 18$ & Not operating & Fish monitoring \\
$10 / 24 / 18$ & Operating & Deactivated for summer-intermittent flow \\
& & Activated for fish monitoring \\
\hline $5 / 29 / 16-11 / 08 / 16$ & Not operating & RCS (rkm 14) \\
$11 / 08 / 16-2 / 22 / 17$ & Operating & Deactivated for summer due to intermittent flow \\
$2 / 22 / 17-3 / 09 / 17$ & Not operating & Fish monitoring \\
$3 / 09 / 17-6 / 26 / 17$ & Operating & Equipment failure \\
$6 / 26 / 17-10 / 26 / 17$ & Not operating & Fish monitoring \\
$10 / 26 / 17-6 / 27 / 18$ & Operating & Deactivated for summer due to intermittent flow \\
$6 / 27 / 18-10 / 24 / 18$ & Not operating & Fish monitoring \\
$10 / 24 / 18$ & Operating & Deactivated for summer due to intermittent flow \\
& & Activated for fish monitoring \\
\hline
\end{tabular}



Publishing support provided by the U.S. Geological Survey Science Publishing Network, Tacoma Publishing Service Center

For more information concerning the research in this report, contact the Director, Western Fisheries Research Center

U.S. Geological Survey 6505 NE 65th Street

Seattle, Washington 98115-5016

https://www.usgs.gov/centers/wfrc 


\section{寍}

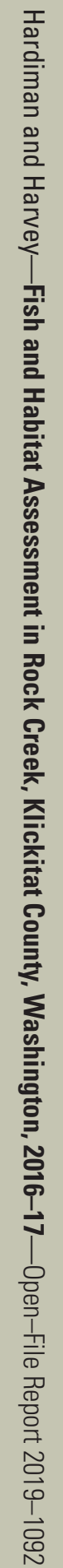

